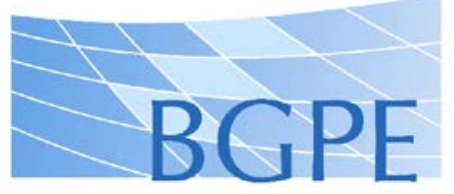

BGPE Discussion Paper

No. 168

\title{
How Deep is Your Love? A Quantitative Spatial Analysis of the Transatlantic Trade Partnership
}

\author{
Oliver Krebs \\ Michael Pflüger
}

December 2016

\author{
ISSN 1863-5733 \\ Editor: Prof. Regina T. Riphahn, Ph.D. \\ Friedrich-Alexander-University Erlangen-Nuremberg \\ (c) Oliver Krebs, Michael Pflüger
}




\title{
How Deep is Your Love? A Quantitative Spatial Analysis
}

\section{of the Transatlantic Trade Partnership*}

\author{
Oliver Krebs* \\ University of Würzburg
}

\author{
Michael Pflüger ${ }^{* *}$ \\ University of Würzburg \\ DIW Berlin and IZA
}

December 22, 2016

\begin{abstract}
This paper explores the effects of trade liberalization envisioned in a Transatlantic Trade and Investment Partnership (TTIP) between the United States and the European Union. We use a new quantitative spatial trade model with consumptive and productive uses of land and inputoutput linkages. Our calibration draws mainly on the World Input Output Database (WIOD). The eventual outcome of the negotiations is uncertain. Tariffs in EU-US-trade are already very low, however, so that an agreement will have a major impact only by eliminating non-tariff barriers. These are extremely hard to quantify. We address these uncertainties by considering a corridor of trade liberalization paths and by providing numerous robustness checks. We find that even with ambitious liberalization, real income gains within a TTIP are in the range of up to $0.46 \%$ for most countries. The effect on outside countries is often negative, and even smaller. Taking land into account scales down the welfare effects quite strongly. Interestingly, we find that all German counties derive unambiguous welfare gains even though the model allows for negative terms-of-trade effects, in principle. Our analysis also implies that in order to arrive at the same welfare gains as under a TTIP, a multilateral liberalization would have to be much more ambitious for the US than for the EU.
\end{abstract}

JEL-Classification: F11, F16, R12, R13

Keywords: $\quad$ international trade and trade policy, factor mobility, intermediate inputs, sectoral interrelations, transatlantic trade, TTIP

* This is a major revision of IZA DP 9021. We thank Daniel Baumgarten, Kristian Behrens, Toker Doganoglu, Jonathan Eaton, Carsten Eckel, Hartmut Egger, Hans Fehr, Gabriel Felbermayr, Martin Gornig, Inga Heiland, Borris Hirsch, Sebastian Krautheim, Yasusada Murata, Kurt Schmidheiny, Claus Schnabel, Gaaitzen de Vries, Matthias Wrede, Jens Wrona and conference and seminar participants in Basel (SGVS), Düsseldorf (EGIT), Geneva (DEGIT), Ghent (SMYE), Göttingen, Lisbon (UEA-ERSA), Münster (VfS), Nuremberg, Paris (ETSG), Regensburg and Würzburg for helpful comments. Financial support from Deutsche Forschungsgemeinschaft (DFG) through PF 360/7-1 is gratefully acknowledged.

* Oliver Krebs, Faculty of Economics, University of Würzburg, Sanderring 2, 97070 Würzburg, Germany, Tel (Fax) +49 (0) 931 31-83996 (87025), e-mail: oliver.krebs@uni-wuerzburg.de.

** Corresponding author: Michael Pflüger, Faculty of Economics, University of Würzburg, Sanderring 2, 97070 Würzburg, Germany, Tel (Fax) +49 (0) 931 31-83673 (87025), e-mail: michael.pflueger@uni-wuerzburg.de. 


\section{Introduction}

This paper explores the possible quantitative consequences of trade liberalization envisioned in a Transatlantic Trade and Investment Partnership (TTIP) between the United States and the European Union for these trading partners and for other countries in the world trading system. The prospect of a transatlantic trade deal has stimulated heated public and academic debates ever since the negotiations started in the summer of 2013 (Bhagwati 2013). Progress at the negotiating table was slow and limited even after fifteen rounds of negotiations conducted until October 2016. The year 2016 saw rising resistance against a TTIP in a number of countries of the European Union and opposition against trade deals from the candidates for the American Presidency which ranged from soft to hostile. Consequently, political observers conjectured already before the American elections that a TTIP would not be concluded for years to come. ${ }^{1}$ The trade agenda of the new president of the United States is yet unclear and so is his ultimate approach towards transatlantic trade. These trade ties, in any case, are not fraught from his part with allegations of unfair competition as those that he has levied against China or Mexico. ${ }^{2}$ Moreover, industry organizations such as the German American Chamber of Commerce continue to lobby strongly for a TTIP and its leading members are reported to deem the prospect of a continuation of the TTIP-talks 'fairly optimistic' after a 'constructive talk' in December 2016 between the German Chancellor Angela Merkel and the American president-elect, Donald Trump. ${ }^{3}$ Finally, the idea of a Free Trade Area spanning the Atlantic Ocean has existed at least since the 1990 Transatlantic Declaration and the 1995 New Transatlantic Agenda and even though it has been subject to politico-economic cycles, the idea has recurred time and again (Langhammer et al. 2002). One reason for this is certainly that a TTIP would be of paramount importance for the global economy as it involves economies accounting for almost one half of global value added and one third of world trade (Hamilton and Quinlan 2014).

These observations highlight that it is important to understand what is at stake in a potential transatlantic trade deal. Several issues have shaped the recent debate. One issue is that bilateral agreements such as a TTIP may have negative effects on outsiders and undermine the global trading system (Bagwell et al. 2016; Bhagwati et al. 2014; Panagariya 2013). An arguably much more controversial issue has derived from the fact that the tariffs prevailing in EU-US trade are

\footnotetext{
${ }^{1}$ See the coverage in the Economist April 30, 2016 ('Trading Places') and September 15, 2016 ('Why Germans are protesting free trade').

${ }^{2}$ The president-elect reinforced his resistance against a Trans-Pacific (trade) Partnership (TPP) with 11 countries around the Pacific Rim and against the North-American Free Trade Agreement (NAFTA) established in 1994 in recent rhetoric. See the Economist December 10, 2016 ('Dealing with Donald').

${ }^{3}$ See the press coverage by Frankfurter Allgemeine Zeitung, December 7, 2016.
} 
already very low (on average less than $3 \%$ for manufactures and slightly more for agricultural products), so that significant liberalization can only be achieved by tackling non-tariff barriers and by moving towards 'deep integration' (Lawrence 1996). These non-tariff barriers involve numerous choices and issues in fields such as product and production standards, environmental regulation, health and safety, labor standards, cultural diversity and investor state dispute settlement procedures. The snag with these regulations is that they reflect a variety of concerns which range from pure protectionism to non-protectionist objectives involving domestic policies which are entirely legitimate and even sanctioned by WTO-law if exerted in a nondiscriminatory fashion. These considerations make it clear that the issues and effects of a TTIP are multifaceted. One important research line concerns the justification and the trade and welfare effects of various domestic policies and regulations that prevail in the EU and in the US for non-protectionist motives such as market failures due to externalities, market power, or asymmetric information. ${ }^{4}$

This paper contributes to another line of research, the exploration of the quantitative consequences of transatlantic trade liberalization. We analyze the effects on welfare and its constituent parts (wages, prices and land rents) in the countries of the European Union, the United States and countries outside this agreement. Our key focus is to take a spatial perspective. More specifically, we are the first to explore trade liberalization under a TTIP with a deliberately simple and transparent medium-sized new quantitative spatial trade model. We highlight the role of space in three ways. First, we include land both as a factor of production and as a consumption good (land for housing). Second, since public and academic awareness of within-country effects of shifts in the global economy has grown recently, we trace the effects of trade liberalization down to local labor markets, exemplified by German counties. ${ }^{5}$ Third, we complement this analysis by offering a long-run perspective where we allow labor to be mobile within Germany or the EU such that a spatial equilibrium obtains.

We use a new quantitative trade model in the spirit of Eaton and Kortum (2002). This new Ricardian approach has already been applied to other instances of trade liberalization, in particular to NAFTA. ${ }^{6}$ More specifically, we use a version set up in Redding $(2014 ; 2016)$ which features land for housing and production and allows for labor mobility. We extend his

\footnotetext{
${ }^{4}$ We have contributed to this agenda elsewhere with analyses e.g. of the causes and effects of subsidies to market entry (Pflüger and Südekum 2013), the trade and welfare effects of environmental policies (Pflüger 2001) and the taxation of international trade (Haufler and Pflüger 2004, 2007).

${ }^{5}$ This awareness for the regional perspective is highlighted by Autor et al. (2013) and Caliendo et al. (2015).

${ }^{6}$ Caliendo and Parro (2015) use a version of this model to investigate NAFTA. Costinot and Rodriguez-Claré (2014) provide a lucid recent survey. See also our review of the literature below.
} 
model to comprise an arbitrary number of heterogeneous sectors with input-output linkages similar to Caliendo and Parro (2015). The trade pattern across locations follows the law of gravity. This model is static, so that the effects of trade liberalization uncovered in our analysis are static by nature and do not comprise follow-up effects associated with capital accumulation and dynamic growth effects. Moreover, the model's neglect of an intertemporal perspective implies that our analysis does not shed light on the evolution of trade surpluses and deficits. We proceed on the assumption that the aggregate trade balances are kept at their initial levels. ${ }^{7}$ The model also does not exhibit multinational firms so that our analysis does not embrace welfare effects associated with FDI. ${ }^{8}$ The perspective of the proximity-concentration tradeoff (Brainard 1997) implies that a TTIP's focus on trade liberalization shifts the odds in favor of the trade channel, however.

The provisions that a TTIP might eventually entail are highly uncertain, of course. ${ }^{9}$ This fact throws up a number of issues. Since tariffs in EU-US trade are already very low, such a deal will be of significance only by eliminating non-tariff barriers. Our strategy to address the extraordinary difficulties associated with the quantification of non-trade barriers and the uncertainties about the outcome of the EU-US negotiations is to consider a corridor of symmetric trade liberalization paths and to complement this with various asymmetric liberalization scenarios to check for robustness. Key for our empirical strategy is the 'exact hat algebra' developed by Dekle et al. (2007). It is widely used in new quantitative trade modelling because it allows to calibrate models extremely parsimoniously, getting rid of many exogenous parameters which will enter only indirectly through their effect on the observed ex-ante values of equilibrium variables (Costinot and Rodriguez-Claré 2014). In particular, we neither need to estimate substitution elasticities nor the locations' technology levels. Most importantly in the context of TTIP, we do not need the bilateral trade cost matrix and hence, we do not have to quantify tariff equivalents of the pre-existing non-tariff barriers, a task that has led to widely differing results (cf. section 3.4). Instead, we can rely on the fact that these parameters - notably trade barriers of any sort - are embedded in the observed ex-ante trade flows. We consider a range of conceivable across the board reductions of trade barriers resulting from the elimination

\footnotetext{
${ }^{7}$ Caliendo et al. (2014) abstract from the consumptive use of land and take a different path in their interregional analysis of the US-economy. They assume that part of the income that derives from the productive use of land and structures is distributed to a national portfolio and distributed across regions to match regional trade imbalances.

${ }^{8}$ An emergent literature introduces multinationals into quantitative trade models, see e.g. Ramondo and RodriguezClaré (2013), Arkolakis et al. (2014), Ramondo et al. (2014) and Alviarez (2015).

${ }^{9}$ The EU commission has started to publish summaries of the negotiation rounds in the fall of 2014 and has made its original proposal text available as well (see http://ec.europa.eu/trade/policy/in-focus/ttip/ for both). However, while the summary notes remain very general, the EU's proposal does obviously not allow to infer the rules of the final text. The consolidated chapters remain confidential to the general public.
} 
of frictions, tariffs and the harmonization of standards. To prevent that trade is subsidized in any sector, we calculate the Head-Ries-Index (Head and Mayer 2014) to establish an estimate of the upper threshold for this liberalization corridor (which we calculate at $9.97 \%$ ). This trade cost reduction would result in the strongest potential effects. We would like to make it clear that we take such a scenario as extreme since we view many of the prevailing non-tariff trade barriers in EU-US trade as grounded in legitimate domestic concerns such as those we have already alluded to.

The assumption of symmetric liberalization is arbitrary, of course. Our model and methodology are well-suited to address any liberalization scenario, however. We therefore complement our analysis with a large set of robustness checks which involve asymmetric liberalization paths in accordance with bottom-up and top-down estimates of the outcomes of the EU-US trade talks found in the literature and we also consider possible spillovers of TTIP to other countries (cf. section 3.4). We abstract from tariff revenues on the ground that if TTIP is to achieve significant liberalization it would have to involve primarily the reduction of non-tariff barriers. Abstracting from tariff revenue also allows us to avoid specifying how the loss in the budget of the EU induced by falling tariff incomes will affect individual member states. Our analysis thus captures the efficiency gains (the removal of production and consumption distortions) associated with the reduction of both non-tariff and tariff barriers but neglects that tariff income falls with the elimination of the remaining tariff barriers.

Our calibration of the model draws predominantly on the World Input Output Database (WIOD), which provides information for 44 countries and 56 industries (Timmer et al. 2015; 2016). Only few further data are needed. We use tariff data from the World Bank's WITS system to estimate the technological dispersion parameters of the Ricardian model. ILOSTAT data are needed for additional labor force information and data from the German federal and state statistical offices for our estimates for German counties. The only parameters that we have to take from outside sources are the consumption share of housing and the value added shares of land in production since serious data problems make it impossible to base these parameters on the WIOD and complementary databases as we explain in section 3.2.

We explore both a 'pure trade effect', which assumes that labor is immobile across locations and a 'labor mobility regime' within Germany and across the member countries of the European Union. Our results can be summarized as follows.

First, starting with the pure trade effect, even with the extreme trade barrier reduction of $9.97 \%$ between the US and the EU, real income gains are in the range of up to $0.46 \%$ for most TTIP- 
countries. The bilateral trade liberalization has negative welfare effects due to trade diversion on third countries such as China, Switzerland, Norway, Russia, Korea and Taiwan, but these are also typically small. The strongest winners and losers exhibit the closest ex-ante connections with the US or the EU as measured by initial spending shares. Even in our age of globalization these spending shares are small, which explains why the effects are limited.

Second, the welfare gains associated with transatlantic trade liberalization are overestimated if the consumptive use of land is not taken into account, since housing is intrinsically non-tradable and of considerable quantitative importance in spending. This effect is of the order of $10 \%$ and one reason, why we find smaller effects than other analyses. In pointing to the importance of land, our analysis also contributes to the general discussion of the sensitivity of the new quantitative trade models to auxiliary assumptions (see Costinot and Rodriguez-Claré 2014).

Third, industry effects (measured by production values) are mild in most parts of the EU and in the US. In Germany, to take one example machinery, transport equipment and wholesale obtain a small boost, telecommunications and transport activities shrink slightly. Ireland is an exception both in terms of the strong aggregate welfare gains and also in terms of the predicted industry effects which imply a strong boost for the financial sector, telecommunications, and chemical and pharmaceutical products. Robustness checks reveal that the Irish results largely hinge on liberalizing trade in services and the financial sector.

Fourth, we find that, despite their heterogeneity all German counties win even before allowing for labor mobility (which equalizes welfare). This also holds true for various asymmetric liberalization scenarios and is remarkable, because our model, in principle, allows for negative welfare effects associated with terms-of-trade movements working through wage adjustments across locations. The fear that TTIP might only benefit already rich German counties at the cost of poorer ones is thus not backed. Yet even in our ambitious scenario the potential gains are limited to between $0.31 \%$ and $0.71 \%$ of real income. With labor mobility within Germany, these welfare effects level out at $0.46 \%$.

Fifth, a long-run scenario of perfect population mobility within the European Union predicts migration flows from eastern European countries into Ireland, Luxemburg and, to a lesser extent, into Belgium, the Netherlands, Great Britain, and Malta. As a result of extreme trade liberalization, real income gains among EU members would be at a joint level of $0.32 \%$. Our analysis shows that the bulk of the adjustment to such a spatial equilibrium within the EU would take place through the adjustment of land prices. 
Finally, contrasting transatlantic trade liberalization with a multilateral trade deal we find that a multilateral reduction of trade barriers in the range of $0.5 \%$ to $1 \%$ would be enough for the EU to achieve the same welfare gains as in our most ambitious TTIP scenario. For the US, however, this would require a decrease in multilateral barriers of $2.5 \%$ to $3 . \%$. This finding points to the importance of Bhagwati's (1994) prediction that a 'hegemonic power' is likely to gain more by bargaining sequentially than simultaneously and hence, provides one explanation why the US favors preferential liberalization today.

Relation to the previous literature. Our analysis is related to the growing literature on new quantitative trade modelling. This literature has provided momentous stimuli to the research pertaining to the quantification of the gains from trade and the consequences of the globalization of economic activity, more generally. These new models have solid, yet possibly different, micro-foundations (spanning from perfect competition to monopolistic competition), which give rise to common gravity-type macro-level predictions for bilateral trade flows as a function of bilateral trade costs. We build on the Ricardian tradition established by the seminal work of Eaton and Kortum (2002) and generalized by Redding (2016) to comprehend factor mobility and by Caliendo and Parro (2015) to comprise an arbitrary number of heterogeneous interlinked industries. These new quantitative trade models have been applied to trade policy and trade liberalization issues, recently. Important examples are Ossa (2014), addressing optimal tariffs in a world-wide trade war, Redding (2014), studying the trade integration between the United States and Canada, Costinot and Rodriguez-Claré (2014), providing estimates of trade integration for OECD countries, and Caliendo and Parro (2015), examining the trade integration between the United States and Mexico in the wake of the establishment of NAFTA. Our model bears close resemblance with the model developed in Caliendo et al. (2014) who, in studying labor elasticities across US states, also allow for labor mobility. They abstract from all international economic interactions, however. ${ }^{10}$ Moreover, in conspicuous contrast to both Caliendo et al. (2014) and Caliendo and Parro (2015), we take into account that land is not only used in production but also in consumption, a difference that has strong significance for the quantitative results. ${ }^{11} \mathrm{We}$ are the first to explore trade liberalization under a TTIP in a model which jointly considers input-output linkages, land for consumption and production and labor mobility.

\footnotetext{
${ }^{10}$ A minor difference is that in our model, contrary to Caliendo et al. (2014), the continuum of varieties produced in each sector enters consumer's utility rather than final goods production. Specifically, we extend the two sector framework (manufacturing and agriculture) of Michaels et al. (2012) to an arbitrary number of sectors.

${ }^{11}$ Pflüger and Tabuchi (2011) highlight the role of land for consumption and production from a new economic geography perspective building on Helpman (1998), see also Fujita and Thisse (2013).
} 
Our paper also relates to the small literature which has provided estimates of the economic effects of a transatlantic trade and investment partnership. Francois et al. (2013) set up a multiregion, multi-sector global computable general equilibrium (CGE) model which, in most sectors, assumes perfect competition under the Armington assumption, but in some heavy manufacturing sectors allows for imperfect and monopolistic competition and thereby also accounts for gains from specialization. In addition to looking at static effects, longer-run impacts of trade through investment effects on capital stocks are also considered. The data on non-tariff barriers are drawn from Ecorys (2009). Fontagné et al. (2013) base their computations on MIRAGE, another computable general equilibrium for the world economy developed by CEPII. This model differs in some choices from Francois et al. (2013) but also features multiple industries and it also relies on the Armington assumption. Egger et al. (2015) complement the use of similar computational methods with econometric techniques to establish a potential TTIP shock. Our analysis differs from works of this type both in our modelling approach, the reliance on a medium-sized new quantitative trade model with Ricardian micro-foundations rather than the Armington approach, and our different solution method, which is less demanding in terms of the parameters needed. Given our far different choices, we consider our analysis to be complementary to these studies.

The work by Felbermayr et al. $(2015 ; 2013)$ and Aichele et al. $(2016)$ is closest to our approach. Felbermayr et al. $(2015 ; 2013)$ use a structurally estimated single-sector general equilibrium model in the tradition of Helpman and Krugman (2005). The strategy pursued in Felbermayr et al. $(2015 ; 2013)$ differs from the computable general equilibrium tradition in that the parameters of the model are estimated on those data that the model has to replicate in the baseline equilibrium without drawing on the method established by Dekle et al. (2007). Aichele et al. (2016), in contrast, draw on this methodology and follow this line of research by using a model in the Ricardian tradition of Eaton and Kortum (2002) and Caliendo and Parro (2015), thereby also taking account of input-output linkages. Our analysis differs from theirs, most notably in our inclusion of land in consumption and production and in our spatial equilibrium perspective. Moreover, we allow for a corridor of liberalization scenarios, whereas a key focus of Aichele et al (2016) is to base their analysis of TTIP on an estimate of shallow and deep integration scenarios observed in previous preferential trade agreements. We address their preferred scenario in our robustness analysis.

The structure of our paper is as follows. Chapter 2 sets up our quantitative general equilibrium model. Chapter 3 characterizes our empirical methodology and the data. Chapter 4 proceeds to 
our empirical analyses starting out with the pure trade effects and concluding with a discussion against the background of other analyses. Chapter 5 offers some final remarks.

\section{The model}

The setup. Our analysis builds on the quantitative trade modelling that evolved in the wake of Eaton and Kortum (2002). We consider a version of the model developed in Redding (2014; 2016) with two production factors, labor and land. Final goods and intermediate goods are traded at a cost between all locations and labor is mobile between subgroups of all locations. We extend Redding's one-sector framework to comprise an arbitrary number of heterogeneous industries (sectors) similar to Caliendo and Parro (2015).

The economy consists of $N$ locations, indexed by $n, i$ or $s$. Each location is endowed with an exogenous quality-adjusted amount of land and structures $H_{n}$. The amount of labor $L_{n}$ available at location $n$ is either exogenously given or emerges endogenously in a subset of locations among which labor is mobile. Land and labor are used to produce a continuum of differentiated goods in each of $K$ industries (sectors) indexed by $k$ or $j$. All locations can trade with each other subject to iceberg trade costs so that $d_{\text {nik }} \geq 1$ units of a good produced in industry $k$ in location $i$ have to be shipped in order for one unit to arrive at location $n$. We assume that goods trade within a location is costless, $d_{n n k}=1$. Workers are perfectly mobile between sectors at any location.

This framework flexibly allows for internal and external geographies at different levels. Subsets of locations, $N^{m} \subset N$, will be called countries and/or country groups and indexed by $m$. Such spatial entities are exogenously endowed with a measure of $\bar{L}^{m}$ workers who supply 1 unit of labor each and workers are assumed to be mobile (in the long-run) within such spatial entities but not across them. In a long-run spatial equilibrium, real wages are equalized across locations of a spatial entity and $\bar{L}^{m}=\sum_{n \in m} L_{n}$.

Preferences. Preferences of the representative consumer in location $n$ are defined over the consumption of goods $C_{n}$ and the residential use of land $H_{n}^{C}$ and take the Cobb-Douglas form:

$$
U_{n}=\left(\frac{C_{n}}{\alpha}\right)^{\alpha}\left(\frac{H_{n}^{C}}{1-\alpha}\right)^{1-\alpha}, \quad 0<\alpha<1
$$

The consumption aggregate $C_{n}$ is defined over the consumption of the outputs of $k=1 \ldots K$ industries $\left(C_{n k}\right)$ and is also assumed to be of Cobb-Douglas form

$$
C_{n}=\prod_{k=1}^{K} C_{n k} \delta_{n C}^{k}, \quad 0 \leq \delta_{n C}^{k} \leq 1, \sum_{k=1}^{K} \delta_{n C}^{k}=1
$$


where $\delta_{n C}^{k}$ are the constant consumption shares on industries $k$. Each industry offers a continuum of varieties $\omega \in[0,1]$ which enter preferences according to a constant elasticity of substitution function

$$
C_{n k}=\left[\int_{0}^{1} q_{n k}(\omega)^{\frac{\sigma_{k}-1}{\sigma_{k}}} d \omega\right]^{\frac{\sigma_{k}}{\sigma_{k}-1}} \quad \sigma_{k}>1
$$

where $q_{n k}(\omega)$ is location $n$ 's consumption of variety $\omega$ produced in industry $k$ and $\sigma_{k}$ denotes the (constant) within-industry elasticity of substitution between any two varieties. The assumption of a continuum of varieties within each sector ensures that each individual good and producer are of zero weight within the economy.

Production. Production of each variety $\omega$ within any industry $k$ and at any location $n$ takes place with constant returns to scale and under perfect competition combining labor, land and all available varieties of outputs as intermediate inputs. Locations and industries differ in terms of their input mix and their productivities $z_{n k}(\omega)$, however. We follow Eaton and Kortum (2002) by assuming that productivities are drawn independently from location and industry specific Fréchet distributions with cumulative density functions given by

$$
F_{n k}\left(z_{n k}\right)=e^{-T_{n k} z_{n k}{ }^{-\theta} k}
$$

where $T_{n k}$ is a scale parameter which determines average productivity and the shape parameter $\theta_{k}$ controls the dispersion of productivities across goods within each sector $k$, with a bigger $\theta_{k}$ implying less variability. Taking iceberg costs $d_{n i k} \geq 1$ into account, the cost to a consumer in location $n$ of buying one unit of $\omega$ in sector $k$ from a producer in location $i$ is thus

$$
p_{n i k}(\omega)=\frac{d_{n i k} c_{i k}}{z_{i k}(\omega)}
$$

where $c_{i k}$ are the costs of an input bundle given by

$$
c_{i k}=w_{i}^{\beta_{i k}} r_{i}^{\eta_{i k}} \rho_{i k}^{1-\beta_{i k}-\eta_{i k}}, \quad 0<\beta_{i k}<1,0<\eta_{i k}<1
$$

with $w_{i}, r_{i}$ and $\rho_{i k}$ being the wage rate, the rental rate of land, and the industry specific index of intermediate input prices in $i$, respectively, and where $\beta_{i k}$ and $\eta_{i k}$ are the exogenous cost shares of labor and land.

Expenditure shares and price indices. Consumers and producers treat goods as homogeneous and consequentially source each good from the location that provides it at the lowest price. Hence,

$$
p_{n k}(\omega)=\min \left\{p_{n i k}(\omega) ; i=1 \ldots N\right\} \quad k=1 \ldots K
$$


Using equilibrium prices and the properties of the Fréchet distribution as in Eaton and Kortum (2002), the share of expenditure of location $n$ in industry $k$ on varieties produced in $i$ is

$$
\pi_{n i k}=\frac{T_{i k}\left(d_{n i k} c_{i k}\right)^{-\theta_{k}}}{\sum_{s=1}^{N} T_{s k}\left(d_{n s k} c_{s k}\right)^{-\theta_{k}}}
$$

where, by construction, $\sum_{i} \pi_{n i k}=1$. The implied perfect CES price index $P_{n k}$ for industry aggregates (subutility) $C_{n k}$ is

$$
P_{n k}=\gamma_{k}\left[\sum_{i=1}^{N} T_{i k}\left(d_{n i k} c_{i k}\right)^{-\theta_{k}}\right]^{-\frac{1}{\theta_{k}}}
$$

where $\gamma_{k} \equiv\left[\Gamma\left(\frac{\theta_{k}+1-\sigma_{k}}{\theta_{k}}\right)\right]^{\frac{1}{1-\sigma_{k}}}$ and $\Gamma(\cdot)$ denotes the gamma function and where we assume that $1+\theta_{k}>\sigma_{k}$. The Cobb-Douglas price index for overall consumption is:

$$
P_{n}=\prod_{k=1}^{K} P_{n k}^{\delta_{n C}^{k}}
$$

Finally, we allow for the intermediate goods mix used by firms to differ from the mix used in consumption and to vary across industries and regions. Hence, the intermediate goods price index $\rho_{n j}$ of industry $j$ in location $n$ can be written as

$$
\rho_{n j}=\prod_{k=1}^{K} P_{n k}^{\delta_{n j}^{k}}, \quad 0 \leq \delta_{n j}^{k} \leq 1, \quad \sum_{k=1}^{K} \delta_{n j}^{k}=1
$$

where $\delta_{n j}^{k}$ is the share of industry $k$ in the input mix of industry $j$ in location $n$.

Income and land rents. We follow Redding (2016) by assuming that a location's land rent is evenly distributed among that location's consumers. Hence, with $v_{n}$ denoting expenditure per capita in $n$, that location's total expenditure is

$$
v_{n} L_{n}=w_{n} L_{n}+(1-\alpha) v_{n} L_{n}+\sum_{k=1}^{K} \eta_{n k} R_{n k}+D_{n}
$$

where $R_{n k}$ is the total revenue of industry $k$ firms in location $n$ and $D_{n}$ a fixed transfer accounting for the location's trade deficit (surplus if negative). ${ }^{12}$ The first term on the right hand side (RHS) is labor income from production and the two following terms are the incomes from expenditures on residential land use and from commercial land use, respectively. Since labor costs are a constant share $\beta_{n k}$ of revenue in each industry,

$$
w_{n} L_{n}=\sum_{k=1}^{K} \beta_{n k} R_{n k},
$$

we can rewrite total expenditure as:

\footnotetext{
${ }^{12}$ Notice that while we keep the overall bilateral trade deficits exogenously fixed, the sectoral bilateral trade deficits are endogenously determined in the model.
} 


$$
v_{n} L_{n}=\frac{\sum_{k=1}^{K}\left(\beta_{n k}+\eta_{n k}\right) R_{n k}+D_{n}}{\alpha}
$$

Goods market clearing commands that the sum of spending from all locations on goods produced in location $i$ and industry $k$ must equal that industry's revenue. Using eq. (14) this yields:

$$
R_{i k}=\sum_{n=1}^{N} \pi_{n i k}\left\{\sum_{j=1}^{K}\left[\delta_{n C}^{k}\left(\beta_{n j}+\eta_{n j}\right)+\delta_{n j}^{k}\left(1-\beta_{n j}-\eta_{n j}\right)\right] R_{n j}+\delta_{n C}^{k} D_{n}\right\}
$$

where the term in parenthesis represents the combined consumption and intermediate demand of location $n$ for industry $k$ goods.

Land market clearing requires that for any location $n$ total rent income must equal total spending on land:

$$
r_{n} H_{n}=(1-\alpha) v_{n} L_{n}+\sum_{k=1}^{K} \eta_{n k} R_{n k}
$$

This together with eq. (14) allows to write a location's rental rate of land in terms of its endogenously determined revenues, as well as its exogenously given trade deficit and supply of land:

$$
r_{n}=\frac{\sum_{k=1}^{K}\left[(1-\alpha) \beta_{n k}+\eta_{n k}\right] R_{n k}+(1-\alpha) D_{n}}{\alpha H_{n}}
$$

Labor mobility. Corresponding to utility function (1), the welfare of a worker residing in location $n$, is given by her real income

$$
V_{n}=\frac{v_{n}}{P_{n}{ }^{\alpha} r_{n}{ }^{1-\alpha}}
$$

The mobility of labor across locations within a spatial entity $m$ ensures that real incomes are equalized (whilst the immobility of workers across spatial entities implies that real incomes can differ across countries). Hence, there is a common utility level $\bar{V}^{m}$ which pertains across locations within spatial entity $m$. Using income per capita from eq. (14) and the rental rate of land from eq. (16) we can solve for the population in location $n$ in terms of the endogenously determined revenues, price indices, and common utility level, as well as the exogenously given trade deficit and housing supply:

$$
L_{n}=\frac{\sum_{k=1}^{K}\left(\beta_{n k}+\eta_{n k}\right) R_{n k}+D_{n}}{\alpha^{\alpha} P_{n}{ }^{\alpha}\left[\frac{\sum_{k=1}^{K}\left((1-\alpha) \beta_{n k}+\eta_{n k}\right) R_{n k}+(1-\alpha) D_{n}}{H_{n}}\right]^{1-\alpha} \bar{V}^{m}}, \quad \forall n \in N^{m}
$$

General equilibrium. The general equilibrium of the model can be represented by the following system of four equations which jointly determines for all locations $\boldsymbol{n}$ the set of 
industry revenues $R_{n k}$, price indices $P_{n k}$, each location's sectoral trade shares $\pi_{n i k}$ and the population shares in each location, $\lambda_{n}^{m} \equiv L_{n} / \bar{L}^{m}$ :

$$
\begin{gathered}
\pi_{n i k}=\frac{T_{i k}\left(d_{n i k} c_{i k}\right)^{-\theta_{k}}}{\sum_{s=1}^{N} T_{s k}\left(d_{n s k} c_{s k}\right)^{-\theta_{k}}} \\
\left.R_{i k}=\sum_{n=1}^{N} \pi_{n i k}\left\{\sum_{j=1}^{K}\left[\delta_{n C}^{k}\left(\beta_{n j}+\eta_{n j}\right)+\delta_{n j}^{k}\left(1-\beta_{n j}^{N}-\eta_{n j}\right)\right] R_{n j}+\delta_{n C}{ }_{n i k} c_{i k}\right)^{-\theta_{k}}\right]^{-\frac{1}{\theta_{k}}} \\
\lambda_{n}^{m}=\frac{\frac{\sum_{k=1}^{K}\left(\beta_{n k}+\eta_{n k}\right) R_{n k}+D_{n}}{P_{n} \alpha\left(\frac{\sum_{k=1}^{K}\left((1-\alpha) \beta_{n k}+\eta_{n k}\right) R_{n k}+(1-\alpha) D_{n}}{H_{n}}\right)^{1-\alpha}}}{\sum_{i \in N} m\left[\frac{\sum_{k=1}^{K}\left(\beta_{i k}+\eta_{i k}\right) R_{i k}+D_{i}}{P_{i}^{\alpha}\left(\frac{\sum_{k=1}^{K}\left((1-\alpha) \beta_{i k}+\eta_{i k}\right) R_{i k}+(1-\alpha) D_{i}}{H_{i}}\right)^{1-\alpha}}\right]}
\end{gathered}
$$

where $c_{i k}=\left(\frac{\sum_{k=1}^{K} \beta_{i k} R_{i k}}{L_{i}}\right)^{\beta_{i k}}\left(\frac{\sum_{k=1}^{K}\left((1-\alpha) \beta_{i k}+\eta_{i k}\right) R_{i k}+(1-\alpha) D_{i}}{\alpha H_{i}}\right)^{\eta_{i k}}\left(\prod_{j=1}^{K} P_{i j}^{\delta_{i k}^{j}}\right)^{1-\beta_{i k}-\eta_{i k}}$

This equation system involves the bilateral industry trade shares, eq. (8), price indices, eq. (9), and goods market clearing, eq. (15). The shares of spatial entity $m$ 's population living in location $n$, eq. (19), follow from applying $\lambda_{n}^{m} \equiv L_{n} / \bar{L}^{m}$ together with $\bar{L}^{m}=\sum_{n \in N^{m}} L_{n}$ to eq. (18). Finally, the marginal $\operatorname{costs} c_{i k}$ are calculated by using the input price indices, eq. (11), wages, eq. (13), and rental rates of land, eq. (16), to replace the corresponding values in eq. (6).

\section{Empirical Strategy}

\subsection{Counterfactual analysis}

We apply the method introduced by Dekle, Eaton and Kortum (2007) to study the effects of a counterfactual change in trade costs, $d_{\text {nik }}$. We denote the value that an endogenous variable $x$ takes in the counterfactual equilibrium with a prime $\left(x^{\prime}\right)$ and its relative value in the counterfactual and initial equilibria by a hat $\left(\hat{x} \equiv x^{\prime} / x\right)$. Starting from the equilibrium system specified in the previous section and defining total expenditure $Y_{n} \equiv v_{n} L_{n}$, and total wage income $W_{n}=w_{n} L_{n}$ the counterfactual equilibrium values must satisfy:

$$
\begin{aligned}
& \pi_{n i k}^{\prime}=\frac{\pi_{n i k}\left(\hat{d}_{n i k} \hat{c}_{i k}\right)^{-\theta_{k}}}{\sum_{s \in N} \pi_{n s k}\left(\hat{d}_{n s k} \hat{c}_{s k}\right)^{-\theta_{k}}} \\
& \hat{P}_{n k}=\left[\sum_{i=1}^{N} \pi_{n i k}\left(\hat{d}_{n i k} \hat{c}_{i k}\right)^{-\theta_{k}}\right]^{-\frac{1}{\theta_{k}}}
\end{aligned}
$$




$$
\begin{gathered}
R_{i k}^{\prime}=\sum_{n=1}^{N} \pi_{n i k}^{\prime}\left\{\sum_{j=1}^{K}\left[\delta_{n C}^{k}\left(\beta_{n j}+\eta_{n j}\right)+\delta_{n j}^{k}\left(1-\beta_{n j}-\eta_{n j}\right)\right] R_{n j}^{\prime}+\delta_{n C}^{k} D_{n}\right\} \\
\lambda_{n}^{\prime m}=\frac{\lambda_{n}^{m}\left(\frac{\widehat{Y}_{n}}{\widehat{P}_{n}^{\alpha} \widehat{r}_{n}{ }^{1-\alpha}}\right)}{\sum_{i \in N} \lambda_{i}^{m}\left(\frac{\widehat{Y}_{i}}{\widehat{P}_{i}^{\alpha} \widehat{r}_{i}{ }^{1-\alpha}}\right)}
\end{gathered}
$$

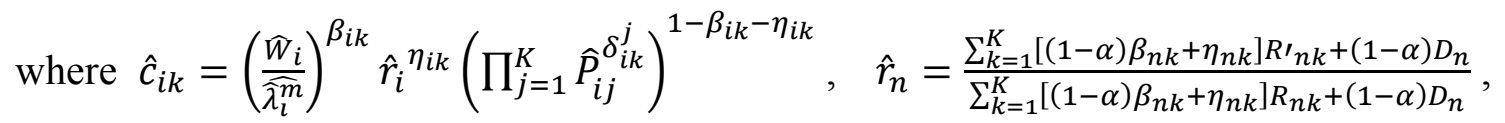

$$
\widehat{W}_{n}=\frac{\sum_{k=1}^{K} \beta_{i k} R^{\prime} i k}{\sum_{k=1}^{K} \beta_{i k} R_{i k}} \quad \text { and } \quad \hat{Y}_{n}=\frac{\sum_{k=1}^{K}\left(\beta_{n k}+\eta_{n k}\right) R^{\prime} n k+D_{n}}{\sum_{k=1}^{K}\left(\beta_{n k}+\eta_{n k}\right) R_{n k}+D_{n}}
$$

The implied change in real income $\left(\hat{V}_{n} \equiv V_{n}^{\prime} / V_{n}\right)$ for a consumer living in location $n$ is then, under labor mobility:

$$
\hat{V}_{n}=\frac{\hat{\varphi}_{n}}{\hat{r}_{n}^{1-\alpha}} \prod_{k} \hat{A}_{n n k}^{-\alpha \frac{\delta_{n C}^{k}}{\theta_{k}}} \hat{c}_{n k}^{-\alpha \delta_{n C}^{k}}
$$

An inspection of the equation system characterizing the counterfactual, eq. (21) - (24) and of the implied change in the real income (25) reveals the parsimony of our method. In order to numerically solve this equation system we only need information concerning a small number of exogenous variables, the share of goods in consumption $(\alpha)$, the cost shares of labor and land (or intermediates), $\left(\beta_{n k}, \eta_{n k}\right.$ or $\left.1-\beta_{n k}-\eta_{n k}\right)$, sectoral expenditure and cost shares $\left(\delta_{n C}^{k}, \delta_{n j}^{k}\right)$ for which data are readily available, and estimates for the sectoral productivity dispersion $\left(\theta_{k}\right)$. Neither does our method require information concerning the elasticity of substitution $\left(\sigma_{k}\right)$, nor on the location- and sector specific scale parameters of technology $\left(T_{n k}\right)$ or the factor supplies (except for population shares of locations within spatial entities). Most importantly, however, no information is needed concerning the multidimensional matrix of trade frictions $\left(d_{n i k}\right)$, the key advantage of this method established by Dekle, Eaton and Kortum (2007).

Notice that a regime of pure trade but without factor mobility among a subset of locations is simply represented by imposing $\hat{\lambda}_{n}^{m}=\lambda_{n}^{\prime m} / \lambda_{n}^{m}=1$ in the above system. We will make use of this in our ensuing empirical analysis in order to identify and distinguish the (medium-run) pure trade effects from the longer-run effects of labor mobility within the European Union, in one scenario, and among the counties of Germany, in another scenario.

\subsection{Data}

In addition to the data requirements concerning the exogenous parameters of our model $\left(\alpha, \beta_{n k}\right.$, $\left.\eta_{n k}, \delta_{n C}^{k}, \delta_{n j}^{k}, \theta_{k}\right)$ we need a matrix of bilateral industry trade shares $\pi_{n i k}$ which includes owntrade. We use the World Input Output database (WIOD) as our main data source. This data set 
provides a time-series of world input-output tables compiled on the basis of officially published input-output tables in combination with national accounts and international trade statistics. We take the data for the year 2014 as it is the most current year available in the database at the time of writing. The world input-output table for this year covers data from 56 industries in 44 countries, including one artificial "rest of the world" (ROW) country.

Due to differences in sector classifications across countries, some countries have zero output and consumption in some of these sectors. To avoid the problems associated with zero output and consumption we aggregate the data to 35 industries according to table A1 in the appendix and we drop real estate services for reasons spelt out below. The countries include all current members of the European Union, as well as the US and all major trading partners of the EU and the US. The complete list is provided in table A2 in the appendix. We use the resulting inputoutput table to derive the consumption and intermediate good shares $\left(\delta_{n C}^{k}\right.$ and $\left.\delta_{n j}^{k}\right)$, the share of value added $\left(\beta_{n k}+\eta_{n k}\right)$ and the bilateral industry trade shares $\left(\pi_{n i k}\right)$. Appendix A1 explains this derivation and details how we handle inventory changes and zeros in bilateral trade flows. To implement Redding's (2014; 2016) new quantitative spatial model we also need parameter values for the consumption share of land $(1-\alpha)$ and the cost shares of land in all industries $\left(\eta_{i k}\right)$. One might suspect that the WIOD along with complementary databases is the best choice for that purpose. After all, the World-Input-Output-Table (WIOT) features a sector 'real estate services' whose output is an intermediate for the other sectors and also enters final demand. Moreover, the WIOT also provides information on the value added of all industries at the national level, which the Socio-Economic Accounts (SEAs) of the WIOD then split into the compensation of labor and capital, with the latter being further decomposed in the EU-KLEMSdatabase into a list of asset categories which includes residential and non-residential structures and which is also meant to include a separate category 'land' (see Erumban et al. 2012 on the SOE's; and van Ark 2005 on EU-KLEMS). Serious data problems make such an approach impossible, however. ${ }^{13}$ To start, the total share of capital in value added is calculated only residually in input-output tables and national accounts. More severe, even though the EUKLEMS is intended to include 'land' and even though there are suggested ways to arrive at estimates of its use, data on land are lacking, as yet (van Ark 2005; O’Mahoney and Timmer 2009). This implies that the share $(1-\alpha)$ would have to be conjectured from the categories residential and non-residential structures alone. The problem with these asset categories is that

\footnotetext{
${ }^{13}$ We are very grateful for conversations with Gaaitzen de Vries and with Martin Gornig who shared their expertise with us on these issues.
} 
there are also serious deficiencies in how they are recorded. To take one example, whereas the category 'residential structures' contains imputations for the use of self-owned housing, no similar imputation is made for 'non-residential structures'. This leads to a crass underestimation of the use of 'non-residential structures'. For example, non-residential structures contribute nearly nothing to the value-added in the sector 'real estate activities' in many countries in the EU-KLEMS. ${ }^{14}$ An inspection of the EU-KLEMS data also reveals national idiosyncracies in recording these data. ${ }^{15}$

Since these data problems are severe and abounding we base our parameter estimates for the consumption share of land and the cost shares of land in intermediates on other sources. In order not to overestimate the impact of land but still to be able to use the WIOT as our backbone for all other calculations, we eliminate the real estate sector from the WIOT. We explain in App A1 in the Appendix how we arrive at an internally consistent refined world input-output table. Our parameter for the consumption share of land is based on the entry for housing in the usetables of the United States' Bureau of Economic Analysis and census data for housing from the German Statistical Office Destatis. Relating those to the respective values for total final expenditure, including government spending and investments, and averaging we arrive at a value of $(1-\alpha)=0.08642$. To split value added between labor and land and structures, we borrow from Valentinyi and Herrendorf (2008), who calculate the income shares of land and structures for different US sectors. In particular we set the share of land in value added at $32 \%$, $15 \%, 9 \%$, and $21 \%$ in agricultural, manufacturing, construction and service sectors, respectively.

For data on the labor force we rely on the International Labor Associations' estimates of the labor force from ILOSTAT for 2014.

We estimate the technological dispersion parameters $\theta_{k}$ based on the 'gravity' relationship implied by our model as we explain in the next section. Using these estimates we calculate the Head-Ries Index (Head and Mayer 2014) as detailed in appendix A2. This is important because it gives us an estimate of the upper threshold for the feasible tariff-liberalization corridor. ${ }^{16}$

\footnotetext{
${ }^{14}$ A further issue is that the intermediate input of 'real estate' activities for other industries has high entries in the WIOT despite consisting mainly of 'residential structures'.

${ }^{15}$ For instances, in Germany the asset category 'residential structures' is used in the real estate services sector only, whilst in Spain, the Netherlands and Finland, to take three examples, 'residential structures' enter the value-added of further sectors.

${ }^{16}$ Moving beyond this threshold implies negative trade barriers, i.e. subsidies.
} 


\subsection{Estimating technological dispersion}

In order to obtain estimates of the technological dispersion parameters $\theta_{k}$ we draw on the gravity equation implied by our model. Using eq. (8) and the definition of the bilateral trade share $\pi_{\text {nik }}=X_{\text {nik }} / E_{n k}$, where $X_{\text {nik }}$ is the value of the trade flow for industry $k$ between exporting country $i$ and destination country $n$, and where $E_{n k}=\delta_{n C}^{k} \alpha v_{n} L_{n}+\sum_{j=1}^{K} \delta_{n j}^{k}(1-$ $\left.\beta_{n j}-\eta_{n j}\right) R_{n j}$ is country $n$ 's total spending in industry $k$, we obtain, after rearranging,

$$
X_{n i k}=M_{n k} S_{i k} d_{n i k}^{-\theta_{k}}
$$

where $M_{n k} \equiv \frac{E_{n k}}{\sum_{s=1}^{N} T_{s k}\left(d_{n s k} c_{s k}\right)^{-\theta}}$ and $S_{i k} \equiv T_{i k} c_{i k}{ }^{-\theta_{k}}$ are country-industry specific effects of the importer and the exporter, respectively. $M_{n k}$ comprises all those features of the market for $k$ in the destination location $n$ that promote shipments from all other locations and $S_{i k}$ comprises features of the supplier location $i$ that are relevant for all destination regions. The transportation cost term $d_{n i k}{ }^{-\theta}$ is the only factor that is specific to the bilateral relation between exporter $i$ and the importer $n$.

The standard gravity literature estimates equation (26) or a version thereof in log-linear form with importer and exporter fixed effects and by proxying log barriers with a sum of log distance, $\log$ tariffs and a range of binary indicator variables for contiguity, common language, common colonial past and so on. However, recent research has shown that this leads to biased results since the multilateral resistance terms in $M_{n k}$ and $S_{i k}$ are then based on estimated instead of true bilateral trade costs (Egger and Nigai 2015). A second issue is the potential endogeneity of trade policy (Baier and Bergstrand 2007). Further problems for this standard approach are zero trade flows (which have to be dropped) and potential heteroscedasticity. As a solution to these problems recent literature suggests to rely on panel data, include a time-invariant asymmetric bilateral fixed effect $\left(D_{\text {nik }}\right)$ and employ a Poisson pseudo-maximum likelihood (PPML) estimation on the following transformed regression equation

$$
X_{n i k t}=M_{n k t} S_{i k t} e^{\left(D_{n i k}+R T A_{n i t}-\theta_{k} \log \left(1+\tau_{n i k t}\right)\right)}
$$

where $\tau_{\text {nikt }}$ denotes tariffs and where $R T A_{\text {nit }}$ is a dummy that is equal to 1 if countries $n$ and $i$ are members of a common regional trade agreement at time $t$ (Egger and Nigai 2015; Piermartini and Yotov 2016; Santos Silva and Tenreyro 2006, 2012; Yotov et al. 2016).

We obtain tariff data from the WITS/UNCTAD TRAINS database. Unfortunately, tariff data is not available aggregated to the ISIC Rev. 4 / CPA 2008 level used in the WIOD's 2016 release. Therefore, we rely on data reported according to the HS 2007 or HS 2012 classification, for 
which a precise (many-to-one) matching to the 2-digit CPA 2008 classification is possible with concordance tables from Eurostat. ${ }^{17}$ To ensure consistency between the matching and aggregation process of our trade and tariff data we rely on Comtrade data from WITS, given in the same original HS classification as tariffs and we extend our country sample to all countries for which tariff and trade data is available. ${ }^{18}$ In accordance with the mentioned literature we use only every third year, allowing for the adjustment of fixed effects over time. Data for RTA's are from Mario Larch's Regional Trade Agreements Database. ${ }^{19}$

Table 1: Estimates of the technological dispersion parameter

\begin{tabular}{|c|c|c|c|c|}
\hline Industry & $\theta_{k}$ & z-ratio & $\mathrm{N}$ & Pseudo $\mathrm{R}^{2}$ \\
\hline Crop and Animal Production & $1.121 * *$ & 2.088 & 22907 & 0.9947 \\
\hline Forestry & $4.204 * *$ & 2.090 & 8642 & 0.9973 \\
\hline Fishing & $3.824 *$ & 1.703 & 8715 & 0.9926 \\
\hline Mininig & $22.683 * * *$ & 2.956 & 14628 & 0.9906 \\
\hline Food, Beverages, Tobacco & $1.128 * * *$ & 3.148 & 27721 & 0.9914 \\
\hline Textiles, Leather & $1.023^{\mathrm{a}}$ & 1.587 & 29976 & 0.9959 \\
\hline Wood & $2.648 * * *$ & 3.970 & 18641 & 0.9977 \\
\hline Paper, Printing & $2.955 * * *$ & 5.123 & 20544 & 0.9979 \\
\hline Chemicals, Pharmaceutical & $2.151 * *$ & 2.120 & 29244 & 0.9924 \\
\hline Plastics & $1.410^{* * *}$ & 3.669 & 26631 & 0.9983 \\
\hline Non-Metallic Minerals & $3.651 * * *$ & 6.410 & 22096 & 0.9945 \\
\hline Basic Metals & $4.150 * * *$ & 3.068 & 20233 & 0.9805 \\
\hline Fabricated Metals & $2.269 * * *$ & 3.584 & 26966 & 0.9970 \\
\hline Computer & $3.273 * *$ & 2.058 & 30452 & 0.9974 \\
\hline Electrical & $2.770 * * *$ & 4.827 & 28250 & 0.9986 \\
\hline Machinery n.e.c & $3.309 * * *$ & 3.917 & 29691 & 0.9982 \\
\hline Transport Equipment & $1.011 * *$ & 2.527 & 25764 & 0.9980 \\
\hline Other Manufacturing & $2.597 * * *$ & 3.795 & 27356 & 0.9985 \\
\hline Utilities & $14.30 * * *$ & 6.235 & 13095 & 0.9904 \\
\hline
\end{tabular}

${ }^{\mathrm{a}} \mathrm{p}<0.15 ;{ }^{*} \mathrm{p}<0.1 ; * * \mathrm{p}<0.05 ;{ }^{* * *} \mathrm{p}<0.01$; Pseudo $\mathrm{R}^{2}$ is the square of correlation between fitted values and data. High correlation is due to the use of bilateral fixed effects.

Table 1 sums up key results (Appendix table A3 provides the full results). The $\theta_{k}$ 's are in the range of expected values and significant across industries with the exception of the textiles industry which is only significant at the $15 \%$ level. As expected, industries which are likely to produce more homogeneous goods such as mining, utilities (including gas, electricity and water) and basic metals tend to have higher $\theta_{k}$ 's implying stronger reactions of flows to changes in trade costs. On the other hand more differentiated sectors such as food, beverages and tobacco, transport equipment or crop and animal production exhibit lower values.

\footnotetext{
17 There are 32 6-digit HS codes for which the corresponding 2 digit CPA sector is ambiguous. We assign these codes to one of the potential sectors based on their description.

${ }^{18}$ In aggregating tariff data from the product to the industry level we rely on import weighted averages and use total imports as weights in case of zero bilateral industry flows.

${ }^{19}$ The database can be acceded at http://www.ewf.uni-bayreuth.de/en/research/RTA-data/index.html.
} 


\subsection{Quantifying the TTIP shock}

While the parsimony of our model and method allow us to avoid the quantification of the current level of NTBs, we still need to be concerned with the relative change of NTBs implied by the introduction of TTIP. Even after many rounds of negotiations between the EU and the US it is impossible to know how 'deep' a final trade agreement might eventually be and how the various sectors could be affected. However, even if we knew the final outcome (e.g. the harmonization of standards in the car industry or agreements on the testing of pharmaceutical or medical products), there is no simple way to translate these (reductions of) barriers into tariff equivalents. Previous research has dealt with this issue in two different ways. One line has followed a 'bottom-up' approach and has indeed tried to figure out tariff equivalents of the prevailing NTBs. Given the derived tariff equivalents these studies then proceeded to specific reduction scenarios based on experts' and practitioners' assumptions about the potential of TTIP and the share of negotiable versus non-negotiable barriers (e.g. different languages or geographical distance). This methodology has led to widely differing results, however. The table below lists the tariff equivalents that two of the most influential studies have obtained, Ecorys (2009) on which the study of Francois et al. (2013) for the EU commission is based, and Fontagné et al. (2013). The numbers are confined to the three broad sectors agriculture, manufacturing and services. In view of these problems and discrepancies, Felbermayr et al. (2013) go so far to argue that no consistent and reliable quantification is possible for NTBs on the sectoral level.

Table 2: Estimated tariff equivalents

\begin{tabular}{llllll}
\hline & Ecorys (2009) & & & Fontagné et al. (2013) \\
\cline { 2 - 3 } \cline { 5 - 6 } \cline { 5 - 6 } & $\mathrm{US} \rightarrow \mathrm{EU}$ & $\mathrm{EU} \rightarrow \mathrm{US}$ & & $\mathrm{US} \rightarrow$ EU & $\mathrm{EU} \rightarrow$ US \\
\hline agriculture & 56.8 & 73.3 & & 48.2 & 51.3 \\
manufacturing & 19.3 & 23.4 & & 42.8 & 32.3 \\
services & 8.5 & 8.9 & & 32.0 & 47.3 \\
\hline
\end{tabular}

Egger et al. (2015), Felbermayr et al. (2013; 2015) and Aichele et al. (2016) use an alternative 'top down approach' whereby estimates of the effects of existing trade agreements on bilateral trade volumes in different industries are used to calibrate the TTIP shock to result in these volume changes. Compared to the often considered symmetric barrier cuts in the 'bottom-up' approaches this has the advantage that it allows for shocks to vary across industries which opens 
a further channel for welfare effects. On the other hand, their predictions can only be as good as TTIP is an "average" trade agreement as compared to previous RTAs. ${ }^{20}$

We adopt a different strategy to tackle the uncertainties concerning the outcome of the trade negotiations and the inherent difficulties to derive tariff equivalents for non-tariff barriers. We consider the range of conceivable symmetric reductions of non-tariff barriers between the EU and the US. We take great care to avoid that our symmetric reductions of NTBs would lead to subsidizing trade in any sector. To achieve this, we construct a Head and Ries index (see e.g. Head and Mayer 2014). We use this index along with our estimates of the $\theta_{k}$-parameters to derive an upper threshold for the potential relative reduction of trade barriers. This procedure, explained in detail in section A2 of the Appendix, leads to an estimate of a threshold of $9.97 \%$ for the most ambitious symmetric liberalization scenario. ${ }^{21}$ The assumption of symmetric liberalization is arbitrary, of course. We therefore complement our analysis with robustness checks involving the sectorally asymmetric liberalization paths considered by Francois et al. (2013), Fontagné et al. (2013) and Aichele et al. (2016).

Two issues have figured prominently in the scholarly debate on TTIP, liberalization in the service sector and possible spillover effects on third countries. Concerning the former, the experience from previous trade agreements shows that non-tariff barriers in the area of services are far more difficult to tackle and far less likely to be considerably reduced compared to those in the manufacturing sector. However, liberalization in the service sector is one of the major declared goals of the TTIP-partners, and the European Single Market shows that such liberalization is possible, in principle. Concerning the latter, it has been argued that a TTIP may have positive spillover effects on third countries due to regulatory convergence, i.e. exporters form third countries save on adaptation costs in serving EU and US-markets when the regulatory standards of the EU and the US converge. Moreover, apart from this direct effect there could be an indirect spillover if TTIP manages to set global standards and thereby also reduces the trade barriers between third countries. The evidence for such spillovers is weak and little can be said about their actual size, however (see Felbermayr et al. 2015). Because of the mentioned issues, our baseline estimate abstracts from spillover effects and from a specific provisions concerning service trade. We carry out detailed robustness checks for both, however.

\footnotetext{
${ }^{20}$ Not uncommonly, results for our sectoral RTA estimates supplied in table A3 in the appendix are mixed and include several negative values, though only positive values are significant. This reinforces our ambition to provide a range of possible outcomes of a TTIP instead of assuming effects to mimic average previous RTAs. ${ }^{21}$ Note that tariff equivalent barriers are given by $d_{n i k}-1$ and thus fall by more than $9.97 \%$ when $d_{\text {nik }}$ is reduced by that amount, with the exact percentage change depending on the initial level of the barrier.
} 


\section{The liberalization of transatlantic trade}

\subsection{Pure Trade Effects}

Real income changes - pure trade. Figure 1 reports our findings for the change in real incomes, $\widehat{V}_{n} \equiv V_{n}^{\prime} / V_{n}$ from eq. (25) for the pure trade scenario, $\hat{\lambda}_{n}^{j}=\lambda_{n}^{\prime j} / \lambda_{n}^{j}=1$ (no labor mobility in Europe). Real income gains within a TTIP are in a range of up to $0.46 \%$ for most countries even in the most ambitious scenario of trade barrier reductions of $9.97 \%$. The United States and Germany derive real income gains at around $0.32 \%$ and $0.37 \%$, respectively. Similar or slightly lower findings obtain, as shown, for France, as well as for Finland, Sweden, Denmark, and Hungary (not shown; see table A4 in the appendix for a full list of results). The real income gains of Belgium, the Netherlands, Great Britain and Malta are slightly higher. Ireland and Luxemburg (not shown) are outliers which would experience considerably higher welfare gains in this baseline simulations, with real income gains of $3.03 \%$ and $1.85 \%$, respectively. For the rest of the countries the quantitative effects are much smaller, even in this most ambitious scenario, with countries in the North-East and South of Europe such as Spain, Italy, Poland, Lithuania, or Romania gaining only between $0.08 \%$ and $0.16 \%$.

Figure 1 also shows that there are negative third-country effects due to trade diversion: China, Switzerland and Norway experience such negative welfare effects. Trade diversion is similarly strong for Russia, Korea and Taiwan as these countries are tightly integrated with the United States and the EU respectively but would not be involved in transatlantic trade liberalization. Negative effects on other third countries are negligible and there are even slight gains for Canada and the ROW.

In Figure 2 we have ordered EU countries according to their real income gains. It becomes apparent that the level of gains is closely related to the ex-ante spending share on US goods and services. Figure 2 reveals in addition that the limited overall welfare results, that we have diagnosed, stem from the small share that US goods have in overall spending in most countries. For the strongest winners Luxemburg and Ireland spending shares are in the range of $11 \%$ to $14 \%$ and for Belgium and the Netherlands at around 3\%. However, for the remaining EU members they are well below $2 \%$.

Figure 3 provides a detailed look into the fabrics of the real income changes. As is clear from eq. (17), real income is composed of nominal income, goods prices and land prices. A breakdown of the overall welfare change into the changes in goods prices, incomes and land 
Figure 1: Welfare effects of trade barrier reduction; pure trade regime

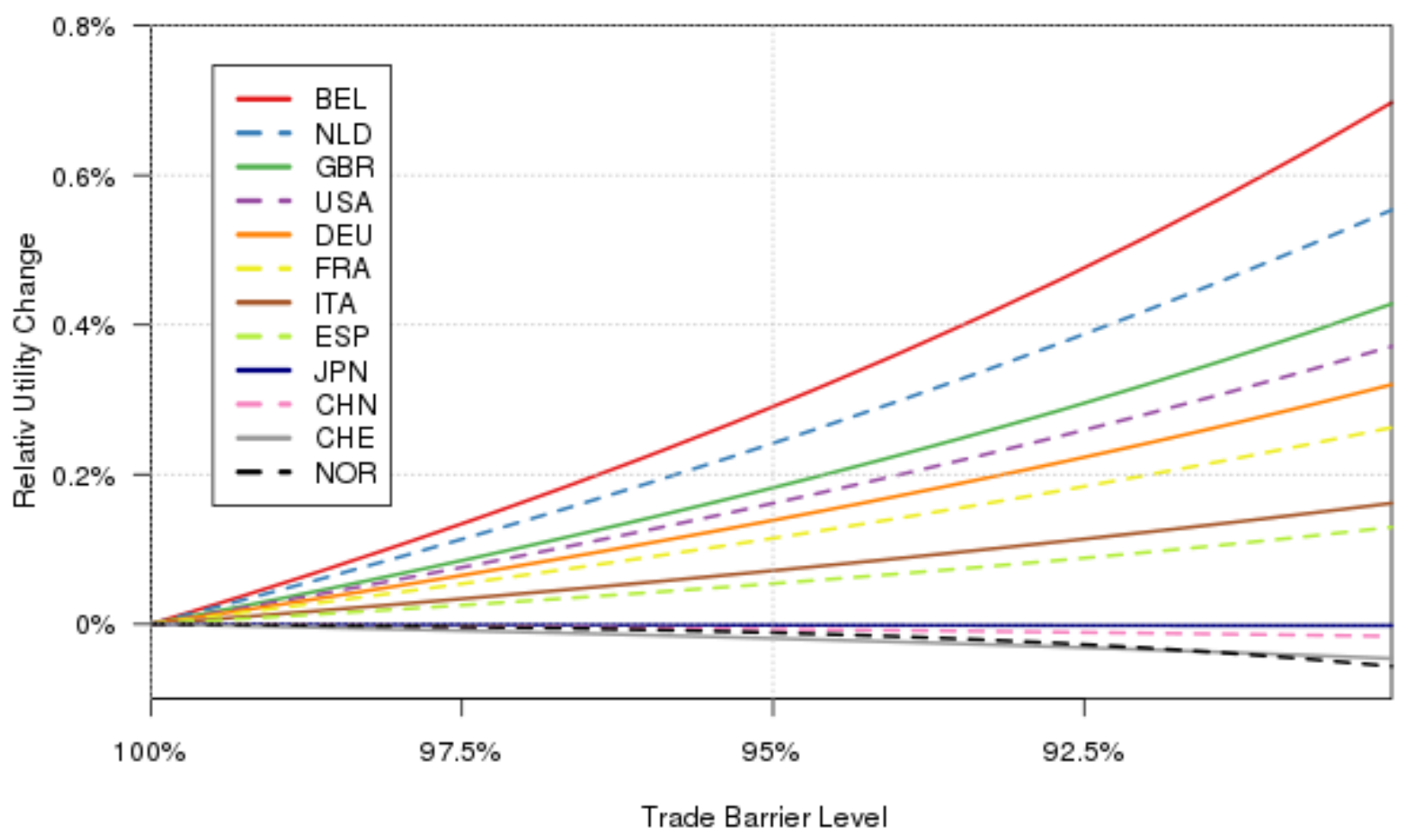

Figure 2: Welfare effects and initial spending shares with maximal liberalization

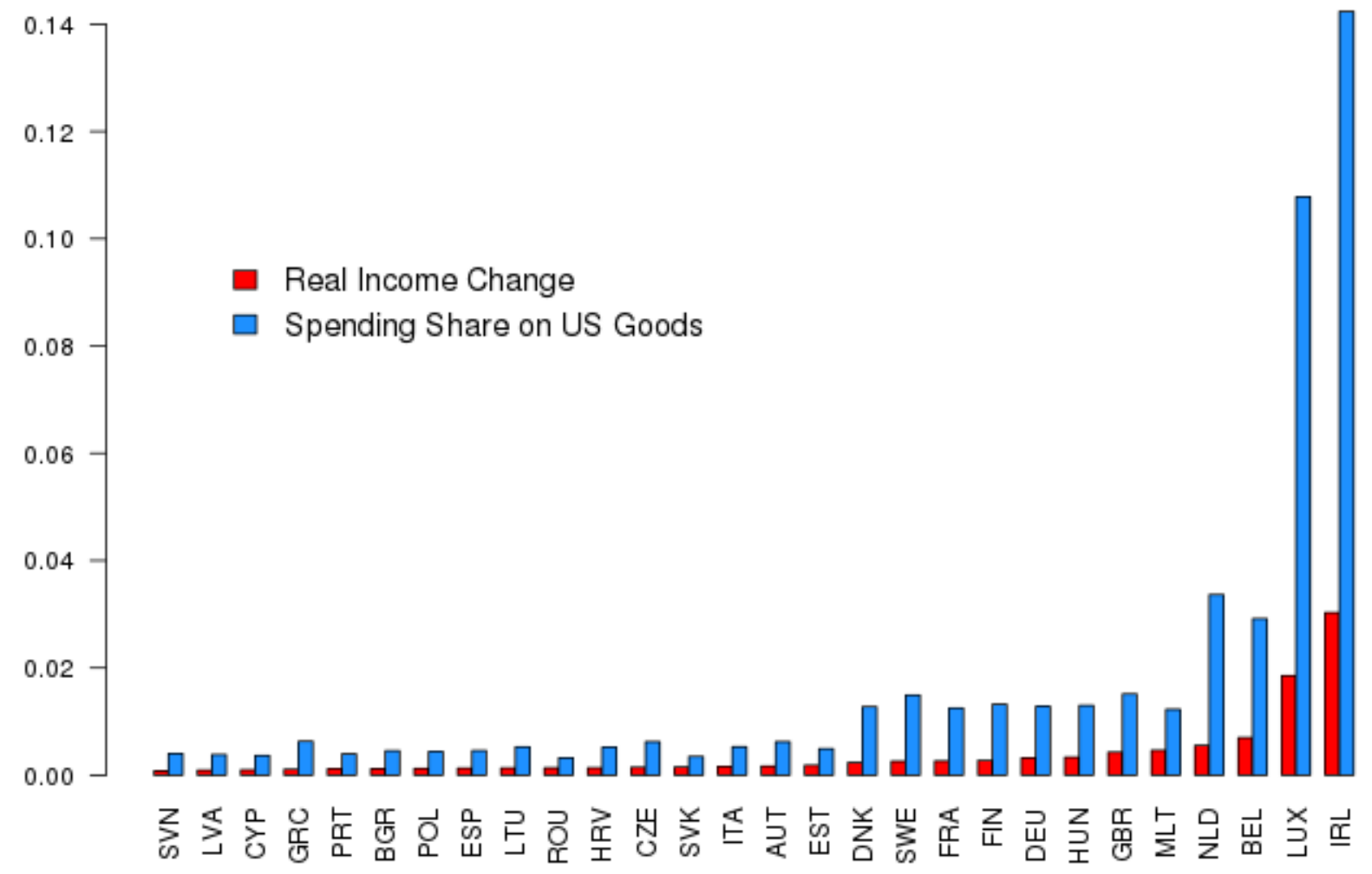

rents is provided in that figure. The numbers reported are for the most ambitious trade liberalization scenario. It is interesting to note that the overall welfare effects have very heterogeneous roots. For the USA and Great Britain, the overall welfare gain is due to a strong 
increase in wages which overcompensates rising goods and land prices. For Ireland, the Benelux countries and the large economies of Germany, France, Italy, and Spain both rising wages and falling prices drive welfare effects. Finally, the majority of Eastern and Southern European countries experience falling wages but benefit in real terms as goods and land prices fall. Finally, falling prices for both goods and land also buffer the negative effects of trade diversion in third party countries, resulting in only minimal welfare losses. In the cases of Canada, ROW and Brazil falling prices even lead to (marginal) real income gains despite reduced wages. Overall, our results suggest that economically more powerful countries in Europe can strengthen their nominal value added whereas weaker economies are hit by the increased competition and benefit only through falling prices.

Figure 3: The components of welfare changes with maximal liberalization
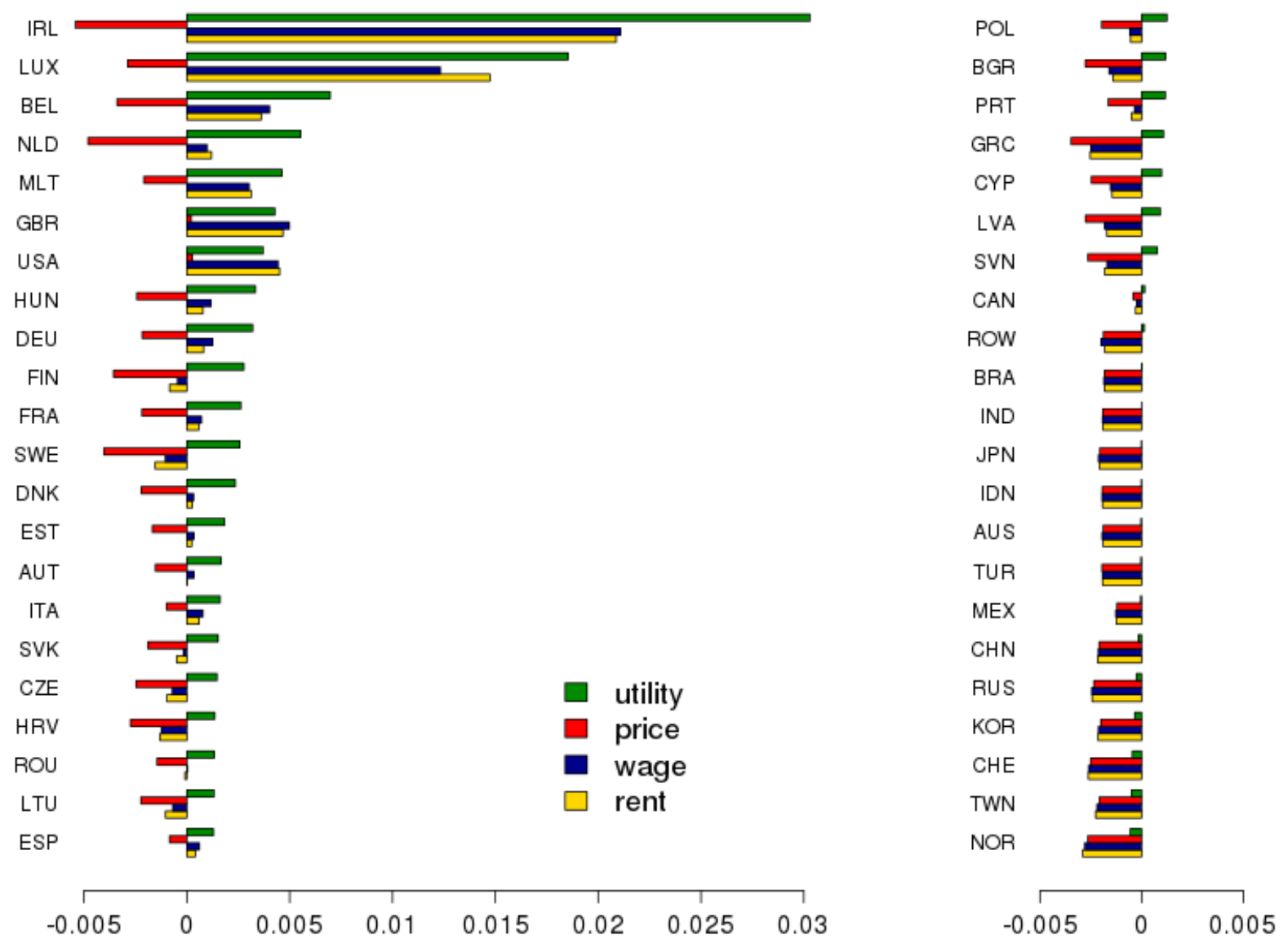

Industry effects. We have also looked at the changes in the industry mix (measured by production values) that are implied by transatlantic trade liberalization. Figure 4 reports the results on industry mix, again under the assumption of the most ambitious liberalization path. Germany is representative for many other countries in that there is only very little, if any, effect 
on the industry mix. The strongest changes occur in machinery, transport equipment and wholesale, which would expand under transatlantic trade liberalization, whilst telecommunications and transport activities shrink. Ireland, which would be the overall winner in welfare terms, experiences strong effects, in some industries, however. Financial and insurance, telecommunications, chemical and pharmaceutical products, as well as the food and the construction sector would all experience a strong boost.

Figure 4: Effects on the industry mix: Germany vs. Ireland with maximal liberalization Industry mix DEU Industry mix IRL

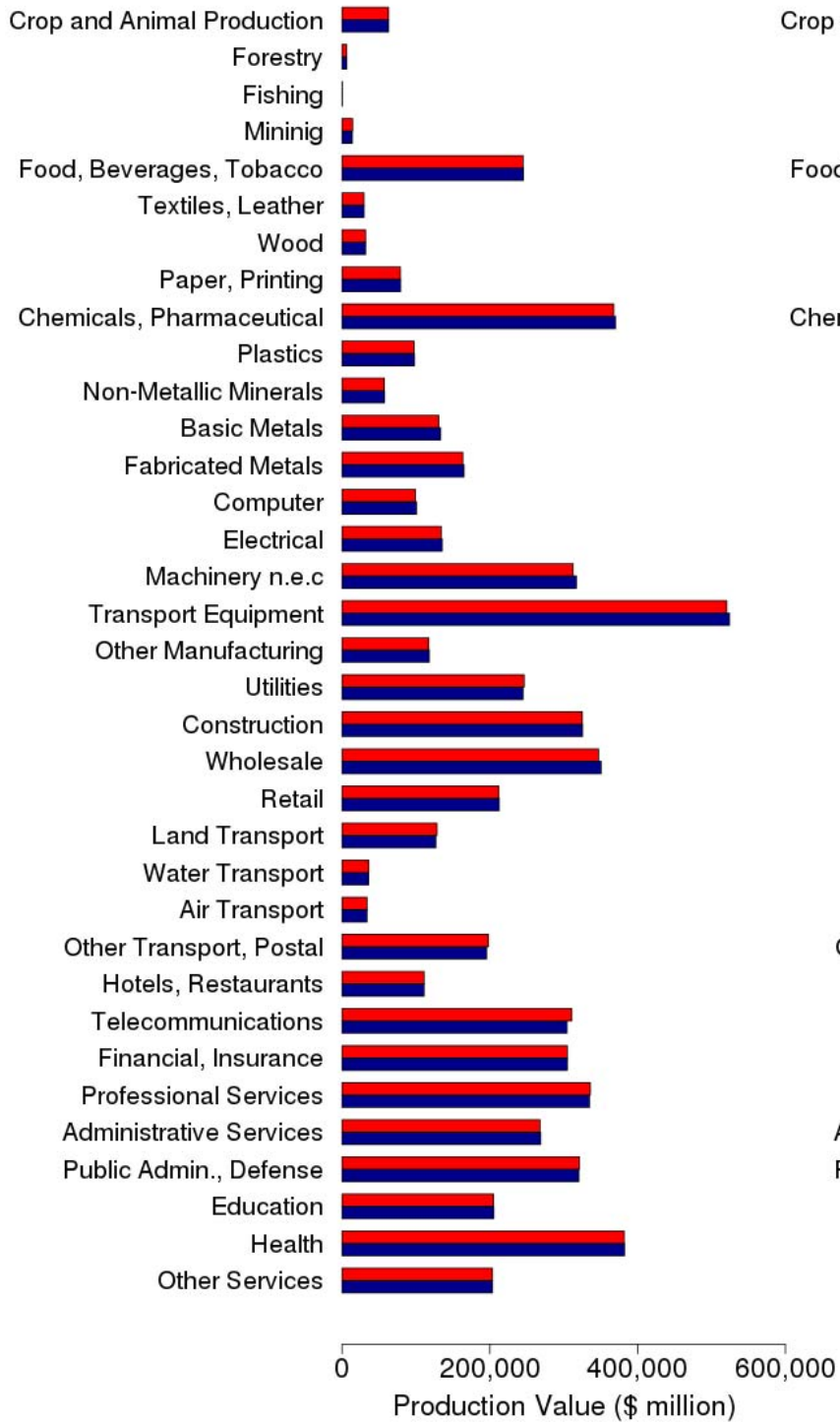

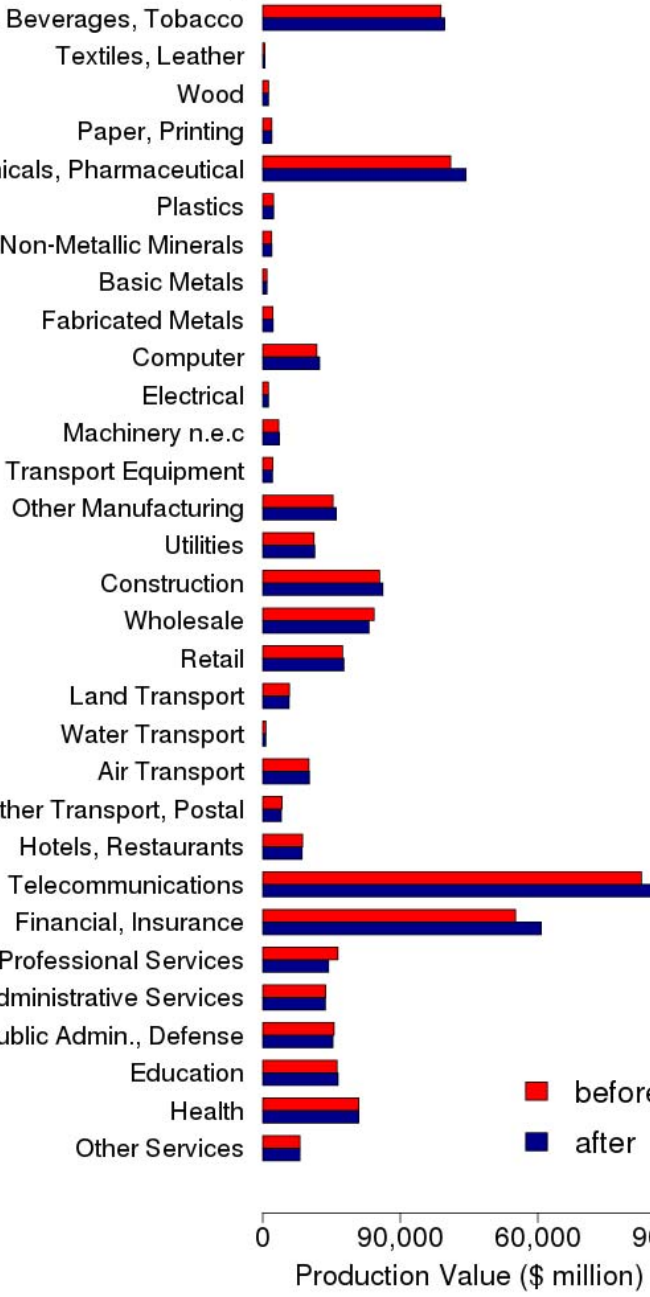

The role of land. A key innovation of our analysis in relation to previous studies of transatlantic trade liberalization is that we integrate land, notably as a consumption good, but also as a production factor. This has straightforward but very important consequences. This becomes clear from the following theoretical thought experiment. Suppose that land is only used for 
housing purposes, but not as an input in production $\left(\eta_{n k}=0\right)$. It then follows from our model that $r_{n} H_{n}=(1-\alpha) v_{n} L_{n}$ so that $\hat{r}_{n}=\hat{v}_{n}$ and $\hat{V}_{n}=\left(\hat{v}_{n} / \hat{P}_{n}\right)^{\alpha}$. Ignoring land in consumption ( $\alpha=1$ ) would thus lead to an overestimation of the welfare effects of the magnitude (1$\alpha) / \alpha$. For a value of the share of land in consumption of $1 / 10$, disregarding land in consumption hence implies an overestimation of real income effects in the range of $11.1 \%$.

Turning to the full model with land used as a consumption good and as an input in production, our numerical analyses suggest that real income effects of plausible TTIP-scenarios would be overestimated by about $9.49 \%$ for the USA and $9.36 \%$ percent for Germany, for example (see table A5 in the appendix). These simulations also reveal that the effects of disregarding land in production are by several magnitudes smaller compared to omitting land for housing. ${ }^{22}$

The upshot of this section is that a disregard of land leads to overestimates of the static real income effects of transatlantic trade liberalization. This is a key reason why we find more limited effects than previous analyses of a TTIP. It should also be pointed out that, by highlighting the role of land, our analysis contributes to the more general discussion of the sensitivity of the new quantitative trade models to auxiliary assumptions (see Costinot and Rodriguez-Claré 2014, section 5).

\subsection{The local perspective: German Counties}

Awareness of the local labor market consequences of shifts in the global economy has been growing recently both in public and in academics (e.g. Autor et al. 2013 and Caliendo et al. 2015). Public concern over transatlantic trade liberalization is similarly strong, in particular in Europe. It is therefore important to explore how local labor markets within countries are affected by a transatlantic deal. We take Germany as a case in point and trace the effects of trade liberalization down to the local level.

Data. For this purpose we use value added data from national accounts which is available on the regional level from the German federal and state statistical offices ("Regionaldatenbank der Statistischen Ämter des Bundes und der Länder"). This data is available for all 402 regions ("Kreise") disaggregated into 6 groups of NACE/ISIC industries which match directly with WIOD industries as can be seen in appendix A3. We label these sectors "Agriculture", "Manufacturing", which includes mining and raw materials, "Construction", "Trade", which includes transportation and tourism, "Financial" and "Government", which includes health and

\footnotetext{
${ }^{22}$ The effects become more pronounced, however, in the regime with population mobility, but are still small compared to the effects derived omitting land in consumption.
} 
education. Assuming that the German input output structure holds for all German regions we use production data to calculate intermediate demand and regional population data to spread consumption allowing us to rewrite the World Input Output table in terms of our new 6 sectors and including 402 German regions instead of the country as a whole. This method is explained in detail in section A3 in the appendix.

Descriptive evidence. The initial heterogeneity in the industry mix across locations is portrayed in Fig. A1 in the appendix. Regions in the Northwest and in the Northeast of Germany have the strongest focus on agriculture, though no region produces much more than $8.5 \%$ of its value added in this sector. Manufacturing, in contrast, is of bigger importance for locations in the South of Germany and especially for regions in which 3 major car manufacturers (VW, BMW and Mercedes) are active. In these locations it can be responsible for more than $80 \%$ of value added. The trade sector, which includes transportation, is most important for those regions that are close to the two major German airports (Frankfurt and Munich) or have large ports, like Hamburg. ${ }^{23}$ In and around Frankfurt where several important German banks, the largest German stock market and the German central bank are located, the financial sector plays a crucial role being responsible for up to $35 \%$ of total value added in these regions. The share of government tasks, including health and education, in value added is strongest in regions that consist of only one large city, and, in general, in the Northeast of Germany.

We also look at how important regions are for Germany as a whole. Fig. A2 in the appendix gives the share of a region's value added in a specific industry relative to Germany's value added in the industry. The largest agricultural producers are found in the Northwestern regions. All other sectors are, with some exceptions, dominated by the highly populated regions Berlin, Hamburg, Munich, "Region Hannover", and Cologne (all above one million inhabitants).

Transatlantic trade liberalization. We begin by calculating the effects of our maximum liberalization scenario between the US and all EU members without population mobility in order to show the heterogeneity of expected real income changes. The initial spending shares on US goods and the real income effects from the policy experiment on regions are shown in Figure 5. It is clear to see, that the initial share of a countries total spending on US goods (both final and intermediate) is again a very good indicator for its real income changes due to the barrier reduction. A key finding of our calculations is that despite their heterogeneity all regions win. This is remarkable, because our model, in principle, allows for negative welfare effects

\footnotetext{
${ }^{23}$ The outlier in the north west of Germany is „Landkreis Leer“, which has the second largest concentration of shipping companies after Hamburg.
} 
through terms of trade movements which work through wage adjustments across locations. The fear that TTIP might benefit only the already rich German locations at the cost of the poor ones is not supported by our analysis. Yet even in our ambitious scenario the potential gains are limited to between $0.31 \%$ and $0.71 \%$ of real income (figure A3 in the appendix provides a disaggregation of the real income effects).

Figure 5: Initial US Spending Shares and Real Income Changes with maximal liberalization

US Spending Share

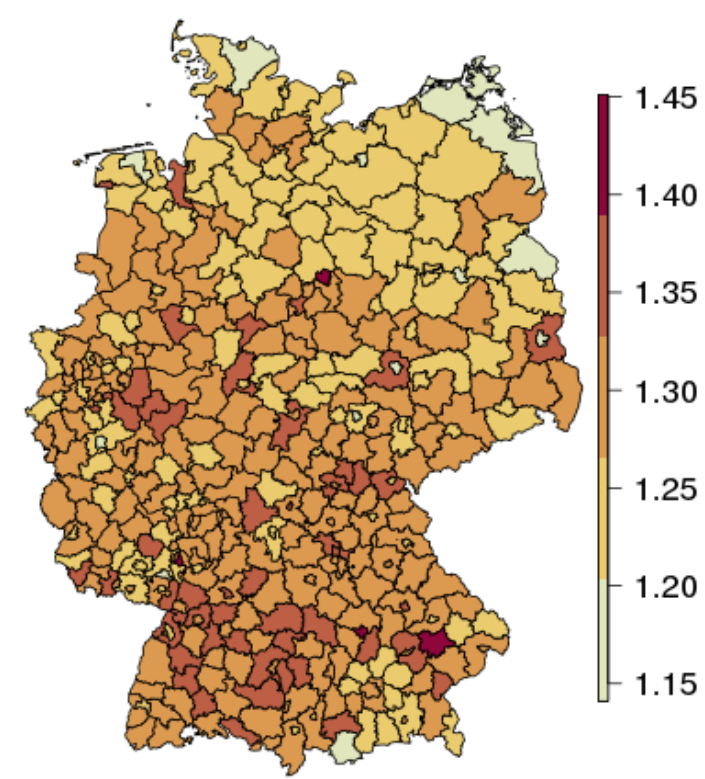

Real Income - Imobility

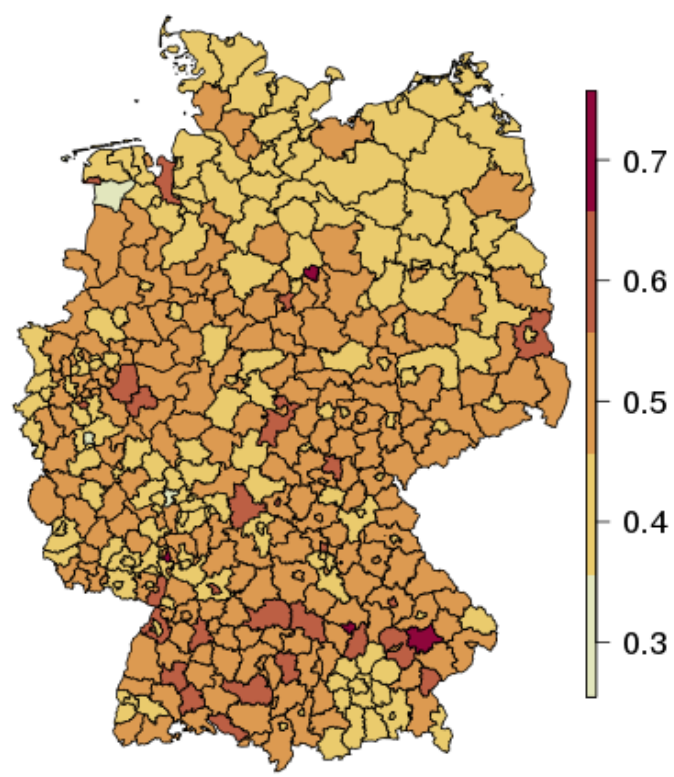

We show more detailed results for the case with population mobility among German regions (i.e. only in Germany not between other EU members) in Figure 6 below. Population losses are strongest in the North of Germany and population gains strongest in Southern Germany. Due to the low real income effects observed under population immobility the incentive to move is limited. The forecasted effects on population are consequently only in the range of $-0.39 \%$ to $0.62 \%$, despite our assumption of perfect mobility. The fear that individual German regions could experience strong population losses due to a restructuring thus also seems unwarranted.

The maps that depict population shifts and the evolution of rents provide a fairly similar picture. Intuitively, the (Northern) parts of Germany that shrink in population experience a fall in rents and the expanding (Southern) parts see rising rents. The predicted price increases for goods and services in the shrinking regions in the North reflect both higher wages (the marginal product of labor for the remaining population rises) and also higher trade costs, since a higher share of goods and services have to be imported from other counties. Price increases in expanding 
Southern counties can be rationalized by higher wages which are needed to compensate for higher rents. However, the predicted effects for both prices and wages are very low, in general.

Figure 6: Effects in the extreme scenario with population mobility and maximal liberalization
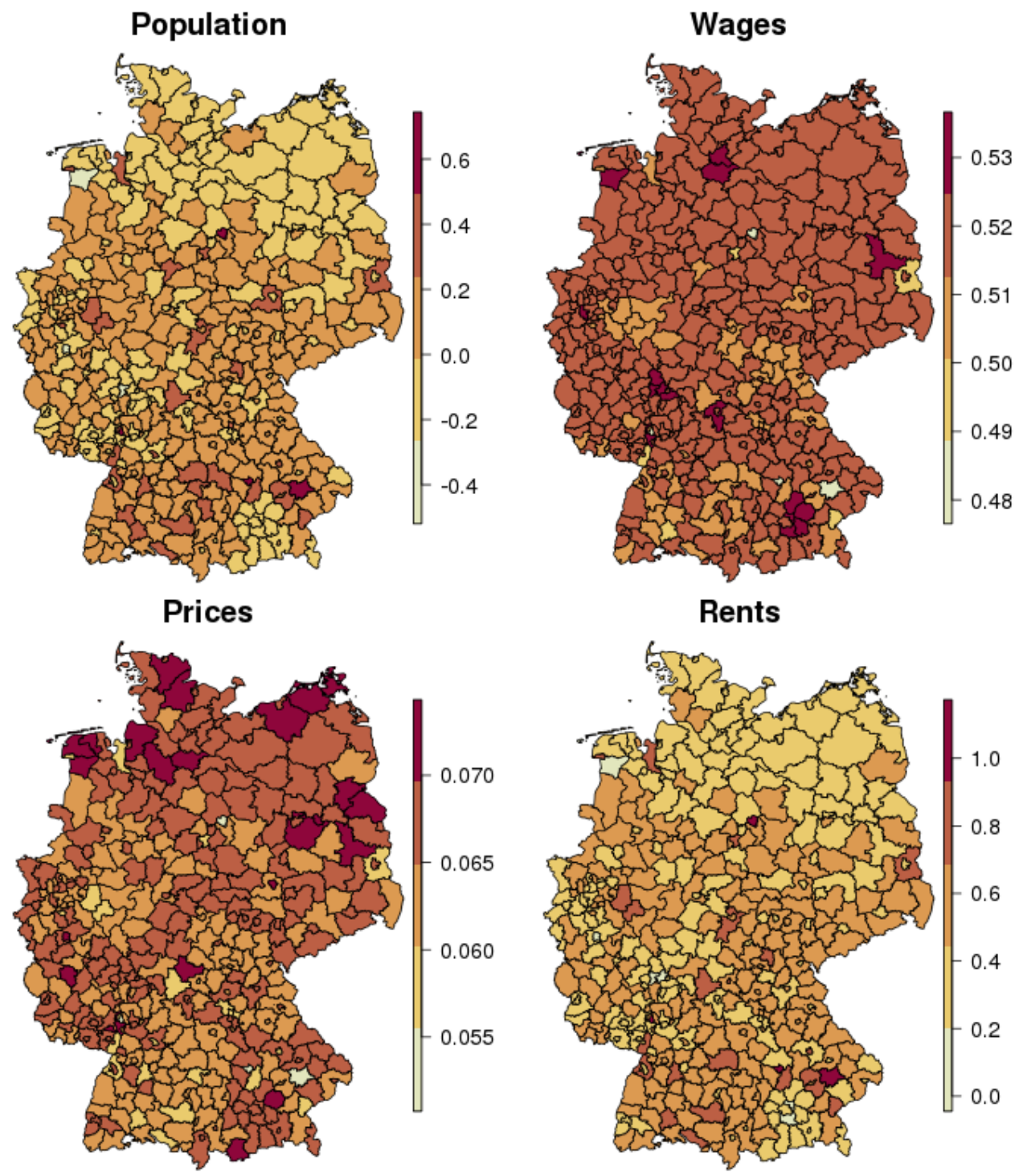

\subsection{Population mobility in Europe}

Figure 7 portrays our findings under the assumption of full labor mobility in the EU. It should be noted that our model captures only one dispersion force, scarce land, and hence land prices. Clearly, there are further forces which reduce labor mobility in Europe, in particular heterogeneous location preferences and a plethora of mobility costs which exceed those that prevail between German counties by far. The results in this section should therefore be seen as an extreme scenario, just as the no mobility case (depicted in figure 1) goes to the other extreme. The establishment of a spatial equilibrium in the mentioned extreme case would level income gains at $0.32 \%$ in all EU members. Ireland and Luxemburg would experience a strong inflow of labor followed, with an already much weaker inflow, by Belgium, the Netherlands, Great 
Britain, and Malta. The inflows immensely reduces wages in these countries, but thereby also lower production costs and consequently lead to much lower price increases as compared to the no-mobility case in figure 3. A close inspection of figure 7 reveals that the bulk of the adjustment to the spatial equilibrium within the European Union takes place through the adjustment of land prices.

Figure 7: Welfare effects in European countries, with labor mobility maximal liberalization
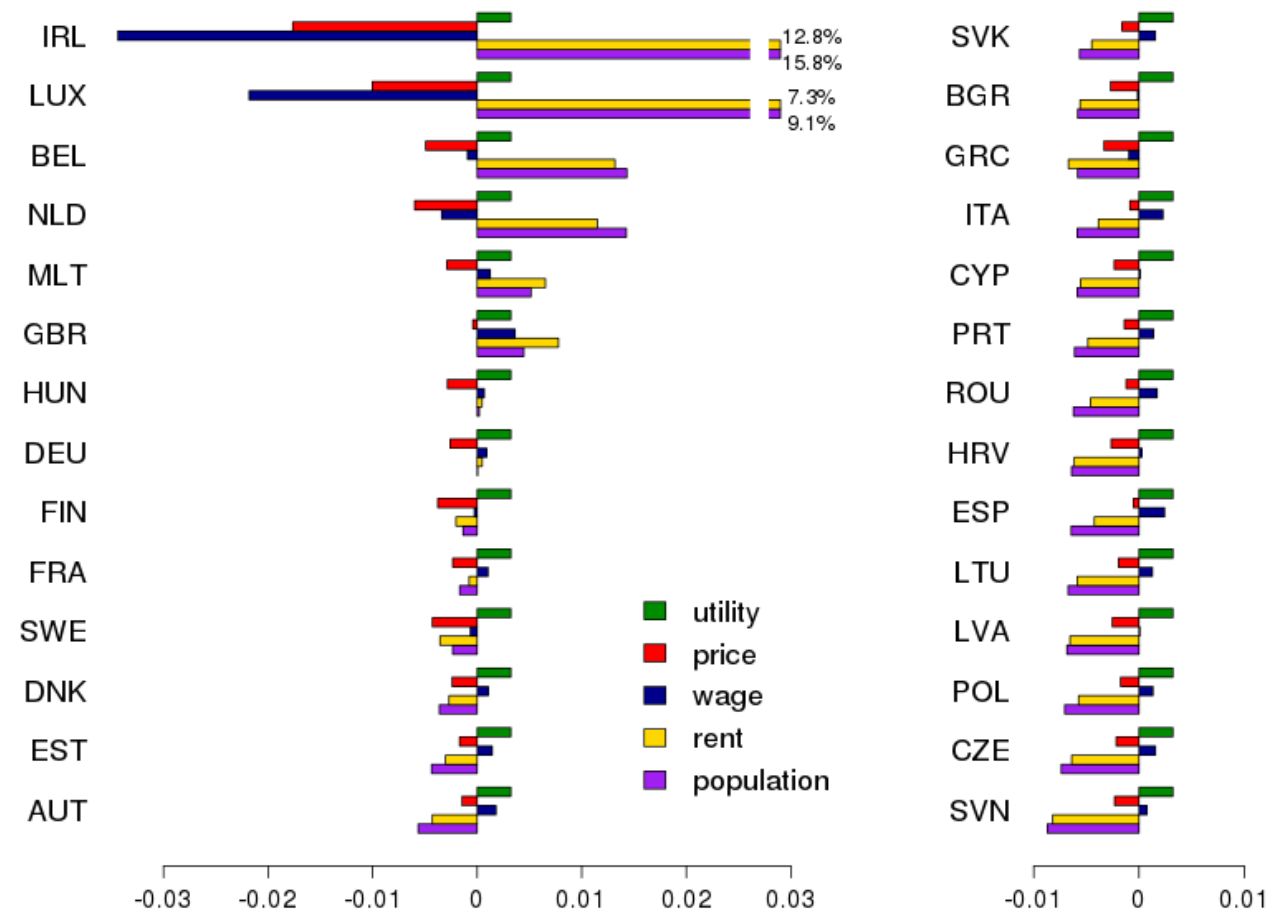

\subsection{TTIP versus multilateral trade liberalization}

An important concern regarding TTIP is that it may undermine the global trading system (Bagwell et al. 2016; Bhagwati et al. 2014; Panagariya 2013). Our analysis has in fact identified countries that lose due to trade diversion. An alternative to regional engagements would be to bring in more effort into the trade talks at the multilateral level, which are currently stalling. What level of multilateral trade liberalization would have to be achieved in order to match the real income effects that the European Union and the United States derive from a transatlantic deal? Redoing our calculations for a multilateral trade barrier reduction we find that the answer differs considerably between the two locations ${ }^{24}$. A multilateral reduction of trade barriers in the range of $0.5 \%$ to $1 \%$ would be enough for Europe ${ }^{25}$ to achieve the same welfare gains as in our most ambitious TTIP scenario. For the US, however, this would require a decrease in

24 See tables A6 and A7 in the appendix for detailed results.

25 In the case without population mobility this value, of course, varies across EU member states. However, as can be seen in table A6 in the appendix it remains in the range of $2 \%$ to $3 \%$ for most, including Germany. 
multilateral barriers of $2.5 \%$ to $3 . \%$. Consequently, the US appears to gain more from TTIP in comparison to a multilateral agreement, while the same does not necessarily hold true for the EU. This finding points to the importance of the Bhagwati's (1994) prediction that a 'hegemonic power' is likely to gain more by bargaining sequentially than simultaneously. Hence, TTIP might indeed harm the multilateral trading system by diverting the political energy of one of its key players, the US, away from WTO negotiations.

\subsection{Discussion: How deep ... ?}

Both our model and our empirical strategy differ from earlier studies of the transatlantic trade partnership. This section puts our results in perspective to previous research. In this section we also perform a variety of robustness checks including the effects of trade liberalization scenarios envisioned in these other studies within our model.

Comparison with previous studies. Our estimated welfare effects are within the range of two major CGE based studies. For maximal liberalization, we obtain similar effects of TTIP to those projected in Francois (2013) and Fontagné (2013), all methodological differences notwithstanding. Our results are lower than those reported in Egger et al. (2015) and similar to the lower end of their 95\% confidence interval, except for Ireland and Luxemburg which are in the range of their projected real income gains. The one-sector new quantitative trade study by Felbermayr et al. (2015) reports significantly higher welfare effects than we do. They find that the EU 28 would achieve a welfare gain of $3.9 \%$ and the United States of $4.9 \%$ while the welfare loss that they compute for the rest of the world is $-0.9 \%$. Aichele et al. (2016), drawing on a non-spatial Ricardian multi-industry model, also forecast higher welfare gains than we do.

Felbermayr et al. (2015) report that the member states at the EU periphery benefit most. This corresponds to our finding with respect to Ireland. However, we also find that a country at the geographic center, Luxemburg, would derive extremely strong benefits and that EU members in the Eastern periphery benefit less. On the other hand, Felbermayr et al. (2015) find that Spain would derive strong gains in the range of $5.6 \%$ which is strongly at odds with our findings and which is also hard to understand given the small share of spending that Spain devotes to US goods and services (cf. figure 2).

What explains these different results? Clearly, part is due to the fact that the estimates are based on different models which differ along several choices. Our analysis points to the importance of land in consumption and production and suggests that a disregard of land may imply an overestimation of the real income gains in the range of $10 \%$. Indeed, simply applying this margin to the average EU and the US welfare outcomes of Aichele et al. (2016), i.e. $0.43 \%$ and 
$0.49 \%$ pushes their results remarkably close to the level of welfare effects that we derive $(0.32 \%$ and $0.37 \%$ ). The real income gains projected by Felbermayr et al. (2015) would be reduced considerably but still remain higher than our findings. ${ }^{26}$ The welfare results of Egger et al. (2015) would also remain slightly higher than our effects. Second important reason for the divergence of results is due to the fact that different liberalization scenarios are considered. We address this issue in our robustness checks.

Robustness checks. We begin our robustness checks by discussing the results that we obtain with our model and method for the liberalization paths considered in Aichele et al. (2016), Francois et al. (2013) and Fontagné et al. (2013). To do so we extract the relative barrier changes implied by their reference scenarios and we perform a rough matching of sectors to our model. We report the welfare results of these exercises in table A 8 in the appendix. ${ }^{27}$

Start with the top down approach pursued by Aichele et al (2016). Their estimate of previous trade agreements implies that TTIP would result in very large barrier reductions for basic metals (with relative changes in barriers by more than $40 \%$ ), as well as mining and electrical equipment (both about $30 \%$ ) but have lower effects in the remaining industries and especially low effects in service industries $(4.8 \%$ to $9.2 \%)$. After matching their industry classification to ours we find the following. First, effects, both positive and negative, become more pronounced for most countries. In fact, the magnitude of welfare results is in the range of Egger et al. (2015) who rely on a similar method to establish their NTB reduction scenario. Second, we find that the large gains that Aichele et al. (2016) deduce for Croatia and which are absent in our symmetric approach now also appear and, thus, hinge critically on the assumed scenario. In contrast the strong gains in Ireland, Luxemburg, Belgium and the Netherland remain stable across scenarios. Third, the average long term effects for the EU with population mobility would be a real income gain of $1.28 \%$ and thus much higher than for our upper bound estimate of our across the board reduction $(0.32 \%)$. Our main result that effects are low except for some industries in some countries, remains intact, however.

Similar to our study, both Francois et al. (2013) and Fontagné et al. (2013) consider a symmetric scenario. However, since they approximate initial trade barriers, the symmetric reduction of these barriers implies an asymmetric relative reduction. The implied relative reductions are much smaller than in the case of Aichele et al. (2016) and more in line with our projected range, i.e. between $0.6 \%$ and $10.6 \%$ (unweighted average 2.7\%) for Francois et al. (2013) and between

\footnotetext{
${ }^{26}$ Felbermayr et al. (2015) assume that goods production represents all of an economy's activity. This assumption biases up results, as Egger et al. (2012) have shown (see the discussion in Egger et al. 2015:567).

${ }^{27}$ A supplementary appendix shows the sectoral matching for these scenarios.
} 
$0.1 \%$ and $14.9 \%$ (unweighted average 4.8\%) for Fontagné et al. (2013). Consequently, when comparing the results of our extreme scenario to their liberalization paths the latter lead to smaller effects $(0.2 \%$ and $0.14 \%$, respectively, compared to $0.32 \%$ in the mobile case $)$. It is reassuring to see that throughout all ambitious liberalization scenarios considered by these previous works, the welfare effects for Ireland and Luxemburg remain the highest and second highest, leading with similar margins over other countries.

We turn next to the effects of regulatory spillovers, a potential source of additional welfare gains as discussed in section 3.4. Since little can be said about the economic importance of such spillovers we adopt the standard approach (as in Francois et al. 2013, Felbermayr et al. 2015 and Egger et al. 2015) by assuming that for every 1\% trade barrier reduction between TTIP partners the barriers for third country exporters to the EU or the US are reduced by $0.2 \%$. In a separate scenario we additionally consider indirect spillovers that reduce trade barriers between and to third countries by $0.1 \%$ for every $1 \%$ reduction between TTIP partners. We report the welfare consequences of these scenarios with our maximal liberalization in Table A9 in the appendix. As can be seen, the effects on all members of TTIP of both direct and indirect spillovers are positive but generally small. Furthermore, the negative consequences of the TTIP shock for third countries are eliminated. However, positive effects are of noticeable magnitude across the board only under the extreme assumption that both direct and indirect spillovers prevail. As a further robustness check we consider the effects of asymmetric liberalization in the service and manufacturing sectors as discussed in section 3.4. Table A10 in the appendix reports the welfare results for our maximal liberalization scenario keeping trade barriers in either the finance sector or all service sectors at their original level. Taking only the finance sector out of the liberalization has little effect on the welfare gains of most countries. However, in line with the role of this sector in Luxemburg, the welfare gains in this country are reduced to one sixth from $1.85 \%$ to $0.32 \%$. While Ireland remains the strongest beneficiary its gains are also brought down considerably from $3.03 \%$ to $2.57 \%$. Taking the complete service sector out of the liberalization reduces the benefits for all members, driving welfare gains in Europe under population mobility from $0.32 \%$ to $0.17 \%$. Again, the most heavily affected countries are Ireland and Luxemburg. However, even in this scenario Ireland remains the strongest winner from TTIP with a gain in real income of $0.52 \%$, a result that we attribute to the observed very close ties of the Irish and US economies (cf. Figure 2).

Finally, we repeat these robustness checks to see how German counties are affected by the alternative liberalization paths. Table A11 in the appendix lists the range, mean and coefficient of variation for the "no service sector" liberalization and a spillover-scenario as in Francois et 
al. (2013). As can be seen, similar to our country results above, the different liberalization paths lead to lower welfare gains from TTIP.

\section{Conclusion}

This paper uses a static Ricardian new quantitative spatial trade model and employs the method of Dekle et al. (2007) to evaluate the quantitative consequences of the liberalization of transatlantic trade associated with the envisioned EU-US trade and investment partnership. The advantage of this approach is that we do not need information on the initial trade cost matrix to perform the numerical analysis. Trade costs are extremely hard to quantify since the most important outstanding trade barriers are of non-tariff nature. Previous analyses have obtained widely differing results for the tariff equivalents of these barriers and, hence, exhibit considerable uncertainties. Our approach allows us to circumvent this problem since these parameters are already embedded in the baseline specification. With our method it is easy to establish the real income effects for a whole range of trade cost reductions. Our extensive robustness checks reveal that, all detailed numbers notwithstanding, the qualitative effects associated with liberalization paths studied in previous works are very similar.

We provide new perspectives by highlighting the role of land for the estimation of real income effects, by looking at local labor markets and by addressing the mobility of labor.

Our results have to be seen against the background of three important caveats. First, our analysis sheds only light on the static gains from trade liberalization but not on the likely follow-up effects associated with induced capital accumulation and dynamic growth effects. The neglect of dynamic effects implies that we underestimate the full effects of trade liberalization. Second, for Europe we study a scenario both with no labor mobility and one with labor mobility hindered only by changing land prices. Both these scenarios are to be thought of as the extreme limiting cases. Third, our approach, like previous analyses of the transatlantic partnership, does not embrace the additional welfare effects associated with FDI. Embedding multinationals into our quantitative trade models and taking the effects of FDI on the EU, US and other countries into account is one avenue for future research. 


\section{References}

Aichele, Rahel, Gabriel Felbermayr and Inga Heiland (2016). Going Deep: The Trade and Welfare Effects of TTIP Revised, Ifo-Working Paper 219.

Alviarez, Vanessa (2015). Multinational Production and Sectoral Productivity Differences. University of British Columbia, mimeo.

Arkolakis, Costas, Natalia Ramondo, Andres Rodriguez-Claré and Stephen Yeaple (2014). Innovation and Production in the Global Economy. NBER Working Paper 18792.

Autor, David H., David Dorn, and Gordon H. Hanson (2013). The China Syndrome: Local Labor Market Effects of Import Competition in the United States. American Economic Review 103:6, 21212168

Bagwell, Kyle, Chad P. Bown and Robert W. Staiger (2016). Is the WTO Passé? Journal of Economic Literature 54:4, 1125-1231.

Bhagwati, Jagdish (1994). Threats to the World Trading System: Income Distribution and the Selfish Hegemon, Journal of International Affairs, Spring 1994

Bhagwati, Jagdish (2013). Dawn of a New System. Finance and Development, 8-13

Bhagwati, Jagdish, Pravin Krishna and Arvind Panagariya (2014). The World Trade System: Trends and Challenges, Paper presented at the Conference on Trade and Flag: The Changing Balance Of Power in the Multilateral Trade System, April 7-8, 2014, International Institute for Strategic Studies, Bahrain

Baier, Scott L. and Jeffrey H. Bergstrand (2007): Do Free Trade Agreements Actually Increase Members' International Trade? Journal of International Economics 71:1, 72-95.

Brainard, S. Lael (1997). An Empirical Assessment of the Proximity-Concentration Trade-off Between Multinational Sales and Trade, American Economic Review 87:4, 520-544

Caliendo, Lorenzo and Fernando Parro (2015). Estimates of the Trade and Welfare Effects of NAFTA. Review of Economic Studies 82, 1-44.

Caliendo, Lorenzo, Maximiliano Dvorkin and Fernando Parro (2015). The Impact of Trade on Labor Market Dynamics. Working Papers 2015-9, Federal Reserve Bank of St. Louis.

Caliendo, Lorenzo, Fernando Parro, Esteban Rossi-Hansberg and Pierre-Daniel G. Sarte (2014). The Impact of Regional and Sectoral Productivity Changes on the U.S. Economy. International Finance Discussion Papers 1119, Board of Governors of the Federal Reserve System (U.S.).

Costinot, Arnaud and Andrés Rodriguez-Claré (2014). Trade Theory with Numbers: Quantifying the Consequences of Globalization. Handbook of International Economics Vol 4, 197-261

Dekle, Robert, Jonathan Eaton and Samuel Kortum (2007). Unbalanced Trade. American Economic Review 97:2, 351-355.

Davis, Morris A. and François Ortalo-Magné (2011). Household expenditures, wages, rents. Review of Economic Dynamics 14:2, 248-261.

Eaton, Jonathan and Samuel Kortum (2002). Technology, Geography, and Trade. Econometrica 70:5, 1741-1779.

Ecorys (2009). Non-Tariff Measures in EU-US Trade and Investment - An Economic Analysis. Report, prepared by K. Berden, J.F. Francois, S. Tamminen, M. Thelle, and P. Wymenga for the European Commission, Reference OJ 2007/S180-219493.

Egger, Peter, Joseph Francois, Miriam Manchin and Doug Nelson (2015). Non-Tariff Barriers, Integration, and the Trans-Atlantic Economy, Economic Policy, 30 (83), 539-584

Egger, Peter, Mario Larch and Kevin E. Staub (2012). Trade Preferences and Bilateral Trade in Goods and Services: A Structural Approach, CEPR Discussion Papers 9501 
Egger, Peter and Sergey Nigai (2015): Structural Gravity with Dummies Only: Constrained ANOVAType Estimation of Gravity Models. Journal of International Economics 97:1, 86-99.

Erumban, Abdul Azeez, Reitze Gouma, Gaaitzen de Vries, Klaas de Vries and Marcel Timmer (2012). WIOD Socio-Economic Accounts (SEA): Sources and Methods, April, Mimeo

Felbermayr, Gabriel, Benedikt Heid, Mario Larch and Erdal Yalcin (2015). Macroeconomic Potentials of Transatlantic Free Trade: A High Resolution Perspective for Europe and the World, Economic Policy 30 (83), 491-537.

Felbermayr, Gabriel, Mario Larch, Lisandra Flach, Erdal Yalcin and Sebastian Benz (2013). Dimensionen und Auswirkungen eines Freihandelsabkommens zwischen der EU und den USA. Final Report, Ifo Institute Munich.

Fontagné, Lionel, Amélie Guillin and Cristina Mitaritonna (2011). Estimations of Tariff Equivalents for the Services Sectors. Working Papers 2011-24, CEPII research center.

Fontagné, Lionel, Julien Gourdon and Sébastien Jean (2013). Transatlantic Trade: Whither Partnership, Which Economic Consequences? CEPII Policy Brief, CEPII, Paris.

Francois, Joseph, Miriam Manchin, Hanna Norberg, Olga Pindyuk, Patrick Tomberger (2013). Reducing Transatlantic Barriers to Trade and Investment: An Economic Assessment. Report TRADE10/A2/A16 for the European Commissions, IIDE and CEPR.

Fujita, Masahisa and Jacques-Francois Thisse (2013). Economics of Agglomeration. Cities, Industrial Location, and Regional Growth. Second Edition. Cambridge University Press.

Hamilton, Daniel and Joseph Quinlan (2014). The Transatlantic Economy 2014. Center for Transatlantic Relations Johns Hopkins University. Paul H. Nitze School of Advanced International Studies.

Haufler, Andreas and Michael Pflüger (2004). International Commodity Taxation under Monopolistic Competition. Journal of Public Economic Theory 6(3), 445-470.

Haufler, Andreas and Michael Pflüger (2007). International Oligopoly and the Taxation of Commerce with Revenue Constrained Governments. Economica 74, 451-473.

Head, Keith and Thierry Mayer (2014). Gravity Equations: Workhorse, Toolkit, and Cookbook. Handbook of International Economics Vol 4, 131-195.

Helpman, Elhanan (1998). The size of regions. In: Pines, D., Sadka, E., Zilcha, I. (Eds.), Topics in Public Economics. Theoretical and Empirical Analysis. Cambridge University Press, $33-$ 54.

Helpman, Elhanan and Paul Krugman (1985). Market Structure and Foreign Trade. MIT-Press.

Kee, Hiau Looi, Alessandro Nicita and Marcelo Olarreaga (2009). Estimating Trade Restrictiveness Indices. Economic Journal 119:534, 172-199.

Langhammer, Rolf J., Daniel Piazolo and Horst Siebert (2002). Assessing Proposals for a Transatlantic Free Trade Area, Aussenwirtschaft 57, 161-185.

Lawrence Robert Z. (1996). Regionalism, Multilateralism and Deeper Integration. Washington: Brookings Institution.

Michaels, Guy, Ferdinand Rauch and Stephen J. Redding (2012). Urbanization and Structural Transformation. Quarterly Journal of Economics 127:2, 535-586.

O'Mahony, Mary and Marcel P. Timmer (2009). Output, Input and Productivity Measures at the Industry Level: The EU KLEMS Database. The Economic Journal 119:538, 374-403.

Ossa, Ralph (2014): Trade Wars and Trade Talks with Data. American Economic Review 104:12, 4104-4146.

Panagariya, Arvind (2013). Challenges to the Multilateral Trading System and Possible Responses. Economics: The Open Access, Open-Assessment E-Journal, 2013-3. 
Pflüger, Michael (2001). Ecological Dumping Under Monopolistic Competition. Scandinavian Journal of Economics, 103:4, 689-706.

Pflüger, Michael and Jens Südekum (2013). Subsidizing Firm Entry in Open Economies. Journal of Public Economics, 97:1, 258-271.

Pflüger, Michael and Takatoshi Tabuchi (2011). The Size of Regions with Land Use for Production. Regional Science and Urban Economics 40: 481-489.

Ramondo, Natalia and Andres Rodriguez-Claré (2013). Trade, Multinational Production, and the Gains from Openness. Journal of Political Economy, 121(2), 273-322.

Ramondo, Natalia and Andres Rodriguez-Claré and Milagro Saborio-Rodriguez (2014). Trade, Domestic Frictions, and Scale Effects. Mimeo, revised version of NBER Working Paper 18532.

Redding, Stephen J. (2014). Goods Trade, Factor Mobility and Welfare. Mimeo, Princeton.

Redding, Stephen J. (2016). Goods Trade, Factor Mobility and Welfare. Journal of International Economics, 101, 148-167.

Santos Silva, J. M. C. and Silvana Tenreyro (2006): The Log of Gravity. The Review of Economics and Statistics 88:4, 641-658.

Santos Silva, J. M. C. and Silvana Tenreyro (2011): Further Simulation Evidence on the Performance of the Poisson Pseudo-Maximum Likelihood Estimator. Economics Letters 112:2, 220-222.

Statistisches Bundesamt (2011). Wirtschaft und Statistik 5/2011.

Timmer, Marcel P., Erik Dietzenbacher, Bart Los, Rober Stehrer and Gaaitzen J. de Vries (2015). An Illustrated User Guide to the World Input-Output Database: the Case of Global Automotive Production. Review of International Economics 23:3, 575-605.

Timmer, Marcel P., Bart Los, Robert Stehrer, and Gaaitzen J. de Vries (2016). An Anatomy of the Global Trade Slowdown based on the WIOD 2016 Release. GGDC Research Memorandum 162.

Valentinyi, Akos and Berthold Herrendorf (2008). Measuring Factor Income Shares at the Sector Level. Review of Economic Dynamics 11:4, 820-835.

van Ark, Bart (2005). THE EU KLEMS PROJECT - Towards an Integrated System of Growth, Productivity and National Accounts for the European Union. OECD Workshop on Productivity Measurement. Madrid, Spain.

Yotov, Yoto V., Roberta Piermartini, José-Antonio Monteiro, and Mario Larch (2016): An Advanced Guide to Trade Policy Analysis: The Structural Gravity Model. WTO and UNCTAD.

Piermartini, Roberta and Yoto V. Yotov (2016): Estimating trade policy effects with structural gravity. WTO Staff Working Paper, No. ERSD-2016-1. 


\section{Appendix}

Table A1: $\quad$ List of Sectors

Table A2: Country Sample

Table A3: $\quad$ Estimation of $\theta_{k}-$ full results

Table A4: Detailed effects in the extreme scenario

Table A5: The significance of land

Table A6: Multilateral Liberalization - no mobility

Table A7: Multilateral Agreements - mobility within the EU

Table A8: $\quad$ Real income effects of alternative scenarios

Table A9: $\quad$ Real income effects and spillovers (maximal liberalization)

Table A10: Real income effects and service trade (maximal liberalization)

Table A11: Summary of German regional effects

Figure A1: Shares of different industries in the region's total production

Figure A2: Shares of a regions' industry production in Germany's total industry production

Figure A3: Regional disaggregation, immobile population

App A1: Derivation of trade shares from the WIOD database

App A2: Trade Barriers - Robustness check

App A3: Derivation of regional trade data; table of regional sectors 


\section{Table A1: List of sectors}

\begin{tabular}{|c|c|c|c|}
\hline \multicolumn{2}{|c|}{ WIOD } & \multicolumn{2}{|c|}{ Our Paper } \\
\hline Sectc & Label & \multicolumn{2}{|c|}{ Sector Label } \\
\hline 1 & Crop and animal production, hunting and related service activities & 1 & Crop, Animal Production \\
\hline 2 & Forestry and logging & 2 & Forestry \\
\hline 3 & Fishing and aquaculture & 3 & Fishing \\
\hline 4 & Mining and quarrying & 4 & Mininig \\
\hline 5 & Food products, beverages and tobacco products & 5 & Food, Beverages, Tobacco \\
\hline 6 & Textiles, wearing apparel and leather products & 6 & Textiles, Leather \\
\hline 7 & Wood, cork, except furniture; articles of straw and plaiting materials & 7 & Wood \\
\hline 8 & Paper and paper products & \multirow{2}{*}{8} & \multirow{2}{*}{ Paper, Printing } \\
\hline 9 & Printing and reproduction of recorded media & & \\
\hline 10 & Coke and refined petroleum products & \multirow{3}{*}{9} & \multirow{3}{*}{ Chemicals, Pharmaceuticals } \\
\hline 11 & Chemicals and chemical products & & \\
\hline 12 & Basic pharmaceutical products and pharmaceutical preparations & & \\
\hline 13 & Rubber and plastic products & 10 & Plastics \\
\hline 14 & Other non-metallic mineral products & 11 & Non-Metallic Minerals \\
\hline 15 & Basic metals & 12 & Basic Metals \\
\hline 16 & Fabricated metal products, except machinery and equipment & 13 & Fabricated Metals \\
\hline 17 & Computer, electronic and optical products & 14 & Computer \\
\hline 18 & Electrical equipment & 15 & Electrical \\
\hline 19 & Machinery and equipment n.e.c. & 16 & Machinery n.e.c \\
\hline 20 & Motor vehicles, trailers and semi-trailers & 17 & \multirow{2}{*}{ Transport Equipment } \\
\hline 21 & Other transport equipment & 18 & \\
\hline 22 & Furniture; other manufacturing & & \multirow{2}{*}{ Other Manufacturing } \\
\hline 23 & Repair and installation of machinery and equipment & 19 & \\
\hline 24 & Electricity, gas, steam and air conditioning supply & \multirow{4}{*}{20} & \multirow{3}{*}{ Utilities } \\
\hline 25 & Water collection, treatment and supply & & \\
\hline 26 & Sewerage; waste collection, treatment and disposal activities; & & \\
\hline 27 & Construction & & Construction \\
\hline 28 & Wholesale, retail trade $\&$ repair of motor vehicles and motorcycles & 21 & \multirow{2}{*}{ Wholesale } \\
\hline 29 & Wholesale trade, except of motor vehicles and motorcycles & 22 & \\
\hline 30 & Retail trade, except of motor vehicles and motorcycles & & Retail \\
\hline 31 & Land transport and transport via pipelines & 23 & Land Transport \\
\hline 32 & Water transport & 24 & Water Transport \\
\hline 33 & Air transport & 25 & Air Transport \\
\hline 34 & Warehousing and support activities for transportation & 26 & \multirow{2}{*}{ Other Transport, Postal } \\
\hline 35 & Postal and courier activities & 27 & \\
\hline 36 & Accommodation and food service activities & & Hotels, Restaurants \\
\hline 37 & Publishing activities & \multirow{4}{*}{$\begin{array}{l}28 \\
29\end{array}$} & \multirow{4}{*}{ Telecommunications } \\
\hline 38 & $\begin{array}{l}\text { Motion picture, video and television programme production, sound } \\
\text { recording and music publishing activities; broadcasting activities }\end{array}$ & & \\
\hline 39 & Telecommunications & & \\
\hline 40 & Computer programming, consultancy; information service activities & & \\
\hline 41 & Financial service activities, except insurance and pension funding & \multirow{3}{*}{30} & \multirow{3}{*}{ Financial, Insurance } \\
\hline 42 & Insurance, pension funding, except compulsory social security & & \\
\hline 43 & Activities auxiliary to financial services and insurance activities & & \\
\hline 44 & Legal, accounting activities; head offices; management consultancy & \multirow{5}{*}{31} & \multirow{5}{*}{ Professional Services } \\
\hline 45 & Architectural and engineering activities; technical testing and analysis & & \\
\hline 46 & Scientific research and development & & \\
\hline 47 & Advertising and market research & & \\
\hline 48 & Other professional, scientific, technical activities; veterinary activities & & \\
\hline 49 & Administrative and support service activities & & Administrative Services \\
\hline 50 & Public administration and defence; compulsory social security & 32 & Public Admin., Defense \\
\hline 51 & Education & 33 & Education \\
\hline 52 & Human health and social work activities & 34 & Health \\
\hline 53 & Other service activities & & \\
\hline 54 & $\begin{array}{l}\text { Activities of households as employers; undifferentiated goods- and } \\
\text { services-producing activities of households for own use }\end{array}$ & 35 & Other Services \\
\hline 55 & Activities of extraterritorial organizations and bodies & & \\
\hline
\end{tabular}


Table A2: Country sample

\begin{tabular}{ll} 
Code & Country \\
AUS & Australia \\
AUT & Austria \\
\hline BEL & Belgium \\
BGR & Bulgaria \\
BRA & Brazil \\
CAN & Canada \\
CHE & Switzerland \\
CHN & China \\
CYP & Cyprus \\
CZE & Czech Republic \\
DEU & Germany \\
DNK & Denmark \\
\hline ESP & Spain \\
EST & Estonia \\
FIN & Finland \\
\hline
\end{tabular}

\begin{tabular}{|ll|}
\hline Code & Country \\
\hline FRA & France \\
\hline GBR & Great Britain \\
\hline GRC & Greece \\
HRV & Croatia \\
HUN & Hungary \\
IDN & Indonesia \\
\hline IND & India \\
\hline IRL & Ireland \\
\hline ITA & Italy \\
\hline JPN & Japan \\
\hline KOR & Korea \\
\hline LTU & Lithuania \\
LUX & Luxemburg \\
LVA & Latvia \\
MEX & Mexico \\
\hline
\end{tabular}

\begin{tabular}{ll} 
Code & Country \\
MLT & Malta \\
\hline NLD & Netherlands \\
NOR & Norway \\
POL & Poland \\
PRT & Portugal \\
ROU & Romania \\
RUS & Russia \\
SVK & Slovakia \\
SVN & Slovenia \\
SWE & Sweden \\
TUR & Turkey \\
TWN & Taiwan \\
USA & United States of America \\
ROW & Rest of World \\
\hline
\end{tabular}

Source: WIOD Database 
Table A3: Estimation of $\theta_{k}-$ full results

\begin{tabular}{|c|c|c|c|c|c|c|}
\hline Industry & $\theta_{k}$ & z-ratio & RTA & z-ratio & $\mathrm{N}$ & Pseudo $\mathrm{R}^{2}$ \\
\hline Crop and Animal Production & $1.121 * *$ & 2.088 & -0.053 & -0.637 & 22907 & 0.9947 \\
\hline Forestry & $4.204^{* *}$ & 2.090 & -0.484 & -1.631 & 8642 & 0.9973 \\
\hline Fishing & $3.824 *$ & 1.703 & -0.123 & -0.597 & 8715 & 0.9926 \\
\hline Mininig & $22.683 * * *$ & 2.956 & -0.072 & -0.443 & 14628 & 0.9906 \\
\hline Food, Beverages, Tobacco & $1.128 * * *$ & 3.148 & -0.023 & -0.387 & 27721 & 0.9914 \\
\hline Textiles, Leather & 1.023 & 1.587 & $0.437 * *$ & 1.992 & 29976 & 0.9959 \\
\hline Wood & $2.648 * * *$ & 3.970 & $0.228 * * *$ & 2.732 & 18641 & 0.9977 \\
\hline Paper, Printing & $2.955 * * *$ & 5.123 & 0.065 & 1.471 & 20544 & 0.9979 \\
\hline Chemicals, Pharmaceutical & $2.151 * *$ & 2.120 & 0.069 & 0.747 & 29244 & 0.9924 \\
\hline Plastics & $1.410 * * *$ & 3.669 & -0.078 & -1.470 & 26631 & 0.9983 \\
\hline Non-Metallic Minerals & $3.651 * * *$ & 6.410 & -0.076 & -1.125 & 22096 & 0.9945 \\
\hline Basic Metals & $4.150 * * *$ & 3.068 & $0.347 * * *$ & 3.278 & 20233 & 0.9805 \\
\hline Fabricated Metals & $2.269 * * *$ & 3.584 & $0.174 * * *$ & 3.404 & 26966 & 0.9970 \\
\hline Computer & $3.273^{* *}$ & 2.058 & 0.100 & 0.861 & 30452 & 0.9974 \\
\hline Electrical & $2.770 * * *$ & 4.827 & $0.094 *$ & 1.663 & 28250 & 0.9986 \\
\hline Machinery n.e.c & $3.309 * * *$ & 3.917 & $0.124 *$ & 1.694 & 29691 & 0.9982 \\
\hline Transport Equipment & $1.011 * *$ & 2.527 & $0.298 * * *$ & 3.490 & 25764 & 0.9980 \\
\hline Other Manufacturing & $2.597 * * *$ & 3.795 & $0.383 * *$ & 2.052 & 27356 & 0.9985 \\
\hline Utilities & $14.30 * * *$ & 6.235 & 0.029 & 0.116 & 13095 & 0.9904 \\
\hline
\end{tabular}

${ }^{*} \mathrm{p}<0.1 ;{ }^{* *} \mathrm{p}<0.05 ;{ }^{* *} \mathrm{p}<0.01 ;$ Pseudo $\mathrm{R}^{2}$ is the square of correlation between fitted values and data. 
Table A4: Detailed effects in the extreme scenario

\begin{tabular}{|c|c|c|c|c|c|c|c|c|c|}
\hline & \multicolumn{2}{|c|}{ real income } & \multicolumn{2}{|c|}{ prices } & \multicolumn{2}{|c|}{ wages } & \multicolumn{2}{|c|}{ rents } & \multirow{2}{*}{$\begin{array}{l}\text { popu- } \\
\text { lation }\end{array}$} \\
\hline & nmobile & mobile & nmobile & mobile & immobile & mobile & immobile & mobile & \\
\hline AUS & $0,00 \%$ & $0,00 \%$ & $-0,19 \%$ & $-0,23 \%$ & $-0,19 \%$ & $-0,23 \%$ & $-0,19 \%$ & $-0,23 \%$ & $0,00 \%$ \\
\hline AUT & $0,17 \%$ & $0,32 \%$ & $-0,15 \%$ & $-0,15 \%$ & $0,03 \%$ & $0,18 \%$ & $0,00 \%$ & $-0,43 \%$ & $-0,56 \%$ \\
\hline BEL & $0,70 \%$ & $0,32 \%$ & $-0,34 \%$ & $-0,49 \%$ & $0,40 \%$ & $-0,09 \%$ & $0,36 \%$ & ,32\% & $1,43 \%$ \\
\hline BGR & $0,12 \%$ & $0,32 \%$ & $-0,28 \%$ & $-0,27 \%$ & $-0,16 \%$ & $-0,01 \%$ & $-0,14 \%$ & $-0,56 \%$ & $-0,58 \%$ \\
\hline BRA & $0,00 \%$ & $0,00 \%$ & $-0,18 \%$ & $-0,22 \%$ & $-0,19 \%$ & $-0,22 \%$ & $-0,18 \%$ & $-0,22 \%$ & $0,00 \%$ \\
\hline CAN & $0,02 \%$ & $0,02 \%$ & $-0,04 \%$ & $-0,07 \%$ & $-0,02 \%$ & $-0,05 \%$ & $-0,03 \%$ & $-0,06 \%$ & $0,00 \%$ \\
\hline CHE & $-0,05 \%$ & $-0,03 \%$ & $-0,25 \%$ & $-0,30 \%$ & $-0,26 \%$ & $-0,29 \%$ & $-0,26 \%$ & $-0,29 \%$ & $0,00 \%$ \\
\hline $\mathrm{CHN}$ & $-0,02 \%$ & $-0,02 \%$ & $-0,21 \%$ & $-0,25 \%$ & $-0,21 \%$ & $-0,25 \%$ & $-0,22 \%$ & $-0,25 \%$ & $0,00 \%$ \\
\hline CYP & $0,10 \%$ & $0,32 \%$ & $-0,25 \%$ & $-0,24 \%$ & $-0,15 \%$ & $0,01 \%$ & $-0,15 \%$ & $-0,55 \%$ & $-0,59 \%$ \\
\hline CZE & $0,15 \%$ & $0,32 \%$ & $-0,25 \%$ & $-0,22 \%$ & $-0,07 \%$ & $0,16 \%$ & $-0,10 \%$ & $-0,64 \%$ & $-0,74 \%$ \\
\hline DEU & $0,32 \%$ & $0,32 \%$ & $-0,22 \%$ & $-0,26 \%$ & $0,13 \%$ & $0,09 \%$ & $0,08 \%$ & $0,05 \%$ & $0,00 \%$ \\
\hline DNK & $0,24 \%$ & $0,32 \%$ & $-0,22 \%$ & $-0,24 \%$ & $03 \%$ & $0,11 \%$ & $0,03 \%$ & $-0,2$ & $-0,36 \%$ \\
\hline ESP & $0,13 \%$ & $0,32 \%$ & $-0,08 \%$ & $-0,05 \%$ & $0,06 \%$ & $0,24 \%$ & $0,04 \%$ & $-0,42 \%$ & $-0,64 \%$ \\
\hline EST & $0,18 \%$ & $0,32 \%$ & $-0,17 \%$ & $-0,17 \%$ & $0,03 \%$ & $0,14 \%$ & $0,02 \%$ & & $-0,44 \%$ \\
\hline FIN & $0,28 \%$ & $0,32 \%$ & $-0,36 \%$ & $-0,38 \%$ & $-0,05 \%$ & $-0,03 \%$ & $-0,08 \%$ & $-0,20 \%$ & $-0,14 \%$ \\
\hline FRA & $0,26 \%$ & $0,32 \%$ & $-0,22 \%$ & $-0,23 \%$ & $0,07 \%$ & $0,10 \%$ & $0,06 \%$ & $-0,08 \%$ & $-0,17 \%$ \\
\hline GBR & $0,43 \%$ & $0,32 \%$ & $0,02 \%$ & $-0,04 \%$ & $0,50 \%$ & $0,36 \%$ & $0,47 \%$ & $0,78 \%$ & $0,45 \%$ \\
\hline GRC & $0,11 \%$ & $0,32 \%$ & $-0,35 \%$ & $-0,33 \%$ & $-0,25 \%$ & $-0,10 \%$ & $-0,25 \%$ & $-0,67 \%$ & $-0,58 \%$ \\
\hline HRV & $\%$ & $0,32 \%$ & $-0,27 \%$ & $-0,2$ & $2 \%$ & $3 \%$ & & -0 & \\
\hline HUN & $0,33 \%$ & $0,32 \%$ & $-0,24 \%$ & $-0,29 \%$ & $0,12 \%$ & $0,07 \%$ & $0,08 \%$ & $0,05 \%$ & $0,02 \%$ \\
\hline IDN & $0,00 \%$ & $0,00 \%$ & $-0,19 \%$ & $-0,23 \%$ & $-0,19 \%$ & $-0,23 \%$ & $\%$ & & $0,00 \%$ \\
\hline IND & $0,00 \%$ & $0,00 \%$ & $-0,19 \%$ & $-0,23 \%$ & $-0,19 \%$ & $-0,23 \%$ & $-0,19 \%$ & $-0,2$ & $0,00 \%$ \\
\hline IRL & $3,03 \%$ & $0,32 \%$ & $-0,54 \%$ & $-1,76 \%$ & $2,11 \%$ & $-3,44 \%$ & $2,09 \%$ & $12,78 \%$ & $15,82 \%$ \\
\hline ITA & $0,16 \%$ & $0,32 \%$ & $-0,10 \%$ & $-0,09 \%$ & $0,08 \%$ & $0,23 \%$ & & $9 \%$ & $-0,59 \%$ \\
\hline JPN & $0,00 \%$ & $0,00 \%$ & $-0,21 \%$ & $-0,24 \%$ & $-0,21 \%$ & $-0,24 \%$ & $-0,21 \%$ & $-0,24 \%$ & $0,00 \%$ \\
\hline KOR & $-0,03 \%$ & $-0,04 \%$ & $-0,20 \%$ & $-0,24 \%$ & $-0,21 \%$ & $-0,25 \%$ & $-0,21 \%$ & & $0,00 \%$ \\
\hline LTU & $0,13 \%$ & $0,32 \%$ & $-0,22 \%$ & $-0,20 \%$ & $-0,07 \%$ & $0,13 \%$ & $-0,10 \%$ & $-0,59 \%$ & $-0,67 \%$ \\
\hline LUX & $1,85 \%$ & $0,32 \%$ & $-0,29 \%$ & $-1,00 \%$ & $1,23 \%$ & $-2,18 \%$ & $1,47 \%$ & $\%$ & $9,05 \%$ \\
\hline LVA & $0,09 \%$ & $0,32 \%$ & $-0,28 \%$ & $-0,25 \%$ & $-0,18 \%$ & $0,01 \%$ & $-0,17 \%$ & $-0,66 \%$ & $-0,69 \%$ \\
\hline MEX & $0,00 \%$ & $0,00 \%$ & $-0,12 \%$ & $-0,15 \%$ & $-0,13 \%$ & $-0,15 \%$ & $-0,12 \%$ & $-0,15 \%$ & $0,00 \%$ \\
\hline MLT & $0,46 \%$ & $0,32 \%$ & $-0,21 \%$ & $-0,29 \%$ & $0,30 \%$ & $0,12 \%$ & & & $0,52 \%$ \\
\hline NLD & $0,55 \%$ & $0,32 \%$ & $-0,48 \%$ & $-0,60 \%$ & $0,10 \%$ & $-0,34 \%$ & $0,12 \%$ & $1,15 \%$ & $1,43 \%$ \\
\hline NOR & $-0,06 \%$ & $-0,06 \%$ & $-0,26 \%$ & $-0,31 \%$ & $-0,28 \%$ & $-0,33 \%$ & $-0,2$ & & $0,00 \%$ \\
\hline POL & $0,12 \%$ & $0,32 \%$ & $-0,20 \%$ & $-0,18 \%$ & $-0,06 \%$ & $0,13 \%$ & $-0,05 \%$ & $-0,57 \%$ & $-0,71 \%$ \\
\hline PRT & $0,12 \%$ & $0,32 \%$ & $-0,16 \%$ & $-0,14 \%$ & $-0,03 \%$ & $0,14 \%$ & $-0,05 \%$ & $-0,49 \%$ & $-0,61 \%$ \\
\hline ROU & $0,13 \%$ & $0,32 \%$ & $-0,15 \%$ & $-0,12 \%$ & $0,00 \%$ & $0,17 \%$ & $-0,01 \%$ & $-0,46 \%$ & $-0,62 \%$ \\
\hline RUS & $-0,03 \%$ & $-0,03 \%$ & $-0,23 \%$ & $-0,27 \%$ & $-0,25 \%$ & $-0,28 \%$ & $-0,24 \%$ & $-0,28 \%$ & $0,00 \%$ \\
\hline SVK & $0,15 \%$ & $0,32 \%$ & $-0,19 \%$ & $-0,16 \%$ & $-0,02 \%$ & $0,16 \%$ & $-0,05 \%$ & $-0,45 \%$ & $-0,57 \%$ \\
\hline SVN & $0,08 \%$ & $0,32 \%$ & $-0,26 \%$ & $-0,23 \%$ & $-0,17 \%$ & $0,08 \%$ & $-0,18 \%$ & $-0,82 \%$ & $-0,87 \%$ \\
\hline SWE & $0,26 \%$ & $0,32 \%$ & $-0,40 \%$ & $-0,43 \%$ & $-0,10 \%$ & $-0,07 \%$ & $-0,15 \%$ & $-0,36 \%$ & $-0,23 \%$ \\
\hline TUR & $0,00 \%$ & $0,00 \%$ & $-0,19 \%$ & $-0,23 \%$ & $-0,19 \%$ & $-0,22 \%$ & $-0,19 \%$ & $-0,23 \%$ & $0,00 \%$ \\
\hline TWN & $-0,05 \%$ & $-0,05 \%$ & $-0,21 \%$ & $-0,25 \%$ & $-0,22 \%$ & $-0,26 \%$ & $-0,23 \%$ & $-0,27 \%$ & $0,00 \%$ \\
\hline USA & $0,37 \%$ & $0,38 \%$ & $0,03 \%$ & $0,01 \%$ & $0,44 \%$ & $0,43 \%$ & $0,45 \%$ & $0,44 \%$ & $0,00 \%$ \\
\hline ROW & $0,01 \%$ & $0,03 \%$ & $-0,19 \%$ & $-0,23 \%$ & $-0,20 \%$ & $-0,23 \%$ & $-0,18 \%$ & $-0,21 \%$ & $0,00 \%$ \\
\hline
\end{tabular}


Table A5: The significance of land

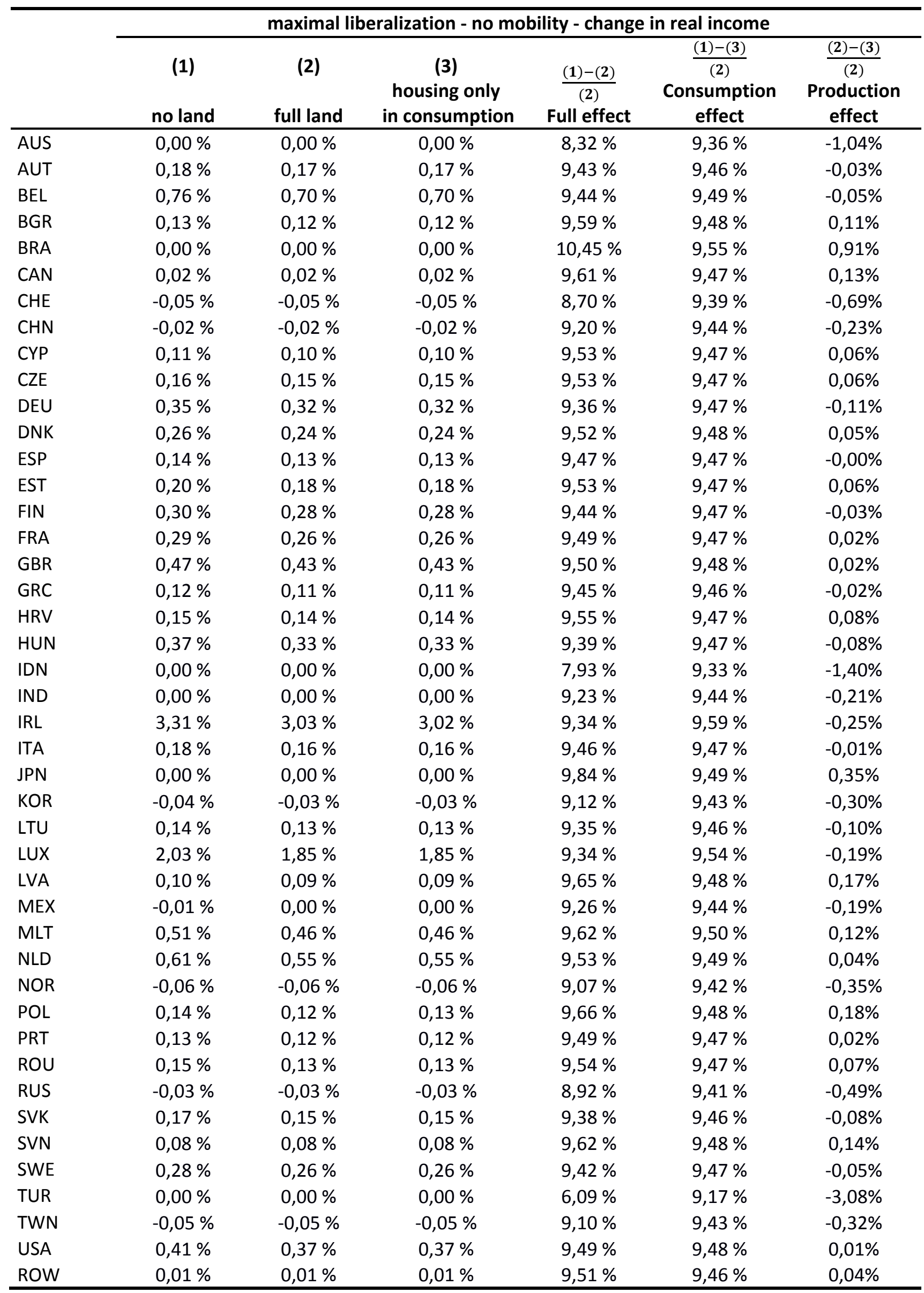


Table A6: Multilateral Liberalization - no mobility

\begin{tabular}{|c|c|c|c|c|c|c|}
\hline & \multicolumn{6}{|c|}{ Real income effects for multilateral trade barrier reductions by } \\
\hline & $0.5 \%$ & $1 \%$ & $1.5 \%$ & $2 \%$ & $2.5 \%$ & $3 \%$ \\
\hline AUS & $0,14 \%$ & $0,29 \%$ & $0,44 \%$ & $0,60 \%$ & $0,76 \%$ & $0,92 \%$ \\
\hline AUT & $0,24 \%$ & $0,49 \%$ & $0,74 \%$ & $1,00 \%$ & $1,26 \%$ & $1,53 \%$ \\
\hline BEL & $0,35 \%$ & $0,70 \%$ & $1,06 \%$ & $1,43 \%$ & $1,81 \%$ & $2,20 \%$ \\
\hline BGR & $0,32 \%$ & $0,65 \%$ & $0,99 \%$ & $1,34 \%$ & $1,70 \%$ & $2,07 \%$ \\
\hline BRA & $0,08 \%$ & $0,16 \%$ & $0,24 \%$ & $0,32 \%$ & $0,41 \%$ & $0,50 \%$ \\
\hline CAN & $0,21 \%$ & $0,41 \%$ & $0,63 \%$ & $0,84 \%$ & $1,06 \%$ & $1,29 \%$ \\
\hline $\mathrm{CHE}$ & $0,23 \%$ & $0,47 \%$ & $0,72 \%$ & $0,97 \%$ & $1,22 \%$ & $1,48 \%$ \\
\hline $\mathrm{CHN}$ & $0,05 \%$ & $0,11 \%$ & $0,17 \%$ & $0,22 \%$ & $0,28 \%$ & $0,34 \%$ \\
\hline CYP & $0,28 \%$ & $0,56 \%$ & $0,85 \%$ & $1,14 \%$ & $1,44 \%$ & $1,75 \%$ \\
\hline CZE & $0,33 \%$ & $0,67 \%$ & $1,02 \%$ & $1,37 \%$ & $1,73 \%$ & $2,10 \%$ \\
\hline DEU & $0,19 \%$ & $0,39 \%$ & $0,58 \%$ & $0,79 \%$ & $0,99 \%$ & $1,20 \%$ \\
\hline DNK & $0,24 \%$ & $0,47 \%$ & $0,72 \%$ & $0,96 \%$ & $1,21 \%$ & $1,47 \%$ \\
\hline ESP & $0,15 \%$ & $0,30 \%$ & $0,45 \%$ & $0,61 \%$ & $0,77 \%$ & $0,93 \%$ \\
\hline EST & $0,37 \%$ & $0,74 \%$ & $1,12 \%$ & $1,50 \%$ & $1,90 \%$ & $2,30 \%$ \\
\hline FIN & $0,18 \%$ & $0,36 \%$ & $0,54 \%$ & $0,73 \%$ & $0,92 \%$ & $1,11 \%$ \\
\hline FRA & $0,15 \%$ & $0,31 \%$ & $0,47 \%$ & $0,63 \%$ & $0,79 \%$ & $0,96 \%$ \\
\hline GBR & $0,16 \%$ & $0,33 \%$ & $0,50 \%$ & $0,68 \%$ & $0,86 \%$ & $1,04 \%$ \\
\hline GRC & $0,15 \%$ & $0,30 \%$ & $0,45 \%$ & $0,60 \%$ & $0,76 \%$ & $0,92 \%$ \\
\hline HRV & $0,27 \%$ & $0,54 \%$ & $0,82 \%$ & $1,11 \%$ & $1,40 \%$ & $1,71 \%$ \\
\hline HUN & $0,37 \%$ & $0,75 \%$ & $1,14 \%$ & $1,53 \%$ & $1,94 \%$ & $2,35 \%$ \\
\hline IDN & $0,14 \%$ & $0,27 \%$ & $0,42 \%$ & $0,56 \%$ & $0,71 \%$ & $0,86 \%$ \\
\hline IND & $0,08 \%$ & $0,15 \%$ & $0,24 \%$ & $0,32 \%$ & $0,41 \%$ & $0,51 \%$ \\
\hline IRL & $0,57 \%$ & $1,15 \%$ & $1,74 \%$ & $2,35 \%$ & $2,97 \%$ & $3,60 \%$ \\
\hline ITA & $0,12 \%$ & $0,24 \%$ & $0,36 \%$ & $0,49 \%$ & $0,61 \%$ & $0,74 \%$ \\
\hline JPN & $0,10 \%$ & $0,19 \%$ & $0,29 \%$ & $0,39 \%$ & $0,50 \%$ & $0,60 \%$ \\
\hline KOR & $0,18 \%$ & $0,37 \%$ & $0,56 \%$ & $0,75 \%$ & $0,95 \%$ & $1,16 \%$ \\
\hline LTU & $0,31 \%$ & $0,63 \%$ & $0,95 \%$ & $1,28 \%$ & $1,62 \%$ & $1,96 \%$ \\
\hline LUX & $1,06 \%$ & $2,15 \%$ & $3,27 \%$ & $4,41 \%$ & $5,57 \%$ & $6,77 \%$ \\
\hline LVA & $0,29 \%$ & $0,59 \%$ & $0,89 \%$ & $1,20 \%$ & $1,51 \%$ & $1,83 \%$ \\
\hline MEX & $0,15 \%$ & $0,29 \%$ & $0,44 \%$ & $0,59 \%$ & $0,74 \%$ & $0,90 \%$ \\
\hline MLT & $0,61 \%$ & $1,24 \%$ & $1,88 \%$ & $2,53 \%$ & $3,20 \%$ & $3,89 \%$ \\
\hline NLD & $0,36 \%$ & $0,72 \%$ & $1,09 \%$ & $1,47 \%$ & $1,85 \%$ & $2,24 \%$ \\
\hline NOR & $0,22 \%$ & $0,44 \%$ & $0,67 \%$ & $0,89 \%$ & $1,12 \%$ & $1,35 \%$ \\
\hline POL & $0,24 \%$ & $0,49 \%$ & $0,74 \%$ & $1,00 \%$ & $1,26 \%$ & $1,53 \%$ \\
\hline PRT & $0,19 \%$ & $0,39 \%$ & $0,59 \%$ & $0,80 \%$ & $1,00 \%$ & $1,22 \%$ \\
\hline ROU & $0,23 \%$ & $0,46 \%$ & $0,69 \%$ & $0,94 \%$ & $1,19 \%$ & $1,45 \%$ \\
\hline RUS & $0,20 \%$ & $0,40 \%$ & $0,60 \%$ & $0,81 \%$ & $1,02 \%$ & $1,23 \%$ \\
\hline SVK & $0,34 \%$ & $0,69 \%$ & $1,05 \%$ & $1,41 \%$ & $1,78 \%$ & $2,15 \%$ \\
\hline SVN & $0,31 \%$ & $0,62 \%$ & $0,94 \%$ & $1,26 \%$ & $1,60 \%$ & $1,94 \%$ \\
\hline SWE & $0,21 \%$ & $0,42 \%$ & $0,63 \%$ & $0,85 \%$ & $1,08 \%$ & $1,31 \%$ \\
\hline TUR & $0,17 \%$ & $0,35 \%$ & $0,53 \%$ & $0,71 \%$ & $0,89 \%$ & $1,07 \%$ \\
\hline TWN & $0,28 \%$ & $0,57 \%$ & $0,86 \%$ & $1,16 \%$ & $1,46 \%$ & $1,76 \%$ \\
\hline USA & $0,07 \%$ & $0,14 \%$ & $0,21 \%$ & $0,28 \%$ & $0,35 \%$ & $0,43 \%$ \\
\hline ROW & $0,21 \%$ & $0,42 \%$ & $0,64 \%$ & $0,87 \%$ & $1,09 \%$ & $1,33 \%$ \\
\hline
\end{tabular}


Table A7: Multilateral Liberalization - mobility within the EU

\begin{tabular}{|c|c|c|c|c|c|c|}
\hline & \multicolumn{6}{|c|}{ Real income effects for multilateral trade barrier reductions by } \\
\hline & $0.5 \%$ & $1 \%$ & $1.5 \%$ & $2 \%$ & $2.5 \%$ & $3 \%$ \\
\hline AUS & $0,14 \%$ & $0,29 \%$ & $0,44 \%$ & $0,60 \%$ & $0,76 \%$ & $0,92 \%$ \\
\hline AUT & $0,21 \%$ & $0,43 \%$ & $0,66 \%$ & $0,88 \%$ & $1,11 \%$ & $1,35 \%$ \\
\hline BEL & $0,21 \%$ & $0,43 \%$ & $0,66 \%$ & $0,88 \%$ & 1,11 \% & $1,35 \%$ \\
\hline$B G R$ & $0,21 \%$ & $0,43 \%$ & $0,66 \%$ & $0,88 \%$ & $1,11 \%$ & $1,35 \%$ \\
\hline BRA & $0,08 \%$ & $0,16 \%$ & $0,24 \%$ & $0,32 \%$ & $0,41 \%$ & $0,50 \%$ \\
\hline CAN & $0,21 \%$ & $0,41 \%$ & $0,63 \%$ & $0,84 \%$ & $1,06 \%$ & $1,29 \%$ \\
\hline $\mathrm{CHE}$ & $0,24 \%$ & $0,48 \%$ & $0,73 \%$ & $0,98 \%$ & $1,24 \%$ & $1,50 \%$ \\
\hline $\mathrm{CHN}$ & $0,05 \%$ & $0,11 \%$ & $0,17 \%$ & $0,22 \%$ & $0,28 \%$ & $0,34 \%$ \\
\hline CYP & $0,21 \%$ & $0,43 \%$ & $0,66 \%$ & $0,88 \%$ & 1,11 \% & $1,35 \%$ \\
\hline CZE & $0,21 \%$ & $0,43 \%$ & $0,66 \%$ & $0,88 \%$ & $1,11 \%$ & $1,35 \%$ \\
\hline DEU & $0,21 \%$ & $0,43 \%$ & $0,66 \%$ & $0,88 \%$ & 1,11 \% & $1,35 \%$ \\
\hline DNK & $0,21 \%$ & $0,43 \%$ & $0,66 \%$ & $0,88 \%$ & $1,11 \%$ & $1,35 \%$ \\
\hline ESP & $0,21 \%$ & $0,43 \%$ & $0,66 \%$ & $0,88 \%$ & 1,11\% & $1,35 \%$ \\
\hline EST & $0,21 \%$ & $0,43 \%$ & $0,66 \%$ & $0,88 \%$ & $1,11 \%$ & $1,35 \%$ \\
\hline FIN & $0,21 \%$ & $0,43 \%$ & $0,66 \%$ & $0,88 \%$ & 1,11 \% & $1,35 \%$ \\
\hline FRA & $0,21 \%$ & $0,43 \%$ & $0,66 \%$ & $0,88 \%$ & $1,11 \%$ & $1,35 \%$ \\
\hline GBR & $0,21 \%$ & $0,43 \%$ & $0,66 \%$ & $0,88 \%$ & 1,11\% & $1,35 \%$ \\
\hline GRC & $0,21 \%$ & $0,43 \%$ & $0,66 \%$ & $0,88 \%$ & $1,11 \%$ & $1,35 \%$ \\
\hline HRV & $0,21 \%$ & $0,43 \%$ & $0,66 \%$ & $0,88 \%$ & $1,11 \%$ & $1,35 \%$ \\
\hline HUN & $0,21 \%$ & $0,43 \%$ & $0,66 \%$ & $0,88 \%$ & $1,11 \%$ & $1,35 \%$ \\
\hline IDN & $0,14 \%$ & $0,27 \%$ & $0,42 \%$ & $0,56 \%$ & $0,71 \%$ & $0,86 \%$ \\
\hline IND & $0,08 \%$ & $0,15 \%$ & $0,24 \%$ & $0,32 \%$ & $0,41 \%$ & $0,51 \%$ \\
\hline IRL & $0,21 \%$ & $0,43 \%$ & $0,66 \%$ & $0,88 \%$ & $1,11 \%$ & $1,35 \%$ \\
\hline ITA & $0,21 \%$ & $0,43 \%$ & $0,66 \%$ & $0,88 \%$ & $1,11 \%$ & $1,35 \%$ \\
\hline JPN & $0,10 \%$ & 0,19 \% & $0,29 \%$ & $0,39 \%$ & $0,50 \%$ & $0,60 \%$ \\
\hline KOR & $0,18 \%$ & $0,37 \%$ & $0,56 \%$ & $0,76 \%$ & $0,96 \%$ & $1,16 \%$ \\
\hline LTU & $0,21 \%$ & $0,43 \%$ & $0,66 \%$ & $0,88 \%$ & $1,11 \%$ & $1,35 \%$ \\
\hline LUX & $0,21 \%$ & $0,43 \%$ & $0,66 \%$ & $0,88 \%$ & $1,11 \%$ & $1,35 \%$ \\
\hline LVA & $0,21 \%$ & $0,43 \%$ & $0,66 \%$ & $0,88 \%$ & 1,11 \% & $1,35 \%$ \\
\hline MEX & $0,15 \%$ & $0,29 \%$ & $0,44 \%$ & $0,59 \%$ & $0,74 \%$ & $0,90 \%$ \\
\hline MLT & $0,21 \%$ & $0,43 \%$ & $0,66 \%$ & $0,88 \%$ & $1,11 \%$ & $1,35 \%$ \\
\hline NLD & $0,21 \%$ & $0,43 \%$ & $0,66 \%$ & $0,88 \%$ & $1,11 \%$ & $1,35 \%$ \\
\hline NOR & $0,22 \%$ & $0,44 \%$ & $0,66 \%$ & $0,89 \%$ & 1,12 \% & 1,34 \% \\
\hline POL & $0,21 \%$ & $0,43 \%$ & $0,66 \%$ & $0,88 \%$ & $1,11 \%$ & $1,35 \%$ \\
\hline PRT & $0,21 \%$ & $0,43 \%$ & $0,66 \%$ & $0,88 \%$ & $1,11 \%$ & $1,35 \%$ \\
\hline ROU & $0,21 \%$ & $0,43 \%$ & $0,66 \%$ & $0,88 \%$ & $1,11 \%$ & $1,35 \%$ \\
\hline RUS & $0,20 \%$ & $0,40 \%$ & $0,60 \%$ & $0,81 \%$ & 1,01 \% & $1,22 \%$ \\
\hline SVK & $0,21 \%$ & $0,43 \%$ & $0,66 \%$ & $0,88 \%$ & $1,11 \%$ & $1,35 \%$ \\
\hline SVN & $0,21 \%$ & $0,43 \%$ & $0,66 \%$ & $0,88 \%$ & $1,11 \%$ & $1,35 \%$ \\
\hline SWE & $0,21 \%$ & $0,43 \%$ & $0,66 \%$ & $0,88 \%$ & $1,11 \%$ & $1,35 \%$ \\
\hline TUR & $0,17 \%$ & $0,35 \%$ & $0,52 \%$ & $0,70 \%$ & $0,89 \%$ & $1,07 \%$ \\
\hline TWN & $0,28 \%$ & $0,57 \%$ & $0,86 \%$ & $1,16 \%$ & $1,46 \%$ & $1,76 \%$ \\
\hline USA & $0,07 \%$ & $0,14 \%$ & $0,21 \%$ & $0,28 \%$ & $0,36 \%$ & $0,43 \%$ \\
\hline ROW & $0,21 \%$ & $0,43 \%$ & $0,65 \%$ & $0,87 \%$ & $1,10 \%$ & $1,34 \%$ \\
\hline
\end{tabular}


Table A8: Real income effects of alternative scenarios

\begin{tabular}{|c|c|c|c|c|c|c|c|c|}
\hline & \multicolumn{2}{|c|}{ Aichele et al. } & \multicolumn{2}{|c|}{ Francois et al. } & \multicolumn{2}{|c|}{ Fontagné et al. } & \multicolumn{2}{|c|}{ Fontagné averages } \\
\hline & immobile & mobile & immobile & mobile & immobile & mobile & immobile & mobile \\
\hline AUS & $-0,08 \%$ & $-0,08 \%$ & $0,00 \%$ & $0,00 \%$ & $0,00 \%$ & $0,00 \%$ & $0,00 \%$ & $0,00 \%$ \\
\hline AUT & $0,78 \%$ & $1,28 \%$ & $0,05 \%$ & $0,09 \%$ & $0,06 \%$ & $0,14 \%$ & $0,11 \%$ & $0,20 \%$ \\
\hline BEL & $1,45 \%$ & $1,28 \%$ & $0,16 \%$ & $0,09 \%$ & $0,29 \%$ & $0,14 \%$ & $0,44 \%$ & $0,20 \%$ \\
\hline BGR & $0,83 \%$ & $1,28 \%$ & $0,03 \%$ & $0,09 \%$ & $0,07 \%$ & $0,14 \%$ & $0,07 \%$ & $0,20 \%$ \\
\hline BRA & $-0,02 \%$ & $-0,02 \%$ & $0,00 \%$ & $0,00 \%$ & $0,00 \%$ & $0,00 \%$ & $0,00 \%$ & $0,00 \%$ \\
\hline CAN & $-0,48 \%$ & $-0,49 \%$ & $0,01 \%$ & $0,01 \%$ & $0,01 \%$ & $0,01 \%$ & $0,01 \%$ & $0,01 \%$ \\
\hline $\mathrm{CHE}$ & $-0,12 \%$ & $-0,12 \%$ & $-0,01 \%$ & $-0,01 \%$ & $-0,02 \%$ & $-0,01 \%$ & $-0,03 \%$ & $-0,02 \%$ \\
\hline $\mathrm{CHN}$ & $-0,08 \%$ & $-0,08 \%$ & $0,00 \%$ & $0,00 \%$ & $-0,01 \%$ & $-0,01 \%$ & $-0,01 \%$ & $-0,01 \%$ \\
\hline CYP & $0,27 \%$ & $1,28 \%$ & $0,02 \%$ & $0,09 \%$ & $0,07 \%$ & $0,14 \%$ & $0,07 \%$ & $0,20 \%$ \\
\hline CZE & $0,97 \%$ & $1,28 \%$ & $0,05 \%$ & $0,09 \%$ & $0,03 \%$ & $0,14 \%$ & $0,09 \%$ & $0,20 \%$ \\
\hline DEU & $1,03 \%$ & $1,28 \%$ & $0,10 \%$ & $0,09 \%$ & $0,13 \%$ & $0,14 \%$ & $0,20 \%$ & $0,20 \%$ \\
\hline DNK & $0,18 \%$ & $1,28 \%$ & $0,06 \%$ & $0,09 \%$ & $0,08 \%$ & $0,14 \%$ & $0,15 \%$ & $0,20 \%$ \\
\hline ESP & $1,17 \%$ & $1,28 \%$ & $0,03 \%$ & $0,09 \%$ & $0,05 \%$ & $0,14 \%$ & $0,08 \%$ & $0,20 \%$ \\
\hline EST & $0,66 \%$ & $1,28 \%$ & $0,05 \%$ & $0,09 \%$ & $0,07 \%$ & $0,14 \%$ & $0,11 \%$ & $0,20 \%$ \\
\hline FIN & $1,37 \%$ & $1,28 \%$ & $0,07 \%$ & $0,09 \%$ & $0,12 \%$ & $0,14 \%$ & $0,17 \%$ & $0,20 \%$ \\
\hline FRA & $0,76 \%$ & $1,28 \%$ & $0,07 \%$ & $0,09 \%$ & $0,12 \%$ & $0,14 \%$ & $0,18 \%$ & $0,20 \%$ \\
\hline GBR & $2,30 \%$ & $1,28 \%$ & $0,12 \%$ & $0,09 \%$ & $0,22 \%$ & $0,14 \%$ & $0,28 \%$ & $0,20 \%$ \\
\hline GRC & $0,48 \%$ & $1,28 \%$ & $0,02 \%$ & $0,09 \%$ & $0,03 \%$ & $0,14 \%$ & $0,06 \%$ & $0,20 \%$ \\
\hline HRV & $2,86 \%$ & $1,28 \%$ & $0,02 \%$ & $0,09 \%$ & $0,07 \%$ & $0,14 \%$ & $0,08 \%$ & $0,20 \%$ \\
\hline HUN & $1,58 \%$ & $1,28 \%$ & $0,07 \%$ & $0,09 \%$ & $0,11 \%$ & $0,14 \%$ & $0,21 \%$ & $0,20 \%$ \\
\hline IDN & $-0,05 \%$ & $-0,05 \%$ & $0,00 \%$ & $0,00 \%$ & $0,00 \%$ & $0,00 \%$ & $0,00 \%$ & $0,00 \%$ \\
\hline IND & $0,01 \%$ & $0,01 \%$ & $0,00 \%$ & $0,00 \%$ & $0,00 \%$ & $0,00 \%$ & $0,00 \%$ & $0,00 \%$ \\
\hline IRL & $4,59 \%$ & $1,28 \%$ & $0,66 \%$ & $0,09 \%$ & $1,40 \%$ & $0,14 \%$ & $1,86 \%$ & $0,20 \%$ \\
\hline ITA & $0,91 \%$ & $1,28 \%$ & $0,05 \%$ & $0,09 \%$ & $0,06 \%$ & $0,14 \%$ & $0,10 \%$ & $0,20 \%$ \\
\hline JPN & $0,02 \%$ & $0,02 \%$ & $0,00 \%$ & $0,00 \%$ & $0,00 \%$ & $0,00 \%$ & $0,00 \%$ & $0,00 \%$ \\
\hline KOR & $-0,10 \%$ & $-0,10 \%$ & $-0,01 \%$ & $-0,01 \%$ & $-0,01 \%$ & $-0,01 \%$ & $-0,02 \%$ & $-0,02 \%$ \\
\hline LTU & $0,79 \%$ & $1,28 \%$ & $0,05 \%$ & $0,09 \%$ & $0,02 \%$ & $0,14 \%$ & $0,08 \%$ & $0,20 \%$ \\
\hline LUX & $1,58 \%$ & $1,28 \%$ & $0,38 \%$ & $0,09 \%$ & $0,81 \%$ & $0,14 \%$ & $1,04 \%$ & $0,20 \%$ \\
\hline LVA & $0,93 \%$ & $1,28 \%$ & $0,03 \%$ & $0,09 \%$ & $0,04 \%$ & $0,14 \%$ & $0,06 \%$ & $0,20 \%$ \\
\hline MEX & $-0,31 \%$ & $-0,31 \%$ & $0,00 \%$ & $0,00 \%$ & $0,00 \%$ & $0,00 \%$ & $0,00 \%$ & $0,00 \%$ \\
\hline MLT & $1,22 \%$ & $1,28 \%$ & $0,11 \%$ & $0,09 \%$ & $0,24 \%$ & $0,14 \%$ & $0,29 \%$ & $0,20 \%$ \\
\hline NLD & $2,11 \%$ & $1,28 \%$ & $0,13 \%$ & $0,09 \%$ & $0,18 \%$ & $0,14 \%$ & $0,37 \%$ & $0,20 \%$ \\
\hline NOR & $-1,64 \%$ & $-1,65 \%$ & $0,01 \%$ & $0,01 \%$ & $-0,03 \%$ & $-0,03 \%$ & $-0,03 \%$ & $-0,04 \%$ \\
\hline POL & $0,95 \%$ & $1,28 \%$ & $0,04 \%$ & $0,09 \%$ & $0,06 \%$ & $0,14 \%$ & $0,08 \%$ & $0,20 \%$ \\
\hline PRT & $0,86 \%$ & $1,28 \%$ & $0,02 \%$ & $0,09 \%$ & $0,06 \%$ & $0,14 \%$ & $0,07 \%$ & $0,20 \%$ \\
\hline ROU & $1,28 \%$ & $1,28 \%$ & $0,03 \%$ & $0,09 \%$ & $0,07 \%$ & $0,14 \%$ & $0,08 \%$ & $0,20 \%$ \\
\hline RUS & $-0,45 \%$ & $-0,45 \%$ & $0,00 \%$ & $0,00 \%$ & $-0,01 \%$ & $-0,01 \%$ & $-0,01 \%$ & $-0,02 \%$ \\
\hline SVK & $1,77 \%$ & $1,28 \%$ & $0,02 \%$ & $0,09 \%$ & $0,07 \%$ & $0,14 \%$ & $0,09 \%$ & $0,20 \%$ \\
\hline SVN & $0,64 \%$ & $1,28 \%$ & $0,03 \%$ & $0,09 \%$ & $0,01 \%$ & $0,14 \%$ & $0,04 \%$ & $0,20 \%$ \\
\hline SWE & $0,93 \%$ & $1,28 \%$ & $0,06 \%$ & $0,09 \%$ & $0,10 \%$ & $0,14 \%$ & $0,16 \%$ & $0,20 \%$ \\
\hline TUR & $-0,01 \%$ & $-0,01 \%$ & $0,00 \%$ & $0,00 \%$ & $0,00 \%$ & $0,00 \%$ & $0,00 \%$ & $0,00 \%$ \\
\hline TWN & $-0,14 \%$ & $-0,15 \%$ & $-0,02 \%$ & $-0,02 \%$ & $-0,02 \%$ & $-0,02 \%$ & $-0,03 \%$ & $-0,03 \%$ \\
\hline USA & $0,98 \%$ & $0,99 \%$ & $0,11 \%$ & $0,12 \%$ & $0,13 \%$ & $0,14 \%$ & $0,23 \%$ & $0,23 \%$ \\
\hline ROW & $-0,19 \%$ & $-0,18 \%$ & $0,00 \%$ & $0,01 \%$ & $0,01 \%$ & $0,01 \%$ & $0,01 \%$ & $0,01 \%$ \\
\hline
\end{tabular}

The last two columns rely on the average barriers for agriculture, manufacturing and services directly reported in Fontagné et al. (2013) instead of the disaggregated values (columns 5 and 6) which we obtain from following their described method as closely as possible. 
Table A9: Real income effects and spillovers (maximal liberalization)

\begin{tabular}{|c|c|c|c|c|c|c|}
\hline \multirow[b]{2}{*}{ Spillovers: } & \multicolumn{3}{|c|}{ immobile } & \multicolumn{3}{|c|}{ mobile } \\
\hline & no & direct & \& indirect & no & direct & \& indirect \\
\hline AUS & $0,00 \%$ & $0,05 \%$ & $0,32 \%$ & $0,00 \%$ & $0,05 \%$ & $0,32 \%$ \\
\hline AUT & $0,17 \%$ & $0,28 \%$ & $0,34 \%$ & $0,32 \%$ & $0,46 \%$ & $0,53 \%$ \\
\hline BEL & $0,70 \%$ & $0,91 \%$ & $1,03 \%$ & $0,32 \%$ & $0,46 \%$ & $0,53 \%$ \\
\hline BGR & $0,12 \%$ & $0,45 \%$ & $0,57 \%$ & $0,32 \%$ & $0,46 \%$ & $0,53 \%$ \\
\hline BRA & $0,00 \%$ & $0,03 \%$ & $0,17 \%$ & $0,00 \%$ & $0,04 \%$ & $0,17 \%$ \\
\hline CAN & $0,02 \%$ & $0,29 \%$ & $0,57 \%$ & $0,02 \%$ & $0,29 \%$ & $0,57 \%$ \\
\hline $\mathrm{CHE}$ & $-0,05 \%$ & $0,28 \%$ & $0,60 \%$ & $-0,03 \%$ & $0,29 \%$ & $0,62 \%$ \\
\hline $\mathrm{CHN}$ & $-0,02 \%$ & $0,03 \%$ & $0,12 \%$ & $-0,02 \%$ & $0,03 \%$ & $0,12 \%$ \\
\hline CYP & $0,10 \%$ & $0,40 \%$ & $0,50 \%$ & $0,32 \%$ & $0,46 \%$ & $0,53 \%$ \\
\hline CZE & $0,15 \%$ & $0,23 \%$ & $0,31 \%$ & $0,32 \%$ & $0,46 \%$ & $0,53 \%$ \\
\hline DEU & $0,32 \%$ & $0,43 \%$ & $0,51 \%$ & $0,32 \%$ & $0,46 \%$ & $0,53 \%$ \\
\hline DNK & $0,24 \%$ & $0,36 \%$ & $0,45 \%$ & $0,32 \%$ & $0,46 \%$ & $0,53 \%$ \\
\hline ESP & $0,13 \%$ & $0,28 \%$ & $0,34 \%$ & $0,32 \%$ & $0,46 \%$ & $0,53 \%$ \\
\hline EST & $0,18 \%$ & $0,45 \%$ & $0,56 \%$ & $0,32 \%$ & $0,46 \%$ & $0,53 \%$ \\
\hline FIN & $0,28 \%$ & $0,41 \%$ & $0,46 \%$ & $0,32 \%$ & $0,46 \%$ & $0,53 \%$ \\
\hline FRA & $0,26 \%$ & $0,39 \%$ & $0,44 \%$ & $0,32 \%$ & $0,46 \%$ & $0,53 \%$ \\
\hline GBR & $0,43 \%$ & $0,57 \%$ & $0,64 \%$ & $0,32 \%$ & $0,46 \%$ & $0,53 \%$ \\
\hline GRC & $0,11 \%$ & $0,33 \%$ & $0,38 \%$ & $0,32 \%$ & $0,46 \%$ & $0,53 \%$ \\
\hline HRV & $0,14 \%$ & $0,36 \%$ & $0,48 \%$ & $0,32 \%$ & $0,46 \%$ & $0,53 \%$ \\
\hline HUN & 0,33 \% & $0,49 \%$ & $0,59 \%$ & $0,32 \%$ & $0,46 \%$ & $0,53 \%$ \\
\hline IDN & $0,00 \%$ & $0,02 \%$ & $0,29 \%$ & $0,00 \%$ & $0,02 \%$ & $0,29 \%$ \\
\hline IND & $0,00 \%$ & $0,02 \%$ & $0,16 \%$ & $0,00 \%$ & $0,02 \%$ & $0,16 \%$ \\
\hline IRL & $3,03 \%$ & $3,40 \%$ & $3,66 \%$ & $0,32 \%$ & $0,46 \%$ & $0,53 \%$ \\
\hline ITA & $0,16 \%$ & $0,25 \%$ & $0,29 \%$ & $0,32 \%$ & $0,46 \%$ & $0,53 \%$ \\
\hline JPN & $0,00 \%$ & $0,01 \%$ & $0,20 \%$ & $0,00 \%$ & 0,01\% & $0,20 \%$ \\
\hline KOR & $-0,03 \%$ & $0,04 \%$ & 0,39 \% & $-0,04 \%$ & $0,04 \%$ & $0,38 \%$ \\
\hline LTU & $0,13 \%$ & $0,47 \%$ & $0,60 \%$ & $0,32 \%$ & $0,46 \%$ & $0,53 \%$ \\
\hline LUX & $1,85 \%$ & $2,51 \%$ & $2,97 \%$ & $0,32 \%$ & $0,46 \%$ & $0,53 \%$ \\
\hline LVA & $0,09 \%$ & $0,35 \%$ & $0,43 \%$ & $0,32 \%$ & $0,46 \%$ & $0,53 \%$ \\
\hline MEX & $0,00 \%$ & $0,17 \%$ & $0,38 \%$ & $0,00 \%$ & $0,18 \%$ & $0,38 \%$ \\
\hline MLT & $0,46 \%$ & $0,85 \%$ & $1,01 \%$ & $0,32 \%$ & $0,46 \%$ & $0,53 \%$ \\
\hline NLD & $0,55 \%$ & $0,66 \%$ & $0,81 \%$ & $0,32 \%$ & $0,46 \%$ & $0,53 \%$ \\
\hline NOR & $-0,06 \%$ & $0,26 \%$ & $0,57 \%$ & $-0,06 \%$ & $0,26 \%$ & $0,56 \%$ \\
\hline POL & $0,12 \%$ & $0,23 \%$ & $0,30 \%$ & $0,32 \%$ & $0,46 \%$ & $0,53 \%$ \\
\hline PRT & $0,12 \%$ & $0,30 \%$ & $0,35 \%$ & $0,32 \%$ & $0,46 \%$ & $0,53 \%$ \\
\hline ROU & $0,13 \%$ & $0,29 \%$ & $0,35 \%$ & $0,32 \%$ & $0,46 \%$ & $0,53 \%$ \\
\hline RUS & $-0,03 \%$ & $0,11 \%$ & $0,44 \%$ & $-0,03 \%$ & $0,10 \%$ & $0,44 \%$ \\
\hline SVK & $0,15 \%$ & $0,37 \%$ & $0,47 \%$ & $0,32 \%$ & $0,46 \%$ & $0,53 \%$ \\
\hline SVN & $0,08 \%$ & $0,26 \%$ & $0,36 \%$ & $0,32 \%$ & $0,46 \%$ & $0,53 \%$ \\
\hline SWE & $0,26 \%$ & $0,39 \%$ & $0,47 \%$ & $0,32 \%$ & $0,46 \%$ & $0,53 \%$ \\
\hline TUR & $0,00 \%$ & $0,14 \%$ & $0,42 \%$ & $0,00 \%$ & $0,14 \%$ & $0,42 \%$ \\
\hline TWN & $-0,05 \%$ & $0,06 \%$ & $0,59 \%$ & $-0,05 \%$ & $0,05 \%$ & $0,58 \%$ \\
\hline USA & $0,37 \%$ & $0,49 \%$ & $0,54 \%$ & $0,38 \%$ & $0,50 \%$ & $0,54 \%$ \\
\hline ROW & $0,01 \%$ & $0,14 \%$ & $0,50 \%$ & $0,03 \%$ & $0,15 \%$ & $0,51 \%$ \\
\hline
\end{tabular}

Real income effects for maximal liberalization with and without population mobility and with no spillovers, only $20 \%$ direct spillovers or $20 \%$ direct and $10 \%$ indirect spillovers. 
Table A10: Real income effects and service trade (maximal liberalization)

\begin{tabular}{|c|c|c|c|c|c|c|}
\hline & \multicolumn{3}{|c|}{ immobile } & \multicolumn{3}{|c|}{ mobile } \\
\hline & $\begin{array}{c}\text { full } \\
\text { liberalization }\end{array}$ & $\begin{array}{c}\text { no service } \\
\text { liberalization }\end{array}$ & $\begin{array}{c}\text { no finance } \\
\text { liberalization }\end{array}$ & $\begin{array}{c}\text { full } \\
\text { liberalization }\end{array}$ & $\begin{array}{c}\text { no service } \\
\text { liberalization }\end{array}$ & $\begin{array}{c}\text { no finance } \\
\text { liberalization }\end{array}$ \\
\hline AUS & $0,00 \%$ & $0,00 \%$ & $0,00 \%$ & $0,00 \%$ & $0,00 \%$ & $0,00 \%$ \\
\hline AUT & $0,17 \%$ & $0,11 \%$ & $0,17 \%$ & $0,32 \%$ & $0,17 \%$ & $0,31 \%$ \\
\hline BEL & $0,70 \%$ & $0,34 \%$ & $0,69 \%$ & $0,32 \%$ & $0,17 \%$ & $0,31 \%$ \\
\hline BGR & $0,12 \%$ & $0,05 \%$ & $0,12 \%$ & 0,32 \% & $0,17 \%$ & $0,31 \%$ \\
\hline BRA & $0,00 \%$ & $0,00 \%$ & $0,00 \%$ & $0,00 \%$ & $0,00 \%$ & $0,00 \%$ \\
\hline CAN & $0,02 \%$ & $0,01 \%$ & $0,02 \%$ & $0,02 \%$ & $0,01 \%$ & $0,02 \%$ \\
\hline $\mathrm{CHE}$ & $-0,05 \%$ & $-0,03 \%$ & $-0,03 \%$ & $-0,03 \%$ & $-0,03 \%$ & $-0,02 \%$ \\
\hline $\mathrm{CHN}$ & $-0,02 \%$ & $-0,01 \%$ & $-0,02 \%$ & $-0,02 \%$ & $-0,01 \%$ & $-0,02 \%$ \\
\hline CYP & $0,10 \%$ & $0,04 \%$ & $0,08 \%$ & $0,32 \%$ & $0,17 \%$ & $0,31 \%$ \\
\hline CZE & $0,15 \%$ & $0,10 \%$ & $0,15 \%$ & $0,32 \%$ & $0,17 \%$ & $0,31 \%$ \\
\hline DEU & $0,32 \%$ & $0,22 \%$ & $0,32 \%$ & $0,32 \%$ & $0,17 \%$ & $0,31 \%$ \\
\hline DNK & $0,24 \%$ & $0,08 \%$ & $0,24 \%$ & $0,32 \%$ & $0,17 \%$ & $0,31 \%$ \\
\hline ESP & $0,13 \%$ & $0,11 \%$ & $0,13 \%$ & $0,32 \%$ & $0,17 \%$ & $0,31 \%$ \\
\hline EST & $0,18 \%$ & $0,13 \%$ & $0,18 \%$ & $0,32 \%$ & $0,17 \%$ & $0,31 \%$ \\
\hline FIN & $0,28 \%$ & $0,14 \%$ & $0,28 \%$ & $0,32 \%$ & $0,17 \%$ & $0,31 \%$ \\
\hline FRA & $0,26 \%$ & $0,14 \%$ & $0,26 \%$ & $0,32 \%$ & $0,17 \%$ & $0,31 \%$ \\
\hline GBR & $0,43 \%$ & $0,27 \%$ & $0,41 \%$ & $0,32 \%$ & $0,17 \%$ & $0,31 \%$ \\
\hline GRC & $0,11 \%$ & $0,03 \%$ & $0,10 \%$ & $0,32 \%$ & $0,17 \%$ & $0,31 \%$ \\
\hline HRV & $0,14 \%$ & $0,11 \%$ & $0,13 \%$ & $0,32 \%$ & $0,17 \%$ & $0,31 \%$ \\
\hline HUN & $0,33 \%$ & $0,17 \%$ & $0,33 \%$ & $0,32 \%$ & $0,17 \%$ & $0,31 \%$ \\
\hline IDN & $0,00 \%$ & $0,00 \%$ & $0,00 \%$ & $0,00 \%$ & $0,00 \%$ & $0,00 \%$ \\
\hline IND & $0,00 \%$ & $0,00 \%$ & $0,00 \%$ & $0,00 \%$ & $0,00 \%$ & $0,00 \%$ \\
\hline IRL & $3,03 \%$ & $0,52 \%$ & $2,57 \%$ & $0,32 \%$ & $0,17 \%$ & $0,31 \%$ \\
\hline ITA & $0,16 \%$ & $0,11 \%$ & $0,16 \%$ & $0,32 \%$ & $0,17 \%$ & $0,31 \%$ \\
\hline JPN & $0,00 \%$ & $0,00 \%$ & $0,00 \%$ & $0,00 \%$ & $0,00 \%$ & $0,00 \%$ \\
\hline KOR & $-0,03 \%$ & $-0,02 \%$ & $-0,03 \%$ & $-0,04 \%$ & $-0,03 \%$ & $-0,04 \%$ \\
\hline LTU & $0,13 \%$ & $0,13 \%$ & $0,13 \%$ & $0,32 \%$ & $0,17 \%$ & $0,31 \%$ \\
\hline LUX & $1,85 \%$ & $0,05 \%$ & $0,32 \%$ & $0,32 \%$ & $0,17 \%$ & $0,31 \%$ \\
\hline LVA & $0,09 \%$ & $0,06 \%$ & $0,09 \%$ & $0,32 \%$ & $0,17 \%$ & $0,31 \%$ \\
\hline MEX & $0,00 \%$ & $-0,01 \%$ & $0,00 \%$ & $0,00 \%$ & $-0,01 \%$ & $0,00 \%$ \\
\hline MLT & $0,46 \%$ & $0,16 \%$ & $0,27 \%$ & $0,32 \%$ & $0,17 \%$ & $0,31 \%$ \\
\hline NLD & $0,55 \%$ & $0,22 \%$ & $0,54 \%$ & $0,32 \%$ & $0,17 \%$ & $0,31 \%$ \\
\hline NOR & $-0,06 \%$ & $-0,07 \%$ & $-0,06 \%$ & $-0,06 \%$ & $-0,07 \%$ & $-0,06 \%$ \\
\hline POL & $0,12 \%$ & $0,07 \%$ & $0,12 \%$ & $0,32 \%$ & $0,17 \%$ & $0,31 \%$ \\
\hline PRT & $0,12 \%$ & $0,06 \%$ & $0,11 \%$ & $0,32 \%$ & $0,17 \%$ & $0,31 \%$ \\
\hline ROU & $0,13 \%$ & $0,09 \%$ & $0,13 \%$ & $0,32 \%$ & $0,17 \%$ & $0,31 \%$ \\
\hline RUS & $-0,03 \%$ & $-0,03 \%$ & $-0,02 \%$ & $-0,03 \%$ & $-0,03 \%$ & $-0,03 \%$ \\
\hline SVK & $0,15 \%$ & $0,16 \%$ & $0,15 \%$ & $0,32 \%$ & $0,17 \%$ & $0,31 \%$ \\
\hline SVN & $0,08 \%$ & $0,06 \%$ & $0,08 \%$ & $0,32 \%$ & $0,17 \%$ & $0,31 \%$ \\
\hline SWE & $0,26 \%$ & $0,10 \%$ & $0,26 \%$ & $0,32 \%$ & $0,17 \%$ & $0,31 \%$ \\
\hline TUR & $0,00 \%$ & $0,00 \%$ & $0,00 \%$ & $0,00 \%$ & $0,00 \%$ & $0,00 \%$ \\
\hline TWN & $-0,05 \%$ & $-0,03 \%$ & $-0,05 \%$ & $-0,05 \%$ & $-0,03 \%$ & $-0,05 \%$ \\
\hline USA & $0,37 \%$ & $0,23 \%$ & $0,36 \%$ & $0,38 \%$ & $0,24 \%$ & $0,36 \%$ \\
\hline ROW & $0,01 \%$ & $-0,01 \%$ & $0,01 \%$ & $0,03 \%$ & $0,00 \%$ & $0,02 \%$ \\
\hline
\end{tabular}

Real income effects for maximal liberalization with and without population mobility and with liberalization across all sectors, all sectors except services (19-29), and all sectors except finance (23). 


\begin{tabular}{lllllll} 
& \multicolumn{2}{c}{$\begin{array}{c}\text { maximal } \\
\text { liberalization }\end{array}$} & \multicolumn{2}{c}{$\begin{array}{c}\text { maximal liberalization } \\
\text { (no service liberalization) }\end{array}$} & $\begin{array}{c}\text { Francois et al. (2013) } \\
\text { scenario }\end{array}$ \\
\cline { 2 - 7 } & immobile & mobile & immobile & mobile & immobile & mobile \\
\hline Minimum & $0.31 \%$ & $0.46 \%$ & $0.24 \%$ & $0.34 \%$ & $0,03 \%$ & $0,03 \%$ \\
Maximum & $0.71 \%$ & $0.46 \%$ & $0.49 \%$ & $0.34 \%$ & $0,04 \%$ & $0,03 \%$ \\
Mean & $0.47 \%$ & $0.46 \%$ & $0.35 \%$ & $0.34 \%$ & $0,03 \%$ & $0,03 \%$ \\
Coeff. of variation & 0.127 & & 0.102 & & 0,748 & \\
\hline
\end{tabular}

Range and mean of real income effects across German counties for different liberalization scenarios with and without population mobility. For all cases with population immobility coefficients of variation are reported in the last row. Full results across all German regions are available in a supplementary appendix. 
Figure A1: Shares of different industries in the region's total production
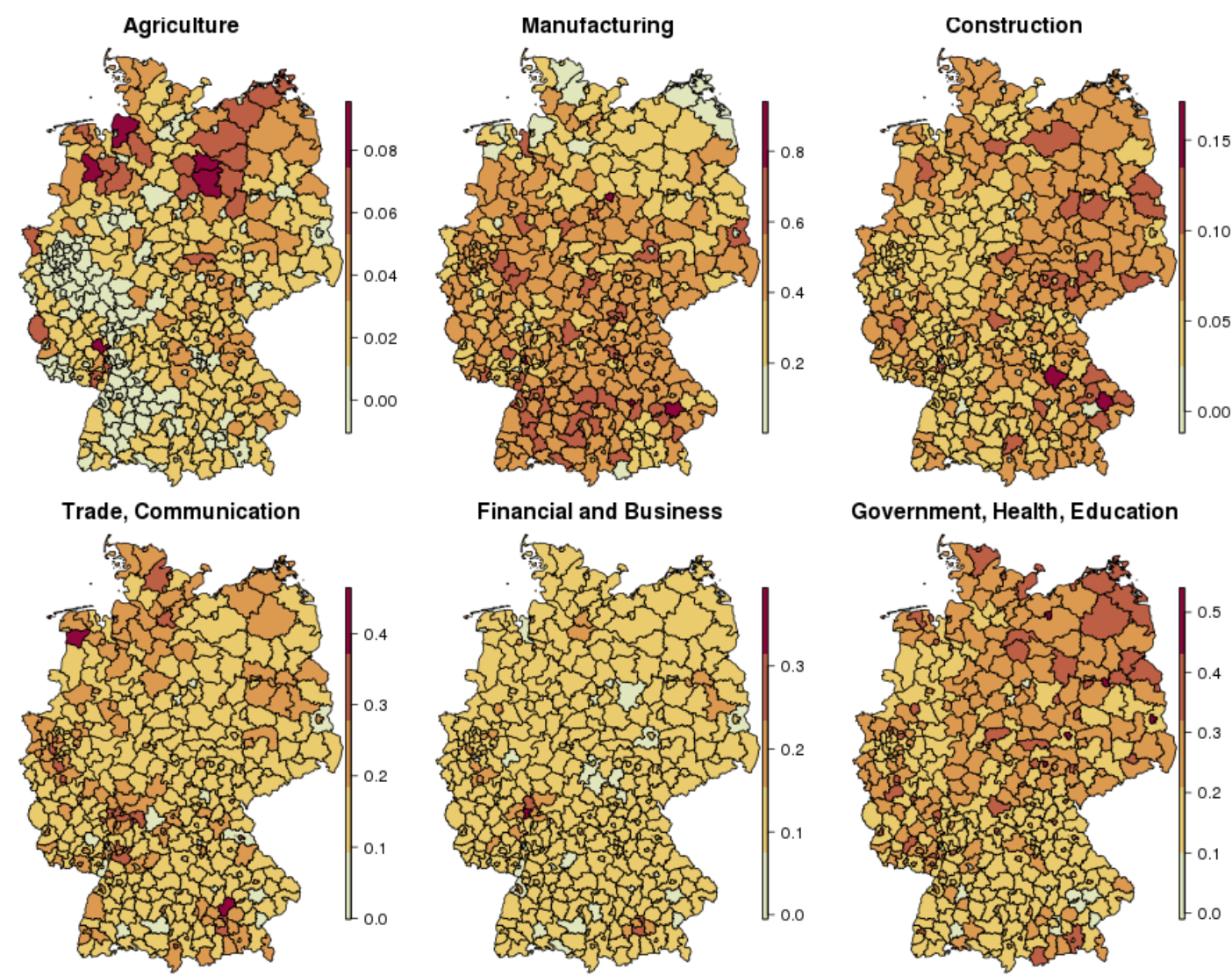

Figure A2: Shares of a regions' industry production in Germany's total industry production
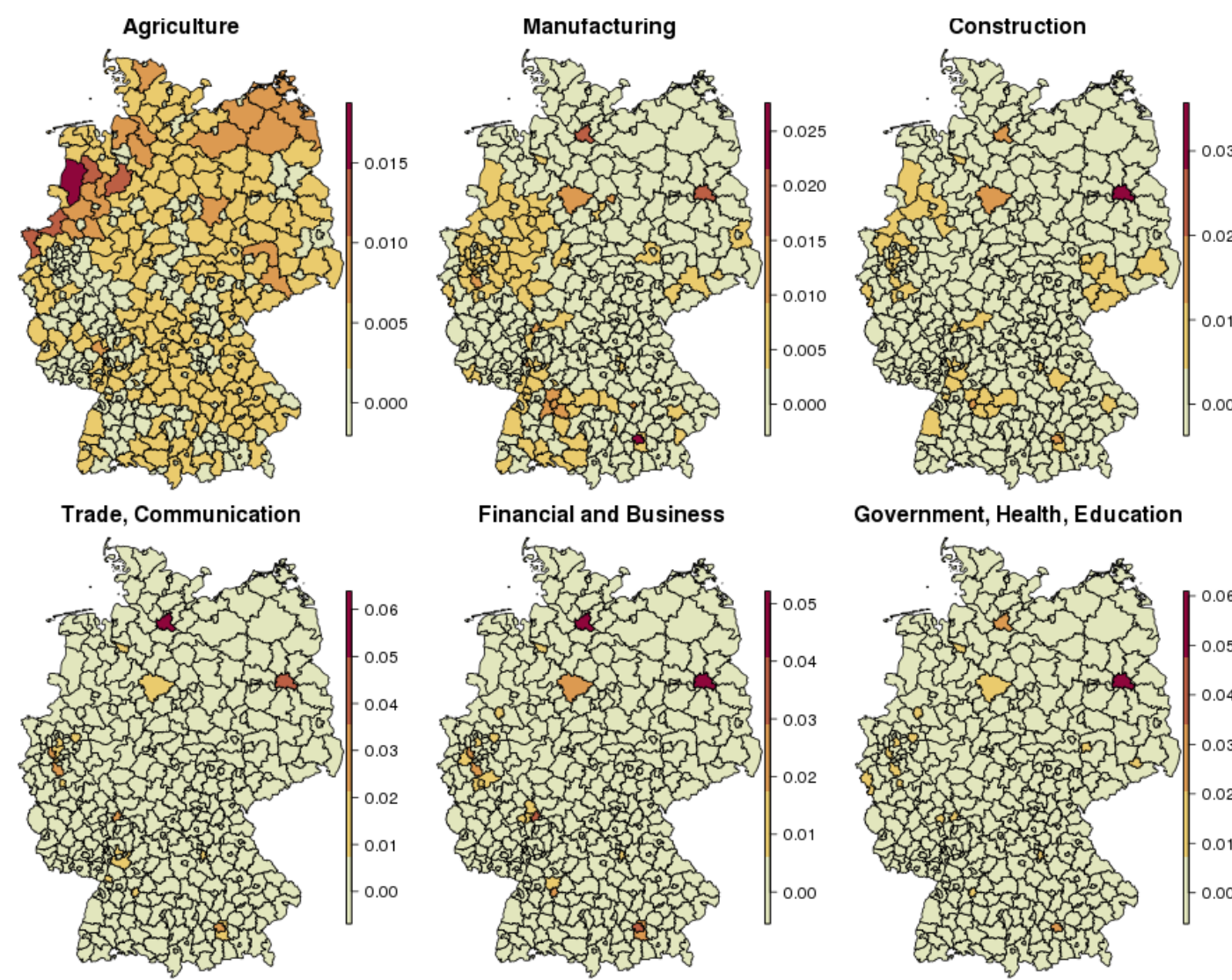

Government, Health, Education

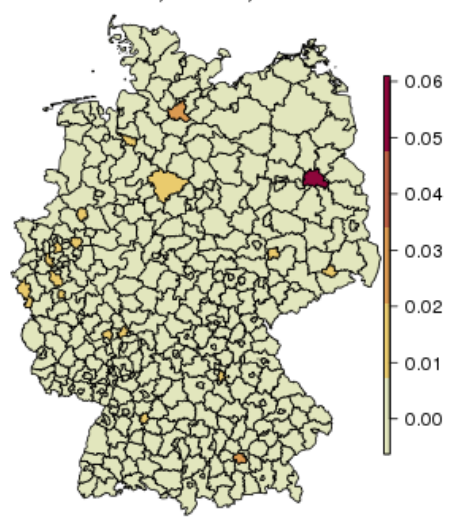


Figure A3: Regional disaggregation, immobile population
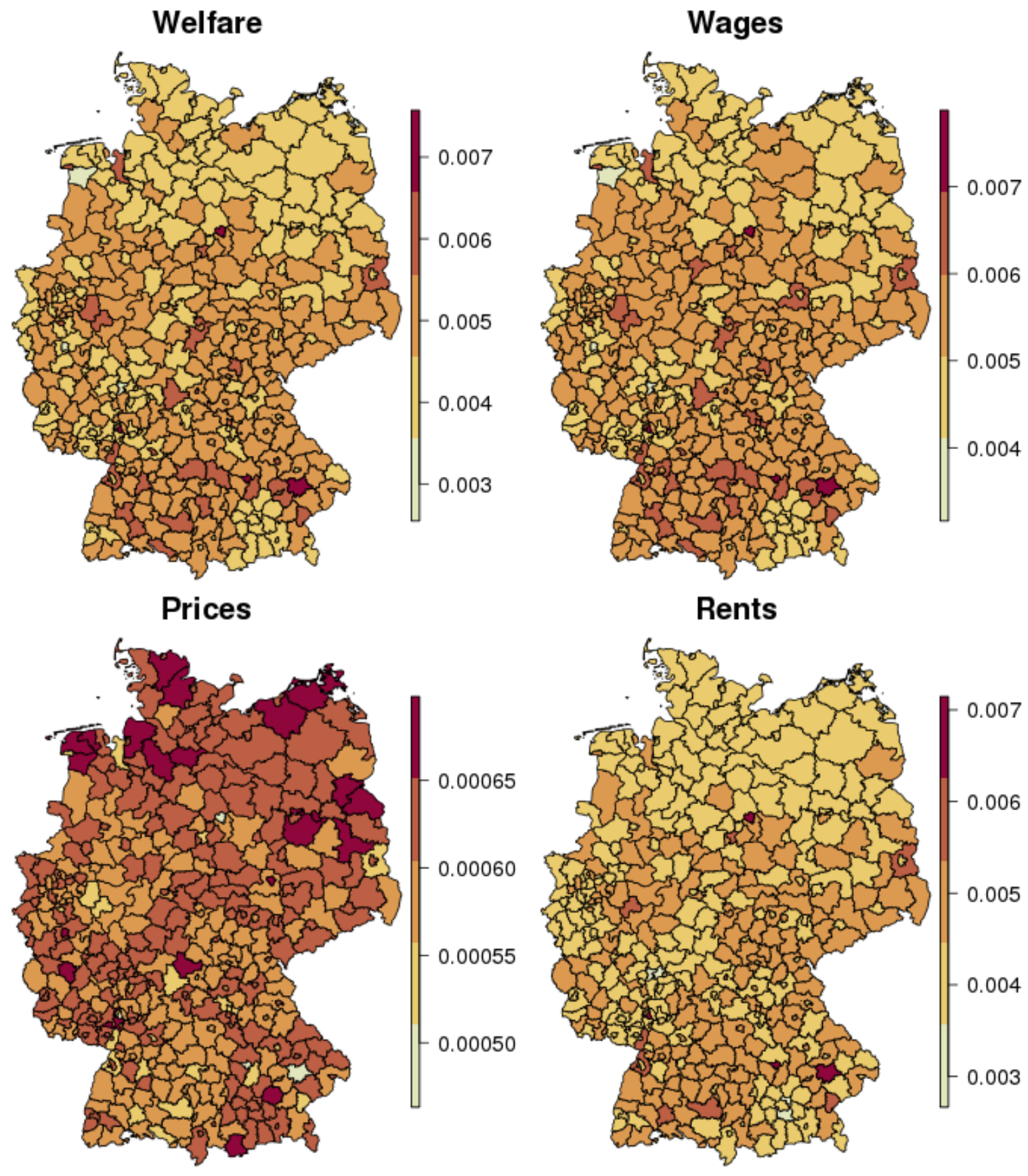


\section{App A1: Derivation of trade shares from the WIOD database}

The raw WIOT-data. For each combination of countries and sectors the WIOT contains an entry $X_{n i, j k}$ for the value of flows from industry $k$ in supplier country $i$ to industry $j$ in destination country $n$, including within country flows $X_{i i, j k}$. It also provides the values of flows from industry $k$ in country $i$ to country $n$ that end up as final consumption by households $X_{n i, C k}$, final consumption by non-profit organizations $X_{n i, P k}$, government spending $X_{n i, G k}$, investments $X_{n i, I k}$ and inventory changes $X_{n i, Q k}$. All entries in these raw data (and in the following) are in value terms at current prices.

Handling of inventory changes. Of course, inventory changes can be negative and sometimes they are significantly large. If we were to calculate final demand by simply summing over consumption, investment, government spending and inventory changes we would end up with a negative final demand in some cases. To reconcile the real world data with our static model that has no room for inventories we follow Costinot and Rodriguez-Claré (2014 Online Appendix) and split the vector of inventory changes into a vector with all positive changes $X_{n i, Q k+}$ and one with all negative changes $X_{n i, Q k-}$ and treat them as follows.

Positive inventory changes are directly included in final demand as are final consumption, government spending and investments, i.e. we treat the build-up of inventory as if it were consumed in the current period. Formally, final demand in country $n$ for goods from industry $k$ in country $i, X_{n i, F k}$, is thus defined as $X_{n i, F k}=X_{n i, C k}+X_{n i, P k}+X_{n i, G k}+X_{n i, I k}+X_{n i, Q k+}$.

Negative inventory changes, in contrast, are treated as if they were produced (and consumed) in the current period. To do this, we can not simply increase our output vector by the respective (absolute) value of inventory changes because the production of the inventory in the last period also required intermediates and, thus, had a larger overall effect. To see how to calculate the necessary changes consider $N$ countries and $K$ sectors in matrix notation. $X$ is the original $(N \cdot K) \times 1$-vector of total outputs, $A$ the $(N \cdot K) \times(N \cdot K)$-matrix of input coefficients, $F$ the $(N \cdot K) \times 1$-vector of final demand including positive inventory changes and $\operatorname{Inv}$ the $(N \cdot K) \times$ 1 -vector of negative inventory changes. Then the total output can be calculated as the sum of intermediate flows, final demand, and inventory changes as $X=A X+F+I n v$. We want to calculate the new level $X_{\text {new }}$ for which the final demand vector is unchanged but inventory changes $I n v$ are set to 0 , i.e. the total output if the negative inventory changes had been produced in the current period. Rearranging terms we get $X_{\text {new }}=(E-A)^{-1} F$ where $E$ is the 
unit matrix. We then obtain the new input output matrix by combining intermediate good flows $A X_{\text {new }}$ and the unchanged final demand vector $F$.

Handling of the real estate sector. For the reasons spelt out in section 3.2, severe data problems make it impossible to base our parameter estimates for the consumption share of land and structures and the cost shares of land and structures in intermediates on the WIOD and complementary databases. Hence, we take these parameter estimates from other sources which we have also characterized in section 3.2. To avoid that the impact of land is considered twice, we eliminate the real estate sector from the WIOT. We do so in the following way which ensures that the final input output matrix is consistent.

First, we eliminate the entry for the real estate sector in final demand and we shift entries of the real estate sector as intermediate into the respective sectoral value added. We also eliminate the entries for all shipments from the other sectors to the real estate sector. The outputs are thus recorded in an $(N \cdot(K-1)) \times 1$-vector $)$, the matrix of input coefficients then becomes a $(N \cdot(K-1)) \times(N \cdot(K-1))$-matrix and the vector of final demands becomes an $(N \cdot(K-1)) \times 1$-vector. At this stage the system is not yet consistent since total use and total output fall apart.

To render the system consistent we calculate the input coefficients of the remaining $N \cdot(K-1)$ sectors by dividing the entries for the shipments of intermediate by the respective sectoral output (the latter are unchanged since the entries for the real estate sector have been shifted to the sectoral value added). We use this to calculate the Leontieff-inverse similarly as before. We now take the final demand as given and recalculate the intermediate demand. The resulting final input-output table is now consistent and used in all calculations.

Derivation of consumption and intermediate goods shares. This final input-output table allows us derive two parameters of the model. Firstly, we calculate the share that industry $k$ has in the consumption of country $n$ by dividing expenditures on industry $k$ by total demand of country $n$ to get $\delta_{n C}^{k}=\sum_{i} X_{n i, F k} / \sum_{k} \sum_{i} X_{n i, F k}$. Similarly, we derive the share that industry $k$ has in the intermediate demand of industry $j$ in country $n$ as $\delta_{n j}^{k}=\sum_{i} X_{n i, j k} / \sum_{k} \sum_{i} X_{n i, j k}$.

Bilateral trade flows and handling of zeros. We also use the adjusted input output matrix to calculate for each industry $k$ the trade flow $X_{\text {nik }}$ between any supplying country $i$ to any destination country $n$. These bilateral trade flows are obtained by summing over all uses of $k$ (intermediate use in all industries and final demand) in its destination country, $X_{n i k}=$ 
$\sum_{j} X_{n i, j k}+X_{n i, F k}$. When looking at the data, several of these bilateral trade flows are zero due to the high level of sectoral and geographical disaggregation. While trade between any two countries in any industry can become arbitrarily small in the Eaton-Kortum model, it would only become zero if trade costs between those two countries were infinitely high. In this case it could no longer hold true that direct trade between those countries would be cheaper than trade via some partner country (with non-infinite trade costs). To avoid these problems, we set all zero trade flows equal to a value of 1 US-Dollar. To put this procedure into perspective, recall that we have aggregated industries such that each country produces output in each industry (cf. section 3.2). Since this output will be in the millions, setting some bilateral trade flows at 1 Dollar has a negligible effect on the other countries' trade shares which we will use.

Country production and spending. Summing over all importing countries $n$ we obtain the value of country $i$ 's total production in industry $k$, i.e. the revenue of firms in industry $k, X_{i k}=$ $\sum_{n} X_{n i k}$. The value of total production (revenue) in country $i$ is then given by summing these across all industries, $R_{i}=\sum_{k} X_{i k}$. Summing across exporting countries $i$ we get country $n$ 's total spending in industry $k, E_{n k}=\sum_{i} X_{n i k}$. Then summing over the spending in each industry gives country $n$ 's total spending $E_{n}=\sum_{k} E_{n k}$.

Bilateral trade shares. We derive the share $\pi_{n i k}$ that country $i$ has in country $n$ 's spending in industry $k$ by dividing industry $k$ flows from $i$ to $n, X_{n i k}$, by country $n$ 's total industry spending $E_{n k}$. Hence, these bilateral trade shares are, $\pi_{n i k}=X_{n i k} / E_{n k}$. 


\section{App A2: Trade Barriers - Robustness check}

In our analysis in the body of the paper we considered a symmetric reduction of the trade barrier parameters $d_{n i k}$ between the US and the European member states by up to $9.97 \%$ of their original value. This threshold reflects an estimate of the tariff equivalents of the pre-existing non-tariff barriers in EU-US-trade which is important because it gives us an upper threshold for the feasible tariff-liberalization corridor (so that we are in the range of non-negative barriers, and hence, so that subsidies are excluded).

There is no fully satisfying way to arrive at an estimate of bilateral trade costs and, hence, there is no hope to arrive at more than a best estimate for the upper threshold for trade cost reductions that we seek. Our estimate is based on a calculation of bilateral trade barriers using the HeadRies index (Head and Mayer 2014). The Head-Ries index provides a standard - if crude - way to recover trade costs from trade data (Head and Mayer 2014). Applied to our model, we would have to use eq. (8) to obtain a simple relation between bilateral trade barriers and trade shares:

$$
\frac{\pi_{n i k} \pi_{i n k}}{\pi_{n n k} \pi_{i i k}}=\left(d_{n i k} d_{i n k}\right)^{-\theta_{k}}
$$

In addition to assuming that there is frictionless trade within locations (which we do throughout our analysis), the Head-Ries index imposes the assumption that bilateral trade costs are fully symmetric, i.e. $d_{n i k}=d_{i n k}$ (which we do not). Then (a1) is immediately inverted and, given an estimate of $\theta_{k}$, (symmetric) bilateral trade costs can be recovered. Of course, this violates our assumption that $d_{n i k}=\kappa_{n i k} v_{n k} \mu_{i k}\left(1+t_{n i k}\right)$ which we used in the body of our paper to estimate the productivity dispersion parameters. There is no way to arrive at an estimate of $d_{\text {nik }}$ given this specification. However, symmetric barriers derived through (a1) give a necessary (though not sufficient) condition for the threshold value to be feasible: the product $d_{\text {nik }} d_{\text {ink }}$ takes on the same value for different values of its components and the smaller value would give us the true threshold. 


\section{App A3: Derivation of Regional Trade Data; Table of Regional Sectors}

In order to include the German regions into the calculations we start with value added data from national accounts which are available on the regional level from the German federal and state statistical offices ("Regionaldatenbank der statistischen Ämter des Bundes und der Länder”). This data is available for all 402 regions ("Kreise") disaggregated into 6 groups of NACE/ISIC industries which match directly with WIOD industries as can be seen in table App-A3-1.

Assuming that Germany's industry specific shares of value added in production $\left(\beta_{i k}+\eta_{i k}\right)$ hold for all regions, we can use the value added data to calculate a regions share in total German production for each industry.

We incorporate regions into the initial input-output table in three steps. Firstly, we replace all German rows in the table spreading the intermediate and final demand for German goods across regions according to their production shares. This means that a region with a high output in a certain industry will satisfy a larger share of demand from any trading partner than a region with low output in that particular industry.

Secondly, we replace all German intermediate demand columns by assuming that the German intermediate demand structure in each industry holds for all regions. Under this assumption we can use production shares to determine the intermediate demand levels of each region-industry from each trading partner. Hence, a region with a high output in, say, agriculture will have a higher demand for the typical intermediate goods of this sector than a region with low output in agriculture. Moreover, this region will also feature a higher trade level with whoever is the principal supplier of such intermediates.

Finally, we need to replace the German final demand column by splitting demand across regions. To do so, notice that the value of goods consumption is equal to $\alpha$ times a region's total expenditure given by eq. (14). Thus, a region's share of total German demand is $\frac{\alpha v_{n} L_{n}}{\sum_{i \in N^{j}} \alpha v_{i} L_{i}}=$ $\frac{\sum_{k=1}^{K}\left(\beta_{n k}+\eta_{n k}\right) R_{n k}+D_{n}}{\sum_{i \in N^{j}} \sum_{k=1}^{K}\left(\beta_{i k}+\eta_{i k}\right) R_{i k}+D_{i}}$, where the denominator sums across all German regions. Both the nominator and denominator of the RHS consist simply of the sum of value added and trade deficits. We assume that the latter are spread across regions according to total income ${ }^{28}$ and consequentially, the above expenditure shares can be calculated using only our value added data as $\frac{\alpha v_{n} L_{n}}{\sum_{i \in N^{j}} \alpha v_{i} L_{i}}=\frac{\sum_{k=1}^{K}\left(\beta_{n k}+\eta_{n k}\right) R_{n k}}{\sum_{i \in N^{j}} \sum_{k=1}^{K}\left(\beta_{i k}+\eta_{i k}\right) R_{i k}}$.

28 Though not in the model, the implicit underlying assumption to justify this decision is that of a constant saving rate across German regions. 
Table App-A3-1: Regional sectors

\begin{tabular}{|c|c|c|c|}
\hline \multirow{2}{*}{$\begin{array}{l}\text { WIOD } \\
\text { Sector }\end{array}$} & \multirow[b]{2}{*}{ Description } & \multicolumn{2}{|c|}{ This Paper: } \\
\hline & & Sector & Label \\
\hline 1 & Crop and animal production, hunting and related service activities & & \\
\hline 2 & Forestry and logging & 1 & Agricultural \\
\hline 3 & Fishing and aquaculture & & \\
\hline 4 & Mining and quarrying & & \\
\hline 5 & Food products, beverages and tobacco products & & \\
\hline 6 & Textiles, wearing apparel and leather products & & \\
\hline 7 & Wood, cork, except furniture; articles of straw and plaiting materials & & \\
\hline 8 & Paper and paper products & & \\
\hline 9 & Printing and reproduction of recorded media & & \\
\hline 10 & Coke and refined petroleum products & & \\
\hline 11 & Chemicals and chemical products & & \\
\hline 12 & Basic pharmaceutical products and pharmaceutical preparations & & \\
\hline 13 & Rubber and plastic products & & \\
\hline 14 & Other non-metallic mineral products & & \\
\hline 15 & Basic metals & 2 & Manufacturing \\
\hline 16 & Fabricated metal products, except machinery and equipment & & \\
\hline 17 & Computer, electronic and optical products & & \\
\hline 18 & Electrical equipment & & \\
\hline 19 & Machinery and equipment n.e.c. & & \\
\hline 20 & Motor vehicles, trailers and semi-trailers & & \\
\hline 21 & Other transport equipment & & \\
\hline 22 & Furniture; other manufacturing & & \\
\hline 23 & Repair and installation of machinery and equipment & & \\
\hline 24 & Electricity, gas, steam and air conditioning supply & & \\
\hline 25 & Water collection, treatment and supply & & \\
\hline 26 & Sewerage; waste collection, treatment and disposal activities; & & \\
\hline 27 & Construction & 3 & Construction \\
\hline 28 & Wholesale, retail trade \& repair of motor vehicles and motorcycles & & \\
\hline 29 & Wholesale trade, except of motor vehicles and motorcycles & & \\
\hline 30 & Retail trade, except of motor vehicles and motorcycles & & \\
\hline 31 & Land transport and transport via pipelines & & \\
\hline 32 & Water transport & & \\
\hline 33 & Air transport & & \\
\hline 34 & Warehousing and support activities for transportation & 4 & Communicati \\
\hline 35 & Postal and courier activities & & \\
\hline 36 & Accommodation and food service activities & & \\
\hline 37 & Publishing activities & & \\
\hline 38 & $\begin{array}{l}\text { Motion picture, video and television programme production, sound } \\
\text { recording and music publishing activities; broadcasting activities }\end{array}$ & & \\
\hline 39 & Telecommunications & & \\
\hline 40 & Computer programming, consultancy; information service activities & & \\
\hline 41 & Financial service activities, except insurance and pension funding & & \\
\hline 42 & Insurance, pension funding, except compulsory social security & & \\
\hline 43 & Activities auxiliary to financial services and insurance activities & & \\
\hline 44 & Legal, accounting activities; head offices; management consultancy & 5 & $\begin{array}{l}\text { Financial, } \\
\text { Business }\end{array}$ \\
\hline 45 & Architectural and engineering activities; technical testing and analysis & & \\
\hline 46 & Scientific research and development & & \\
\hline 47 & Advertising and market research & & \\
\hline 48 & Other professional, scientific, technical activities; veterinary activities & & \\
\hline 49 & Administrative and support service activities & & \\
\hline 50 & Public administration and defence; compulsory social security & & \\
\hline 51 & Education & & \\
\hline 52 & Human health and social work activities & & $\begin{array}{l}\text { Government, } \\
\text { Health }\end{array}$ \\
\hline 53 & Other service activities & 6 & Health, \\
\hline 54 & $\begin{array}{l}\text { Activities of households as employers; undifferentiated goods- and } \\
\text { services-producing activities of households for own use }\end{array}$ & & \\
\hline 55 & Activities of extraterritorial organizations and bodies & & \\
\hline
\end{tabular}




\title{
Supplementary Web Appendix - Not for publication
}

\author{
for: How Deep is Your Love? A Quantitative Spatial Analysis of the \\ Transatlantic Trade Partnership
}

By Oliver Krebs and Michael Pflüger

S1: List of symbols

S2a: Sector matching for the Aichele et al. (2016) scenario

S2b: Sector matching for the Francois et al (2013) scenario

S2c: Sector matching for the Fontagné et al. (2013) scenario

S3: Detailed regional effects in the extreme scenario 


\section{S1: List of symbols}

\begin{tabular}{|c|c|}
\hline$\alpha$ & share of housing in consumption \\
\hline$\beta_{n k}$ & cost share of labor \\
\hline$C_{n}$ & goods and services consumption index in $\mathrm{n}$ \\
\hline$C_{n k}$ & consumption index of industry $\mathrm{k}$ goods in $\mathrm{n}$ \\
\hline$c_{n k}$ & cost of an input bundle in industry $\mathrm{k}$ in location $\mathrm{n}$ \\
\hline$D_{n}$ & trade deficit of location $n$ \\
\hline$d_{n i k}$ & iceberg trade costs for shipping an industry $\mathrm{k}$ good from location $\mathrm{i}$ to $\mathrm{n}$ \\
\hline$\delta_{n C}^{k}$ & share of industry $\mathrm{k}$ in consumption of individuals from $\mathrm{n}$ \\
\hline$\delta_{n j}^{k}$ & $\begin{array}{l}\text { share of industry } \mathrm{k} \text { in intermediate demand of firms from industry } \mathrm{j} \text { and } \\
\text { location } \mathrm{n}\end{array}$ \\
\hline$\eta_{n k}$ & cost share of land \\
\hline$F_{n k}\left(z_{n k}\right)$ & $\begin{array}{l}\text { location and industry specific Frechet distribution function for productivity } \\
\text { draws }\end{array}$ \\
\hline$\gamma_{k}$ & calculatory constant \\
\hline$H_{n}$ & housing stock in $\mathrm{n}$ \\
\hline$H_{n}^{C}$ & private housing consumption \\
\hline$i$ & index for locations/countries \\
\hline$j$ & index for industries/sectors \\
\hline$k$ & index for industries/sectors \\
\hline$K$ & number of sectors \\
\hline$L_{n}$ & number of workers in $n$ \\
\hline $\bar{L}^{m}$ & worker endowment of $\mathrm{m}$ \\
\hline$\lambda_{n}^{m}$ & share of workers of location group m living in location $n$ \\
\hline$m$ & index for subsets (groups) of locations \\
\hline$N$ & number of locations \\
\hline$N^{m}$ & location group $=$ set of locations \\
\hline$n$ & index for locations \\
\hline$\omega$ & index for varieties \\
\hline$P_{n}$ & price index for consumption in location $n$ \\
\hline$P_{n k}$ & price index for industry $\mathrm{k}$ goods in location $\mathrm{n}$ \\
\hline$p_{\text {nik }}(\omega)$ & $\begin{array}{l}\text { price for variety } \omega \text { of industry } k \text { offered to consumers in } n \text { by a location } i \\
\text { firm }\end{array}$ \\
\hline$\pi_{\text {nik }}$ & share of location $\mathrm{i}$ in the expenditure of location $\mathrm{n}$ on industry $\mathrm{k}$ goods \\
\hline$q_{n k}(\omega)$ & consumption of variety $\omega$ from industry $\mathrm{k}$ by an individual from $\mathrm{n}$ \\
\hline$R_{n k}$ & revenue of industry $\mathrm{k}$ in location $\mathrm{n}$ \\
\hline$r_{n}$ & rental rates of land in $n$ \\
\hline$\rho_{n k}$ & price index for intermediate demand of an industry $\mathrm{k}$ firm in location $\mathrm{n}$ \\
\hline$\sigma_{k}$ & elasticity of substitution between varieties in industry $\mathrm{k}$ \\
\hline$T_{n k}$ & measure of the average productivity in industry $\mathrm{k}$ in location $\mathrm{n}$ \\
\hline$\theta_{k}$ & measure of the density of productivities \\
\hline$U_{n}$ & utility of a consumer in $n$ \\
\hline$V_{n}$ & indirect utility $=$ real income of a worker in $n$ \\
\hline$v_{n}$ & total income of one worker in $\mathrm{n}$ \\
\hline$W_{n}$ & total labor income of location $n$ \\
\hline$w_{n}$ & wages in $n$ \\
\hline$Y_{n}$ & total income of location $n$ \\
\hline$z_{n k}(\omega)$ & productivity draw of a firm in location $\mathrm{n}$ and industry k producing variety $\omega$ \\
\hline
\end{tabular}


S2a: Sector matching for the Aichele et al (2014) scenario

\begin{tabular}{|c|c|c|}
\hline Aichele et al. & Our Sector & Barrier Reduction \\
\hline Grains \& Crops & Crop and Animal Production & 0,877369 \\
\hline Forestry & Forestry & 0,981851 \\
\hline Fishing & Fishing & 1,000000 \\
\hline Mining & Mininig & 0,705666 \\
\hline Livestock \& Meat Products & Food, Beverages, Tobacco & 0,826172 \\
\hline \multicolumn{3}{|l|}{ Textiles } \\
\hline \multicolumn{3}{|l|}{ Leather } \\
\hline Wood Products & Wood & 0,820444 \\
\hline Paper products, publishing & Paper, Printing & 0,866693 \\
\hline \multirow{2}{*}{$\begin{array}{l}\text { Petroleum, coal products } \\
\text { chemical, Rubber, plastic } \\
\text { products }\end{array}$} & Chemicals, Pharmaceutical & 0,829681 \\
\hline & Plastics & 0,829681 \\
\hline Mineral products & Non-Metallic Minerals & 0,918624 \\
\hline ferrous metals & Basic Metals & 0,589330 \\
\hline metal products & Fabricated Metals & 0,774411 \\
\hline \multirow{2}{*}{ Electronic equipment } & Computer & 0,722792 \\
\hline & Electrical & 0,722792 \\
\hline Machinery and equipment & Machinery n.e.c & 0,889914 \\
\hline $\begin{array}{l}\text { motor vehicles } \\
\text { transport equipment nec }\end{array}$ & Transport Equipment & 0,756456 \\
\hline Manufactures nec & Other Manufacturing & 0,831424 \\
\hline $\begin{array}{l}\text { Gas } \\
\text { Water }\end{array}$ & Utilities & 0,909102 \\
\hline Construction & Construction & 0,924003 \\
\hline \multirow{2}{*}{ Trade } & Wholesale & 0,887826 \\
\hline & Retail & 0,887826 \\
\hline Transport nec & Land Transport & 0,907103 \\
\hline Sea transport & Water Transport & 0,929290 \\
\hline Air transport & Air Transport & 0,951221 \\
\hline Transport nec & Other Transport, Postal & 0,907103 \\
\hline Recreational services & Hotels, Restaurants & 0,938222 \\
\hline Communication & Telecommunications & 0,917205 \\
\hline $\begin{array}{l}\text { Financial services nec } \\
\text { Insurance }\end{array}$ & Financial, Insurance & 0,908861 \\
\hline Business services & Professional Services & 0,870564 \\
\hline \multirow{5}{*}{$\begin{array}{l}\text { PubAdmin/Defence/ } \\
\text { Health/Education }\end{array}$} & Administrative Services & 0,912599 \\
\hline & Public Admin., Defense & 0,912599 \\
\hline & Education & 0,912599 \\
\hline & Health & 0,912599 \\
\hline & Other Services & 0,912599 \\
\hline
\end{tabular}

Legend: We use table 1 and 2 from Aichele et al (2016) together with their estimates for $\theta$ to calculate the coefficients $\delta_{\text {shallow }}$ and $\delta_{\text {deep }}$. Ignoring tariff changes, the reduction in trade barriers resulting from a deep trade agreement can then be calculated as $e^{\delta_{\text {shallow }}+\delta_{\text {deep }}}-1$. 
S2b: Sector matching for the Francois et al (2013) CEPR/EU-Commission scenario

\begin{tabular}{|c|c|c|c|}
\hline Francois et al. & Our Sector & $\hat{d}_{U S \rightarrow E U}$ & $\hat{d}_{E U \rightarrow U S}$ \\
\hline \multirow{3}{*}{$\begin{array}{l}\text { Agriculture, forestry, } \\
\text { fishing }\end{array}$} & Crop and Animal Production & 0,99108 & 0,99108 \\
\hline & Forestry & 0,99108 & 0,99108 \\
\hline & Fishing & 0,99108 & 0,99108 \\
\hline Other primary sectors & Mininig & 1 & 1 \\
\hline Food and beverages & Food, Beverages, Tobacco & 0,909439 & 0,894259 \\
\hline Textiles and clothing & Textiles, Leather & 0,959732 & 0,964225 \\
\hline \multirow{2}{*}{ Wood and paper products } & Wood & 0,974618 & 0,982126 \\
\hline & Paper, Printing & 0,974618 & 0,982126 \\
\hline Chemicals & Chemicals, Pharmaceutical & 0,97007 & 0,959908 \\
\hline \multirow{2}{*}{ Average manufacturing } & Plastics & 0,955761 & 0,949362 \\
\hline & Non-Metallic Minerals & 0,955761 & 0,949362 \\
\hline \multirow{2}{*}{ Metal and metal products } & Basic Metals & 0,973414 & 0,963675 \\
\hline & Fabricated Metals & 0,973414 & 0,963675 \\
\hline \multirow{3}{*}{ Average manufacturing } & Computer & 0,955761 & 0,949362 \\
\hline & Electrical & 0,955761 & 0,949362 \\
\hline & Machinery n.e.c & 0,955761 & 0,949362 \\
\hline Motor Vehicles & Transport Equipment & 0,949203 & 0,947161 \\
\hline \multirow{2}{*}{ Average manufacturing } & Other Manufacturing & 0,955761 & 0,949362 \\
\hline & Utilities & 0,955761 & 0,949362 \\
\hline Construction & Construction & 0,989006 & 0,993902 \\
\hline \multirow{3}{*}{ Average services } & Wholesale & 0,980415 & 0,979568 \\
\hline & Retail & 0,980415 & 0,979568 \\
\hline & Land Transport & 0,980415 & 0,979568 \\
\hline Transport water & Water Transport & 0,981481 & 0,981481 \\
\hline Transport air & Air Transport & 0,995098 & 0,995098 \\
\hline \multirow{2}{*}{ Average services } & Other Transport, Postal & 0,980415 & 0,979568 \\
\hline & Hotels, Restaurants & 0,980415 & 0,979568 \\
\hline Communications & Telecommunications & 0,973814 & 0,995821 \\
\hline $\begin{array}{l}\text { Financial } \\
\text { Insurance }\end{array}$ & Financial, Insurance & 0,975125 & 0,949867 \\
\hline Business and ICT & Professional Services & 0,967581 & 0,990616 \\
\hline \multirow{4}{*}{$\begin{array}{l}\text { Personal, cultural, other } \\
\text { services }\end{array}$} & Administrative Services & 0,989464 & 0,993902 \\
\hline & Public Admin., Defense & 0,989464 & 0,993902 \\
\hline & Education & 0,989464 & 0,993902 \\
\hline & Health & 0,989464 & 0,993902 \\
\hline Average services & Other Services & 0,980415 & 0,979568 \\
\hline
\end{tabular}

Legend: We combine the $25 \%$ NTB reduction suggested as ambitious scenario ${ }^{29}$ in Table 4 p. 28 of Francois et al. (2013) with the NTBs given in Table 2 p. 20 and supplement the information for the textiles sector from Table III.1 in the appendix to Ecorys (2009). For Agriculture and Mining ("Other primary sectors") we rely on the combined measure of NTBs and tariffs - thus potentially overstating the size of the barriers and subsequently the reduction - reported for exports from the EU to the US in Table 5 p. 31 of Francois et al. (2013) and assume them to be symmetrically. For sectors without an obvious match we rely on the reported average values for services and manufacturing respectively.

${ }^{29}$ Due to the differences in modelling and data availability we focus only on NTBs and abstract from spillovers and government procurement effects of the original ambitious scenario. 


\section{S2c: Sector matching for the Fontagné et al. (2013) scenario}

For the agriculture and manufacturing sectors we follow Fontagné et al. (2013) and rely on the dataset of Kee et al. (2009) available online. The dataset contains bilateral NTB barriers for a large set of countries and goods on the HS6 level which we match to our industries. Following Fontagné et al. (2013) we aggregate sectors using simple averages.

For the services sectors NTBs stem from Fontagné et al. (2011). We match their sectors to ours according to the following scheme:

\begin{tabular}{ll}
\hline Our Sector & Fontagné t al. (2011) \\
\hline Construction & cns - Construction \\
Wholesale & trd - trade \\
\hline Retail & trd - trade \\
Land Transport & trn - transport \\
Water Transport & wtp - water transport \\
\hline Air Transport & trn - transport \\
\hline Other Transport, Postal & trn - transport \\
\hline Hotels, Restaurants & average \\
\hline Telecommunications & cmn - communication \\
\hline Financial, Insurance & ofi - other finance \\
\hline Professional Services & Isr - insurance \\
\hline Administrative Services & obs - other business \\
\hline Public Admin., Defense & osg - other services \\
\hline Education & osg - other services \\
\hline Health & osg - other services \\
\hline Other Services & osg - other services \\
\hline Leger & osg - other services \\
\hline
\end{tabular}

Legend: Other servies (osg) comprise education, health, defense and public administration

For countries for which data is not (Malta) or partially not available (Bulgaria, Cyprus, Slovakia) as well as for unmatched sectors we use the sector averages given in Fontagné et al. (2013). Taken together we can construct a matrix of bilateral NTBs between EU members and the US for each sector and thus calculate the bilateral, sector specific $\hat{d}$ values that result from the reference scenario in Fontagné et al. (2013), i.e. a 25\% cut of NTBs across the board. 
S3: Detailed regional effects in the extreme scenario

\begin{tabular}{|c|c|c|c|c|c|c|c|c|c|}
\hline & \multicolumn{2}{|c|}{ real income } & \multicolumn{2}{|c|}{ prices } & \multicolumn{2}{|c|}{ wages } & \multicolumn{2}{|c|}{ rents } & \multirow{2}{*}{$\begin{array}{l}\text { population } \\
\text { mobile }\end{array}$} \\
\hline & immobile & mobile & immobile & mobile & immobile & mobile & immobile & mobile & \\
\hline Ahrweiler. Landkreis & $0.43 \%$ & $0.46 \%$ & $0.06 \%$ & $0.07 \%$ & $0.48 \%$ & $0.52 \%$ & $0.42 \%$ & $0.39 \%$ & $-0.07 \%$ \\
\hline $\begin{array}{l}\text { Aichach-Friedberg. } \\
\text { Landkreis }\end{array}$ & $0.47 \%$ & $0.46 \%$ & $0.06 \%$ & $0.07 \%$ & $0.52 \%$ & $0.52 \%$ & $0.43 \%$ & $0.45 \%$ & $0.02 \%$ \\
\hline Alb-Donau-Kreis & $0.53 \%$ & $0.46 \%$ & $0.06 \%$ & $0.06 \%$ & $0.59 \%$ & $0.51 \%$ & $0.49 \%$ & $0.61 \%$ & $0.19 \%$ \\
\hline Altenburger Land. Kreis & $0.47 \%$ & $0.46 \%$ & $0.06 \%$ & $0.07 \%$ & $0.52 \%$ & $0.52 \%$ & $0.45 \%$ & $0.47 \%$ & $0.03 \%$ \\
\hline $\begin{array}{l}\text { Altenkirchen (Westerwald). } \\
\text { Landkreis }\end{array}$ & $0.50 \%$ & $0.46 \%$ & $0.06 \%$ & $0.06 \%$ & $0.56 \%$ & $0.51 \%$ & $0.46 \%$ & $0.54 \%$ & $0.11 \%$ \\
\hline Altmarkkreis Salzwedel & $0.46 \%$ & $0.46 \%$ & $0.06 \%$ & $0.07 \%$ & $0.52 \%$ & $0.52 \%$ & $0.44 \%$ & $0.45 \%$ & $0.01 \%$ \\
\hline Altoetting. Landkreis & $0.64 \%$ & $0.46 \%$ & $0.05 \%$ & $0.06 \%$ & $0.68 \%$ & $0.49 \%$ & $0.61 \%$ & $0.90 \%$ & $0.47 \%$ \\
\hline Alzey-Worms. L & $0.41 \%$ & $0.46 \%$ & $0.06 \%$ & $0.07 \%$ & $0.47 \%$ & $0.52 \%$ & $0.39 \%$ & $0.32 \%$ & $-0.13 \%$ \\
\hline Amberg & $0.52 \%$ & $0.46 \%$ & $0.06 \%$ & $0.06 \%$ & $0.57 \%$ & $0.51 \%$ & $0.49 \%$ & $0.59 \%$ & $0.16 \%$ \\
\hline Amberg-Sulzbach. Landl & $0.49 \%$ & $0.46 \%$ & $0.06 \%$ & $0.06 \%$ & $0.55 \%$ & $0.52 \%$ & $0.46 \%$ & $0.51 \%$ & $0.09 \%$ \\
\hline Ammerland. Landkreis & $0.43 \%$ & $0.46 \%$ & $0.06 \%$ & $0.07 \%$ & $0.49 \%$ & $0.52 \%$ & $0.41 \%$ & $0.38 \%$ & $-0.07 \%$ \\
\hline Anha & $0.46 \%$ & $0.46 \%$ & $0.06 \%$ & $0.07 \%$ & $0.52 \%$ & $0.52 \%$ & $0.43 \%$ & $0.45 \%$ & $0.01 \%$ \\
\hline Ansbach & $0.48 \%$ & $0.46 \%$ & $0.06 \%$ & $0.06 \%$ & $0.53 \%$ & $0.51 \%$ & $0.45 \%$ & $0.49 \%$ & $0.04 \%$ \\
\hline Ansb & $0.52 \%$ & $0.46 \%$ & $0.06 \%$ & $0.06 \%$ & $0.57 \%$ & $0.51 \%$ & $0.48 \%$ & $0.57 \%$ & $0.15 \%$ \\
\hline As & $0.43 \%$ & $0.46 \%$ & $0.06 \%$ & $0.07 \%$ & $0.49 \%$ & $0.52 \%$ & $0.40 \%$ & $0.36 \%$ & $-0.08 \%$ \\
\hline Aschaffenburg. La & $0.43 \%$ & $0.46 \%$ & $0.06 \%$ & $0.07 \%$ & $0.49 \%$ & $0.52 \%$ & $0.39 \%$ & $0.36 \%$ & $-0.07 \%$ \\
\hline Augs & $0.47 \%$ & $0.46 \%$ & $0.06 \%$ & $0.06 \%$ & $0.52 \%$ & $0.52 \%$ & $0.44 \%$ & $0.46 \%$ & $0.02 \%$ \\
\hline Augsburg. Landkreis & $0.49 \%$ & $0.46 \%$ & $0.06 \%$ & $0.06 \%$ & $0.55 \%$ & $0.52 \%$ & $0.45 \%$ & $0.51 \%$ & $0.09 \%$ \\
\hline Aurich & $0.40 \%$ & $0.46 \%$ & $0.07 \%$ & $0.07 \%$ & $0.45 \%$ & $0.52 \%$ & $0.40 \%$ & $0.30 \%$ & $-0.16 \%$ \\
\hline AUS & $-0.01 \%$ & $-0.01 \%$ & $-0.18 \%$ & $-0.18 \%$ & $-0.18 \%$ & $-0.18 \%$ & $-0.18 \%$ & $-0.18 \%$ & $0.00 \%$ \\
\hline AUT & $0.24 \%$ & $0.24 \%$ & $0.12 \%$ & $0.12 \%$ & $0.37 \%$ & $0.37 \%$ & $0.30 \%$ & $0.30 \%$ & $0.00 \%$ \\
\hline Bad D & $0.44 \%$ & $0.46 \%$ & $0.06 \%$ & $0.07 \%$ & $9 \%$ & $\%$ & $0.42 \%$ & $0.39 \%$ & $-0.05 \%$ \\
\hline Bad Kissinger & $0.42 \%$ & $0.46 \%$ & $0.07 \%$ & $0.07 \%$ & $0.47 \%$ & $0.52 \%$ & $0.42 \%$ & $0.36 \%$ & $-0.11 \%$ \\
\hline Bad & $0.47 \%$ & $0.46 \%$ & $0.06 \%$ & $0.06 \%$ & $0.52 \%$ & $0.52 \%$ & $0.44 \%$ & $0.46 \%$ & $0.02 \%$ \\
\hline $\begin{array}{l}\text { Bad Toelz-Wolfratshausen. } \\
\text { Landkreis }\end{array}$ & $0.44 \%$ & $0.46 \%$ & $0.06 \%$ & $0.07 \%$ & $0.50 \%$ & $0.52 \%$ & $0.42 \%$ & $0.40 \%$ & $-0.04 \%$ \\
\hline $\begin{array}{l}\text { Baden-Baden. Kreisfreie } \\
\text { Stadt }\end{array}$ & $0.40 \%$ & $0.46 \%$ & $0.06 \%$ & $0.07 \%$ & $0.46 \%$ & $0.52 \%$ & $0.39 \%$ & $0.30 \%$ & -0. \\
\hline Bamberg & $0.50 \%$ & $0.46 \%$ & $0.06 \%$ & $0.06 \%$ & $0.55 \%$ & $0.51 \%$ & $0.46 \%$ & $0.53 \%$ & $0.10 \%$ \\
\hline Bamberg. L & $0.48 \%$ & $0.46 \%$ & $0.06 \%$ & $0.07 \%$ & $0.53 \%$ & $0.52 \%$ & $0.44 \%$ & $0.48 \%$ & $0.05 \%$ \\
\hline Barnim. Lar & $0.41 \%$ & $0.46 \%$ & $0.07 \%$ & $0.07 \%$ & $0.46 \%$ & $0.52 \%$ & $0.42 \%$ & $0.34 \%$ & $-0.14 \%$ \\
\hline Bautzen. La & $0.48 \%$ & $0.46 \%$ & $0.06 \%$ & $0.07 \%$ & $0.53 \%$ & $0.52 \%$ & $0.45 \%$ & $0.49 \%$ & $0.05 \%$ \\
\hline Bayreuth & $0.45 \%$ & $0.46 \%$ & $0.06 \%$ & $0.07 \%$ & $0.51 \%$ & $0.52 \%$ & $0.45 \%$ & $0.44 \%$ & $-0.01 \%$ \\
\hline Bayreuth. Landkreis & $0.45 \%$ & $0.46 \%$ & $0.06 \%$ & $0.07 \%$ & $0.50 \%$ & $0.52 \%$ & $0.42 \%$ & $0.40 \%$ & $-0.03 \%$ \\
\hline BEL & $0.81 \%$ & $0.81 \%$ & $-0.23 \%$ & $-0.23 \%$ & $0.63 \%$ & $0.63 \%$ & $0.53 \%$ & $0.53 \%$ & $0.00 \%$ \\
\hline $\begin{array}{l}\text { Berchtesgadener } \\
\text { Landkreis }\end{array}$ & $0.43 \%$ & $0.46 \%$ & $0.06 \%$ & $0.07 \%$ & $0.48 \%$ & $0.52 \%$ & $0.42 \%$ & $0.38 \%$ & $-0.08 \%$ \\
\hline Bergstrasse. Landkreis & $0.48 \%$ & $0.46 \%$ & $0.06 \%$ & $0.06 \%$ & $0.54 \%$ & $0.52 \%$ & $0.44 \%$ & $0.48 \%$ & $0.06 \%$ \\
\hline Berlin & $0.40 \%$ & $0.46 \%$ & $0.06 \%$ & $0.07 \%$ & $0.45 \%$ & $0.52 \%$ & $0.40 \%$ & $0.31 \%$ & $-0.16 \%$ \\
\hline $\begin{array}{l}\text { Bernkastel-Wittlich. } \\
\text { Landkreis }\end{array}$ & 0 & $\%$ & $\%$ & $0 . c$ & $\%$ & $\%$ & $\%$ & $\%$ & $0.13 \%$ \\
\hline BGR & $0.14 \%$ & $0.14 \%$ & $-0.10 \%$ & $-0.10 \%$ & $0.05 \%$ & $0.05 \%$ & $0.05 \%$ & $0.05 \%$ & $0.00 \%$ \\
\hline Biberach. Landkreis & $0.59 \%$ & $0.46 \%$ & $0.05 \%$ & $0.06 \%$ & $0.64 \%$ & $0.50 \%$ & $0.55 \%$ & $0.76 \%$ & $0.34 \%$ \\
\hline
\end{tabular}




\begin{tabular}{|c|c|c|c|c|c|c|c|c|c|}
\hline Bielefeld. Kreisfreie Stadt & $0.44 \%$ & $0.46 \%$ & $0.06 \%$ & $0.07 \%$ & $0.49 \%$ & $0.52 \%$ & $0.42 \%$ & $0.39 \%$ & $-0.06 \%$ \\
\hline Birkenfeld. Landkreis & $0.47 \%$ & $0.46 \%$ & $0.06 \%$ & $0.07 \%$ & $0.52 \%$ & $0.52 \%$ & $0.45 \%$ & $0.47 \%$ & $0.03 \%$ \\
\hline Bochum. Kreisfreie Stadt & $0.42 \%$ & $0.46 \%$ & $0.06 \%$ & $0.07 \%$ & $0.47 \%$ & $0.52 \%$ & $0.41 \%$ & $0.35 \%$ & $-0.11 \%$ \\
\hline Bodenseekreis & $0.58 \%$ & $0.46 \%$ & $0.05 \%$ & $0.06 \%$ & $0.63 \%$ & $0.50 \%$ & $0.53 \%$ & $0.72 \%$ & $0.30 \%$ \\
\hline Boeblingen. Landkreis & $0.58 \%$ & $0.46 \%$ & $0.05 \%$ & $0.06 \%$ & $0.63 \%$ & $0.50 \%$ & $0.52 \%$ & $0.72 \%$ & $0.31 \%$ \\
\hline Boerde. Landkreis & $0.52 \%$ & $0.46 \%$ & $0.06 \%$ & $0.06 \%$ & $0.57 \%$ & $0.51 \%$ & $0.47 \%$ & $0.57 \%$ & $0.14 \%$ \\
\hline Bonn. Kreisfreie Stadt & $0.34 \%$ & $0.46 \%$ & $0.07 \%$ & $0.07 \%$ & $0.39 \%$ & $0.52 \%$ & $0.37 \%$ & $0.18 \%$ & $-0.32 \%$ \\
\hline Borken. Kreis & $0.49 \%$ & $0.46 \%$ & $0.06 \%$ & $0.06 \%$ & $0.55 \%$ & $0.52 \%$ & $0.46 \%$ & $0.51 \%$ & $0.09 \%$ \\
\hline Bottrop. Kreisfreie Stadt & $0.43 \%$ & $0.46 \%$ & $0.06 \%$ & $0.07 \%$ & $0.48 \%$ & $0.52 \%$ & $0.42 \%$ & $0.38 \%$ & $-0.09 \%$ \\
\hline BRA & $0.00 \%$ & $0.00 \%$ & $-0.18 \%$ & $-0.18 \%$ & $-0.19 \%$ & $-0.19 \%$ & $-0.19 \%$ & $-0.19 \%$ & $0.00 \%$ \\
\hline $\begin{array}{l}\text { Brandenburg an der Havel. } \\
\text { Kreisfreie Stadt }\end{array}$ & $0.46 \%$ & $0.46 \%$ & $0.06 \%$ & $0.07 \%$ & $0.52 \%$ & $0.52 \%$ & $0.45 \%$ & $0.46 \%$ & 0 \\
\hline $\begin{array}{l}\text { Braunschweig. Kreisfreie } \\
\text { Stadt }\end{array}$ & $0.45 \%$ & $0.46 \%$ & $0.06 \%$ & $0.07 \%$ & $0.51 \%$ & $0.52 \%$ & $0.43 \%$ & $0.42 \%$ & $-0.02 \%$ \\
\hline $\begin{array}{l}\text { Breisgau-Hochschwarzwald. } \\
\text { Landkreis }\end{array}$ & $0.46 \%$ & $0.46 \%$ & $0.06 \%$ & $0.07 \%$ & $0.51 \%$ & $0.52 \%$ & $0.43 \%$ & $0.43 \%$ & $-0.01 \%$ \\
\hline Bremen. Kreisfreie Stadt & $0.44 \%$ & $0.46 \%$ & $0.06 \%$ & $0.07 \%$ & $0.49 \%$ & $0.52 \%$ & $0.41 \%$ & $0.38 \%$ & $-0.06 \%$ \\
\hline $\begin{array}{l}\text { Bremerhaven. Kreisfreie } \\
\text { Stadt }\end{array}$ & 0.38 & $0.46 \%$ & $0.06 \%$ & $0.07 \%$ & $0.44 \%$ & $0.52 \%$ & $0.39 \%$ & $0.27 \%$ & $-0.20 \%$ \\
\hline Burgenlandkreis & $0.50 \%$ & $0.46 \%$ & $0.06 \%$ & $0.06 \%$ & $0.55 \%$ & $0.51 \%$ & $0.47 \%$ & $0.53 \%$ & $0.10 \%$ \\
\hline Calw. Landkreis & $0.47 \%$ & $0.46 \%$ & $0.06 \%$ & $0.06 \%$ & $0.53 \%$ & $0.52 \%$ & $0.45 \%$ & $0.48 \%$ & $0.04 \%$ \\
\hline CAN & $-0.06 \%$ & $-0.06 \%$ & $-0.30 \%$ & $-0.30 \%$ & $-0.36 \%$ & $-0.36 \%$ & $-0.33 \%$ & $-0.33 \%$ & $0.00 \%$ \\
\hline Celle. Landkreis & $0.48 \%$ & $0.46 \%$ & $0.06 \%$ & $0.06 \%$ & $0.53 \%$ & $0.52 \%$ & $0.45 \%$ & $0.49 \%$ & $0.04 \%$ \\
\hline Cham. Landkreis & $0.50 \%$ & $0.46 \%$ & $0.06 \%$ & $0.07 \%$ & $0.55 \%$ & $0.51 \%$ & $0.47 \%$ & $0.53 \%$ & $0.10 \%$ \\
\hline CHE & $-0.06 \%$ & $-0.06 \%$ & $-0.13 \%$ & $-0.13 \%$ & $-0.18 \%$ & $-0.18 \%$ & $-0.17 \%$ & $-0.17 \%$ & $0.00 \%$ \\
\hline Chemnitz. Stadt & $0.44 \%$ & $0.46 \%$ & $0.06 \%$ & $0.07 \%$ & $0.49 \%$ & $0.52 \%$ & $0.43 \%$ & $0.40 \%$ & $-0.06 \%$ \\
\hline $\mathrm{CHN}$ & $-0.02 \%$ & $-0.02 \%$ & $-0.21 \%$ & $-0.21 \%$ & $-0.23 \%$ & $-0.23 \%$ & $-0.23 \%$ & $-0.23 \%$ & $0.00 \%$ \\
\hline Cloppenburg. Landkreis & $0.48 \%$ & $0.46 \%$ & $0.06 \%$ & $0.07 \%$ & $0.54 \%$ & $0.52 \%$ & $0.45 \%$ & $0.49 \%$ & $0.06 \%$ \\
\hline Coburg & $0.48 \%$ & $0.46 \%$ & $0.06 \%$ & $0.06 \%$ & $0.53 \%$ & $0.52 \%$ & $0.43 \%$ & $0.46 \%$ & $0.04 \%$ \\
\hline Coburg. Landkreis & $0.54 \%$ & $0.46 \%$ & $0.06 \%$ & $0.06 \%$ & $0.59 \%$ & $0.51 \%$ & $0.49 \%$ & $0.62 \%$ & $0.20 \%$ \\
\hline Cochem-Zell. Landkreis & $0.40 \%$ & $0.46 \%$ & $0.07 \%$ & $0.07 \%$ & $0.46 \%$ & $0.52 \%$ & $0.41 \%$ & $0.33 \%$ & $-0.14 \%$ \\
\hline Coesfeld. Kreis & $0.44 \%$ & $0.46 \%$ & $0.06 \%$ & $0.07 \%$ & $0.49 \%$ & $0.52 \%$ & $0.42 \%$ & $0.40 \%$ & $-0.05 \%$ \\
\hline Cottbus. Kreisfreie Stadt & $0.39 \%$ & $0.46 \%$ & $0.06 \%$ & $0.07 \%$ & $0.44 \%$ & $0.52 \%$ & $0.42 \%$ & $0.32 \%$ & $-0.17 \%$ \\
\hline Cuxhaven. Landkreis & $0.39 \%$ & $0.46 \%$ & $0.07 \%$ & $0.07 \%$ & $0.44 \%$ & $0.52 \%$ & $0.39 \%$ & $0.29 \%$ & $-0.19 \%$ \\
\hline CYP & $0.09 \%$ & $0.09 \%$ & $-0.15 \%$ & $-0.15 \%$ & $-0.06 \%$ & $-0.06 \%$ & $-0.05 \%$ & $-0.05 \%$ & $0.00 \%$ \\
\hline CZE & $0.21 \%$ & $0.21 \%$ & $-0.04 \%$ & $-0.04 \%$ & $0.17 \%$ & $0.17 \%$ & $0.15 \%$ & $0.15 \%$ & $0.00 \%$ \\
\hline Dachau. Landkreis & $0.43 \%$ & $0.46 \%$ & $0.06 \%$ & $0.07 \%$ & $0.49 \%$ & $0.52 \%$ & $0.41 \%$ & $0.38 \%$ & $-0.06 \%$ \\
\hline $\begin{array}{l}\text { Dahme-Spreewald. } \\
\text { Landkreis }\end{array}$ & $36 \%$ & $0.46 \%$ & $7 \%$ & $0.07 \%$ & $\%$ & $0.53 \%$ & $5 \%$ & $\%$ & -( \\
\hline $\begin{array}{l}\text { Darmstadt-Dieburg. } \\
\text { Landkreis }\end{array}$ & $.43 \%$ & $0.46 \%$ & $0.06 \%$ & $0.07 \%$ & $0.49 \%$ & $0.52 \%$ & $0.41 \%$ & $0.37 \%$ & $-0.06 \%$ \\
\hline Darmstadt. Kreisfreie St & $0.45 \%$ & $0.46 \%$ & $0.06 \%$ & $0.06 \%$ & $0.51 \%$ & $0.52 \%$ & $0.43 \%$ & $0.42 \%$ & $-0.02 \%$ \\
\hline Deggendorf. Landkreis & $0.46 \%$ & $0.46 \%$ & $0.06 \%$ & $0.07 \%$ & $0.52 \%$ & $0.52 \%$ & $0.44 \%$ & $0.45 \%$ & $0.00 \%$ \\
\hline $\begin{array}{l}\text { Delmenhorst. Kreisfreie } \\
\text { Stadt }\end{array}$ & $0.40 \%$ & $0.46 \%$ & $0.06 \%$ & $0.07 \%$ & $0.46 \%$ & $0.52 \%$ & $0.41 \%$ & $0.33 \%$ & $4 \%$ \\
\hline $\begin{array}{l}\text { Dessau-Rosslau. Kreisfreie } \\
\text { Stadt }\end{array}$ & $0.45 \%$ & $0.46 \%$ & $0.06 \%$ & $0.07 \%$ & $0.50 \%$ & $0.52 \%$ & $0.44 \%$ & $0.44 \%$ & $-0.02 \%$ \\
\hline Diepholz. Landkreis & $0.45 \%$ & $0.46 \%$ & $0.06 \%$ & $0.07 \%$ & $0.51 \%$ & $0.52 \%$ & $0.42 \%$ & $0.41 \%$ & $-0.02 \%$ \\
\hline
\end{tabular}


Dillingen a.d.Donau. Landkreis

Dingolfing-Landau.

Landkreis

Dithmarschen. Landkreis

DNK

Donau-Ries. Landkreis

Donnersbergkreis

Dortmund. Kreisfreie Stadt

Dresden. Stadt

Dueren. Kreis

Duesseldorf. Kreisfreie Stadt

Duisburg. Kreisfreie Stadt

Ebersberg. Landkreis

Eichsfeld. Kreis

Eichstaett. Landkreis

Eifelkreis Bitburg-Pruem

Eisenach. krsfr. Stadt

Elbe-Elster. Landkreis

Emden. Kreisfreie Stadt

Emmendingen. Landkreis

Emsland. Landkreis

Ennepe-Ruhr-Kreis

Enzkreis

Erding. Landkreis

Erfurt. krsfr. Stadt

Erlangen

Erlangen-Hoechstadt.

Landkreis

Erzgebirgskreis

ESP

Essen. Kreisfreie Stadt

Esslingen. Landkreis

EST

Euskirchen. Kreis

FIN

Flensburg. Kreisfreie Stadt

Forchheim. Landkreis

FRA

Frankenthal (Pfalz).

Kreisfreie Stadt

Frankfurt (Oder). Kreisfreie

Stadt

Frankfurt am Main.

Kreisfreie Stadt

Freiburg im Breisgau.

Kreisfreie Stadt

Freising. Landkreis

Freudenstadt. Landkreis

\begin{tabular}{|c|c|c|c|c|c|c|c|c|}
\hline $0 \%$ & & $06 \%$ & & & & $0.46 \%$ & $.53 \%$ & \\
\hline $59 \%$ & $46 \%$ & $0.05 \%$ & $0.05 \%$ & $0.73 \%$ & $0.49 \%$ & $0.66 \%$ & $1.02 \%$ & \\
\hline & & & & & & & & \\
\hline $35 \%$ & $35 \%$ & $09 \%$ & $9 \%$ & & $\%$ & $\%$ & & $0 \%$ \\
\hline $56 \%$ & $46 \%$ & $.06 \%$ & $6 \%$ & & $\%$ & $\%$ & $\%$ & $25 \%$ \\
\hline $5 \%$ & $\%$ & & & & & & & \\
\hline$\%$ & & 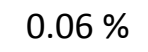 & & & & & & $\%$ \\
\hline $43 \%$ & $46 \%$ & $06 \%$ & & & & & & \\
\hline$\%$ & & & & & & & & $3 \%$ \\
\hline $36 \%$ & $\%$ & 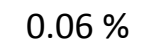 & & & & & & \\
\hline $0 \%$ & & & & & & & & \\
\hline $39 \%$ & $\%$ & & & & & & $\%$ & $7 \%$ \\
\hline $0 \%$ & & & & & & & & \\
\hline $46 \%$ & $\%$ & & $7 \%$ & & & & $\%$ & \\
\hline $49 \%$ & $46 \%$ & & & & & & & \\
\hline & & & & & & & & \\
\hline $45 \%$ & $46 \%$ & $\%$ & $\%$ & & $\%$ & & $\%$ & $3 \%$ \\
\hline $7 \%$ & & & & & & & & \\
\hline $51 \%$ & $46 \%$ & $\%$ & $0.06 \%$ & & & & & \\
\hline $50 \%$ & $46 \%$ & $.06 \%$ & $.06 \%$ & & & & & \\
\hline & & & & & & & & \\
\hline $5 \%$ & $5 \%$ & & & & & & & \\
\hline $38 \%$ & $\%$ & & & & & & & \\
\hline $0 \%$ & & & & & & & & \\
\hline $56 \%$ & $46 \%$ & $\%$ & $0.06 \%$ & & $\%$ & $\%$ & $\%$ & of \\
\hline $55 \%$ & & & $0.06 \%$ & & & & & \\
\hline & & & & & & & & \\
\hline 15 & $\%$ & & & & & & & \\
\hline $45 \%$ & $46 \%$ & 6 & $\%$ & & & & $\%$ & $2 \%$ \\
\hline$-g$ & & & & & & & & \\
\hline $18 \%$ & $18 \%$ & $.04 \%$ & $04 \%$ & & $\%$ & & $\%$ & $\%$ \\
\hline & & & & & & & & \\
\hline $27 \%$ & $\%$ & $\%$ & $\%$ & & & & $\%$ & \\
\hline & & & & & & & & \\
\hline & & & & & & & & \\
\hline & & & & & & & & \\
\hline & & & & & & & & \\
\hline r & & & & & & & & \\
\hline 50 & $0 \%$ & & & & & & $\%$ & \\
\hline $.72 \pi$ & $0.46 \%$ & $0.06 \%$ & $0.07 \%$ & & & & & \\
\hline & & & & & & & & \\
\hline & $40 \pi$ & $00 \%$ & $.06 \%$ & $.59 \%$ & $.51 \%$ & $0.49 \%$ & $0.62 \%$ & 0.2 \\
\hline
\end{tabular}


Freyung-Grafenau.

Landkreis

Friesland. Landkreis

Fuerstenfeldbruck.

Landkreis

Fuerth

Fuerth. Landkreis

Fulda. Landkreis

Garmisch-Partenkirchen. Landkreis

GBR

Gelsenkirchen. Kreisfreie

Stadt

Gera. krsfr. Stadt

Germersheim. Landkreis

Giessen. Landkreis

Gifhorn. Landkreis

Goeppingen. Landkreis

Goerlitz. Landkreis

Goettingen. Landkreis

Goslar. Landkreis

Gotha. Kreis

Grafschaft Bentheim.

Landkreis

GRC

Greiz. Kreis

Gross-Gerau. Landkreis

Guenzburg. Landkreis

Guetersloh. Kreis

Hagen. Kreisfreie Stadt

Halle (Saale). Kreisfreie

Stadt

Hamburg

Hameln-Pyrmont. Landkreis

Hamm. Kreisfreie Stadt

Harburg. Landkreis

Harz. Landkreis

Hassberge. Landkreis

Havelland. Landkreis

Heidekreis. Landkreis

Heidelberg. Kreisfreie Stadt

Heidenheim. Landkreis

Heilbronn. Kreisfreie Stadt

Heilbronn. Landkreis

Heinsberg. Kreis

Helmstedt. Landkreis

Herford. Kreis

Herne. Kreisfreie Stadt

$0.45 \%$

$0.43 \%$

$0.46 \%$

$0.06 \%$

$0.07 \%$

$0.50 \%$

$0.52 \%$

$0.43 \%$

$0.42 \%$

$-0.03 \%$

$0.40 \%$

$0.46 \%$

$0.06 \%$

$0.07 \%$

$0.48 \%$

$0.52 \%$

$0.42 \%$

$0.38 \%-0.08 \%$

$0.46 \% \quad 0.06 \% \quad 0.07 \%$

$0.46 \%$

$0.52 \%$

$0.39 \%$

$0.30 \%$

$-0.15 \%$

$0.45 \%$

$0.45 \%$

$0.46 \%$

$0.06 \%$

$0.07 \%$

$0.49 \%$

$0.52 \%$

$0.41 \%$

$0.39 \%$

$-0.05 \%$

$0.46 \% \quad 0.06 \% \quad 0.07 \%$

$0.51 \%$

$0.52 \%$

$0.43 \%$

$0.43 \%$

$-0.02 \%$

$0.37 \%$

$0.06 \%$

$0.50 \%$

$0.52 \%$

$0.42 \%$

$0.41 \%$

$-0.03 \%$

$0.44 \%$

$0.46 \%$

$0.07 \% \quad 0.07 \%$

$0.43 \%$

$0.52 \%$

$0.40 \%$

$0.27 \%$

$-0.22 \%$

$0.50 \%$

$0.44 \%$

$0.02 \%$

$0.02 \%$

$0.50 \%$

$0.50 \%$

$0.48 \%$

$0.48 \%$

$0.00 \%$

$0.42 \%$

$0.46 \%$

$0.63 \%$

$0.46 \%$

$0.06 \%$

$0.06 \%$

$0.55 \% \quad 0.51 \%$

$0.47 \%$

$0.54 \%$

$0.11 \%$

$0.42 \%$

$0.46 \%$

$0.05 \%$

$0.07 \%$

$0.47 \%$

$0.52 \%$

$0.43 \%$

$0.38 \%$

$-0.10 \%$

$0.42 \%$

$0.46 \%$

$0.06 \%$

$0.67 \%$

$0.50 \%$

$0.58 \%$

$0.85 \%$

$0.43 \%$

$0.50 \%$

$0.46 \%$

$0.06 \%$

$0.07 \%$

$0.48 \%$

$52 \%$

$0.41 \%$

$0.36 \%$

$-0.09 \%$

$0.50 \%$

$0.46 \%$

$0.06 \%$

$0.06 \%$

$0.48 \%$

$0.41 \%$

$0.36 \%$

$-0.09 \%$

$0.44 \%$

$0.46 \%$

$0.06 \%$

$0.06 \%$

$0.55 \%$

$0.51 \%$

$0.46 \%$

$0.53 \%$

$0.10 \%$

$0.46 \%$

$0.46 \%$

$0.06 \%$

$0.07 \%$

$0.56 \%$

$0.51 \%$

$0.47 \%$

$0.55 \%$

$0.12 \%$

$0.51 \%$

$0.46 \%$

$0.06 \%$

$0.07 \%$

$0.50 \%$

$0.52 \%$

$0.43 \%$

$0.42 \%$

$-0.04 \%$

$0.51 \%$

$0.52 \%$

$0.43 \%$

$0.44 \%$

$0.00 \%$

$0.47 \%$

$0.46 \%$

$0.56 \%$

$0.51 \%$

$0.48 \%$

$0.56 \%$

$0.13 \%$

$0.10 \%$

$0.10 \%$

$0.07 \%$

$0.53 \%$

$0.52 \%$

$0.44 \%$

$0.47 \%$

$0.04 \%$

$0.46 \%$

$0.46 \%$

$-0.28 \%$

$-0.28 \%$

$-0.17 \%$

$-0.17 \%$

$-0.19 \%$

$-0.19 \%$

$0.00 \%$

$0.48 \%$

$0.46 \%$

$0.52 \%$

$0.52 \%$

$0.44 \%$

$0.45 \%$

$0.00 \%$

$0.56 \%$

$0.46 \%$

$0.06 \%$

$0.06 \%$

$0.54 \%$

$0.52 \%$

$0.43 \%$

$0.47 \%$

$0.05 \%$

$0.52 \%$

$0.46 \%$

$0.61 \%$

$0.51 \%$

$0.52 \%$

$0.68 \%$

$0.26 \%$

$0.48 \%$

$0.46 \%$

$0.06 \%$

$0.06 \%$

$0.58 \%$

$0.51 \%$

$0.47 \%$

$0.58 \%$

$0.16 \%$

$0.40 \%$

$0.46 \%$

$0.54 \%$

$0.52 \%$

$0.45 \%$

$0.49 \%$

$0.06 \%$

$0.36 \%$

$0.46 \%$

$0.45 \%$

$0.52 \%$

$0.42 \%$

$0.34 \%$

$-0.15 \%$

$0.50 \%$

$0.47 \%$

$0.46 \%$

$0.42 \%$

$0.53 \%$

$0.36 \%$

$0.21 \%$

$-0.26 \%$

$0.55 \%$

$0.51 \%$

$0.46 \%$

$0.53 \%$

$0.11 \%$

$0.36 \%$

$0.52 \%$

$0.52 \%$

$0.44 \%$

$0.46 \%$

$0.02 \%$

$0.46 \% \quad 0.07 \% \quad 0.07 \%$

$0.42 \%$

$0.53 \%$

$0.37 \%$

$0.22 \%$

$-0.25 \%$

$0.47 \%$

$0.46 \%$

$0.06 \% \quad 0.07 \%$

$0.53 \%$

$0.52 \%$

$0.45 \%$

$0.47 \%$ 
Hersfeld-Rotenburg.

Landkreis

Herzogtum Lauenburg.

Landkreis

Hildburghausen. Kreis

Hildesheim. Landkreis

Hochsauerlandkreis

Hochtaunuskreis

Hoexter. Kreis

Hof

Hof. Landkreis

Hohenlohekreis

Holzminden. Landkreis

HRV

HUN

IDN

IIm-Kreis

IND

Ingolstadt

IRL

ITA

Jena. krsfr. Stadt

Jerichower Land. Landkreis

JPN

Kaiserslautern. Kreisfreie

Stadt

Kaiserslautern. Landkreis

Karlsruhe. Kreisfreie Stadt

Karlsruhe. Landkreis

Kassel. Kreisfreie Stadt

Kassel. Landkreis

Kaufbeuren

Kelheim. Landkreis

Kempten (Allgaeu)

Kiel. Landeshauptstadt.

Kreisfreie Stadt

Kitzingen. Landkreis

Kleve. Kreis

Koblenz. Kreisfreie Stadt

Koeln. Kreisfreie Stadt

Konstanz. Landkreis

KOR

Krefeld. Kreisfreie Stadt

Kreisfreie Stadt Rostock.

Hansestadt

Kreisfreie Stadt Schwerin.

Landeshauptstadt

Kronach. Landkreis

\begin{tabular}{|c|c|c|c|c|c|c|c|c|}
\hline $.47 \%$ & $\%$ & $0.06 \%$ & $0.07 \%$ & $0.53 \%$ & $\%$ & $0.44 \%$ & $\%$ & $0.03 \%$ \\
\hline $44 \%$ & $0.46 \%$ & $0.06 \%$ & $0.07 \%$ & 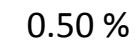 & $0.52 \%$ & $0.43 \%$ & & \\
\hline $48 \%$ & $0.46 \%$ & $0.06 \%$ & $0.06 \%$ & & $0.52 \%$ & & & \\
\hline $46 \%$ & 46 \% & $06 \%$ & $.07 \%$ & $52 \%$ & $52 \%$ & $44 \%$ & $.45 \%$ & $01 \%$ \\
\hline 6 & $\%$ & 6 & $\%$ & & & & & $6 \%$ \\
\hline 38 & $0.46 \%$ & $06 \%$ & $07 \%$ & & $53 \%$ & $\%$ & $25 \%$ & $19 \%$ \\
\hline $.45 \%$ & $0.46 \%$ & $.06 \%$ & $07 \%$ & $\%$ & $\%$ & $3 \%$ & $.43 \%$ & $2 \%$ \\
\hline $40 \%$ & $0.46 \%$ & $06 \%$ & $07 \%$ & & $52 \%$ & $\%$ & $32 \%$ & \\
\hline 6 & $0.46 \%$ & $.06 \%$ & $\%$ & & $\%$ & & $\%$ & $7 \%$ \\
\hline $.52 \%$ & $0.46 \%$ & $0.06 \%$ & $0.06 \%$ & $57 \%$ & $1 \%$ & $6 \%$ & $6 \%$ & \\
\hline $56 \%$ & $0.46 \%$ & $\%$ & $5 \%$ & & & & & $5 \%$ \\
\hline $.14 \%$ & $0.14 \%$ & $04 \%$ & $.04 \%$ & $12 \%$ & $12 \%$ & 08 \% & 08 \% & 0\% \\
\hline $.45 \%$ & $0.45 \%$ & $\%$ & $7 \%$ & & $\%$ & & & \\
\hline $01 \%$ & $.01 \%$ & $\%$ & $\%$ & $\%$ & $\%$ & $\%$ & $\%$ & $0 \%$ \\
\hline $0.52 \%$ & $0.46 \%$ & & $5 \%$ & & & $3 \%$ & & \\
\hline $01 \%$ & $-0.01 \%$ & $\%$ & $\%$ & $\%$ & $\%$ & $\%$ & $\%$ & \% \\
\hline $.68 \%$ & $0.46 \%$ & $05 \%$ & $0.05 \%$ & & $0.49 \%$ & $4 \%$ & $\%$ & $6 \%$ \\
\hline 3.64 & & & & & & & & \\
\hline $.23 \%$ & $0.23 \%$ & $0.18 \%$ & $0.18 \%$ & $\%$ & $0.42 \%$ & $\%$ & $0.37 \%$ & \% \\
\hline $47 \%$ & $0.46 \%$ & $0.0 t$ & $0.06 \%$ & & $\%$ & & $\%$ & \\
\hline $.45 \%$ & $0.46 \%$ & $.06 \%$ & $0.07 \%$ & 0.5 & $0.52 \%$ & $\%$ & $0.43 \%$ & $-0.02 \%$ \\
\hline $01 \%$ & $-0.01 \%$ & $0.22 \%$ & $-0.22 \%$ & $-0.23 \%$ & $-0.23 \%$ & $-0.22 \%$ & $-0.22 \%$ & $0.00 \%$ \\
\hline 4470 & $0.40 \%$ & .00 & 0.0710 & & & & & \\
\hline $.43 \%$ & & & & & & & & \\
\hline $.43 \%$ & $0.46 \%$ & $06 \%$ & $0.07 \%$ & $\%$ & $\%$ & & $\%$ & -0 \\
\hline $.51 \%$ & $0.46 \%$ & $06 \%$ & $0.06 \%$ & $\%$ & $\%$ & $\%$ & $\%$ & $3 \%$ \\
\hline $.42 \%$ & $6 \%$ & & $\%$ & & & & & \\
\hline $52 \%$ & $46 \%$ & $\%$ & $\%$ & & $\%$ & $\%$ & $\%$ & $\%$ \\
\hline & & & & & & & & \\
\hline 51 & & & & & & & & \\
\hline $.40 \%$ & $0.46 \%$ & $0.06 \%$ & $0.07 \%$ & $.45 \%$ & $.52 \%$ & $0.39 \%$ & $0.30 \%$ & -0 \\
\hline & & & & & & & & \\
\hline דוt & 0.4 & $06 \%$ & 0 & & & & & \\
\hline 41 & 0.4 & & $\%$ & & & & & \\
\hline $.40 \%$ & $0.46 \%$ & $0.06 \%$ & $0.07 \%$ & $\%$ & $52 \%$ & $41 \%$ & $\%$ & $4 \%$ \\
\hline & & & & & & & & \\
\hline $0.48 \%$ & $0.46 \%$ & $\%$ & $\%$ & $\%$ & $\%$ & $\%$ & $.49 \%$ & $.06 \%$ \\
\hline 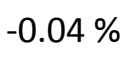 & $0.04 \%$ & & & & & $3 \%$ & & \\
\hline 0510 & $0.46 \%$ & 0060 & 0060 & $0.56 \%$ & $051 \%$ & $0.47 \%$ & $0.56 \%$ & 0120 \\
\hline 0.70 & $0.46 \%$ & $0.06 \%$ & $0.07 \%$ & $0.45 \%$ & $0.52 \%$ & $0.41 \%$ & $0.32 \%$ & \\
\hline $.41 \%$ & $\%$ & $0.06 \%$ & $0.07 \%$ & 0 & $\%$ & $\%$ & $\%$ & \\
\hline 34 & $0.40 \%$ & $0.06 \%$ & $0.06 \%$ & $0.59 \%$ & $0.51 \%$ & $\%$ & 0.61 & \\
\hline
\end{tabular}




\begin{tabular}{|c|c|c|c|c|c|c|c|c|c|}
\hline Kulmbach. Landkreis & $0.50 \%$ & $0.46 \%$ & $0.06 \%$ & $0.06 \%$ & $0.56 \%$ & $0.51 \%$ & $0.46 \%$ & $0.54 \%$ & $0.11 \%$ \\
\hline Kusel. Landkreis & $0.44 \%$ & $0.46 \%$ & $0.06 \%$ & $0.07 \%$ & $0.49 \%$ & $0.52 \%$ & $0.43 \%$ & $0.41 \%$ & $-0.05 \%$ \\
\hline Kyffhaeuserkreis & $0.47 \%$ & $0.46 \%$ & $0.06 \%$ & $0.07 \%$ & $0.53 \%$ & $0.52 \%$ & $0.46 \%$ & $0.49 \%$ & $0.04 \%$ \\
\hline Lahn-Dill-Kreis & $0.51 \%$ & $0.46 \%$ & $0.06 \%$ & $0.06 \%$ & $0.57 \%$ & $0.51 \%$ & $0.47 \%$ & $0.56 \%$ & $0.13 \%$ \\
\hline $\begin{array}{l}\text { Landau in der Pfalz. } \\
\text { Kreisfreie Stadt }\end{array}$ & $0.41 \%$ & $0.46 \%$ & $0.06 \%$ & $0.07 \%$ & $0.46 \%$ & $0.52 \%$ & $0.41 \%$ & $0.34 \%$ & $-0.13 \%$ \\
\hline $\begin{array}{l}\text { Landkreis Ludwigslust- } \\
\text { Parchim }\end{array}$ & $0.45 \%$ & $0.46 \%$ & $0.06 \%$ & $0.07 \%$ & $0.51 \%$ & $0.52 \%$ & $0.43 \%$ & $0.42 \%$ & $-0.02 \%$ \\
\hline $\begin{array}{l}\text { Landkreis Mecklenburgische } \\
\text { Seenplatte }\end{array}$ & $0.42 \%$ & $0.46 \%$ & $0.06 \%$ & $0.07 \%$ & $0.48 \%$ & $0.52 \%$ & $0.42 \%$ & $0.37 \%$ & $-0.10 \%$ \\
\hline $\begin{array}{l}\text { Landkreis } \\
\text { Nordwestmecklenburg }\end{array}$ & $0.46 \%$ & $0.46 \%$ & $0.06 \%$ & $0.07 \%$ & $0.51 \%$ & $0.52 \%$ & $0.44 \%$ & $0.44 \%$ & $-0.01 \%$ \\
\hline Landkreis Rostock & $0.39 \%$ & $0.46 \%$ & $0.07 \%$ & $0.07 \%$ & $0.45 \%$ & $0.52 \%$ & $0.40 \%$ & $0.30 \%$ & $-0.17 \%$ \\
\hline $\begin{array}{l}\text { Landkreis Vorpommern- } \\
\text { Greifswald }\end{array}$ & $0.40 \%$ & $0.46 \%$ & $0.06 \%$ & $0.07 \%$ & $0.45 \%$ & $0.52 \%$ & $0.42 \%$ & $0.33 \%$ & $-0.15 \%$ \\
\hline $\begin{array}{l}\text { Landkreis Vorpommern- } \\
\text { Ruegen }\end{array}$ & $0.39 \%$ & $0.46 \%$ & $0.07 \%$ & $0.07 \%$ & $0.45 \%$ & $0.52 \%$ & $0.41 \%$ & $0.31 \%$ & $-0.17 \%$ \\
\hline $\begin{array}{l}\text { Landsberg am Lech. } \\
\text { Landkreis }\end{array}$ & $0.46 \%$ & $0.46 \%$ & $0.06 \%$ & $0.07 \%$ & $0.52 \%$ & $0.52 \%$ & $0.44 \%$ & $0.46 \%$ & $0.01 \%$ \\
\hline Landshut & $0.47 \%$ & $0.46 \%$ & $0.06 \%$ & $0.06 \%$ & $0.53 \%$ & $0.52 \%$ & $0.45 \%$ & $0.48 \%$ & $0.04 \%$ \\
\hline Landshut. Landkreis & $0.57 \%$ & $0.46 \%$ & $0.06 \%$ & $0.06 \%$ & $0.62 \%$ & $0.51 \%$ & $0.52 \%$ & $0.69 \%$ & $0.27 \%$ \\
\hline Leer. Landkreis & $0.34 \%$ & $0.46 \%$ & $0.07 \%$ & $0.07 \%$ & $0.40 \%$ & $0.53 \%$ & $0.36 \%$ & $0.19 \%$ & $-0.29 \%$ \\
\hline Leipzig. Landkreis & $0.49 \%$ & $0.46 \%$ & $0.06 \%$ & $0.07 \%$ & $0.54 \%$ & $0.52 \%$ & $0.46 \%$ & $0.51 \%$ & $0.07 \%$ \\
\hline Leipzig. Stadt & $0.40 \%$ & $0.46 \%$ & $0.06 \%$ & $0.07 \%$ & $0.45 \%$ & $0.52 \%$ & $0.40 \%$ & $0.31 \%$ & $-0.16 \%$ \\
\hline Leverkusen. Kreisfreie Stadt & $0.56 \%$ & $0.46 \%$ & $0.05 \%$ & $0.06 \%$ & $0.61 \%$ & $0.51 \%$ & $0.51 \%$ & $0.67 \%$ & $0.26 \%$ \\
\hline Lichtenfels. Landkreis & $0.44 \%$ & $0.46 \%$ & $0.06 \%$ & $0.07 \%$ & $0.49 \%$ & $0.52 \%$ & $0.41 \%$ & $0.39 \%$ & $-0.06 \%$ \\
\hline $\begin{array}{l}\text { Limburg-Weilburg. } \\
\text { Landkreis }\end{array}$ & $0.41 \%$ & $0.46 \%$ & $0.06 \%$ & $0.07 \%$ & $0.47 \%$ & $0.52 \%$ & $0.40 \%$ & $0.33 \%$ & $-0.12 \%$ \\
\hline $\begin{array}{l}\text { Lindau (Bodensee). } \\
\text { Landkreis }\end{array}$ & $0.51 \%$ & $0.46 \%$ & $0.06 \%$ & $0.06 \%$ & $0.56 \%$ & $0.51 \%$ & $0.47 \%$ & $0.55 \%$ & $0.13 \%$ \\
\hline Lippe. Kreis & $0.48 \%$ & $0.46 \%$ & $0.06 \%$ & $0.06 \%$ & $0.54 \%$ & $0.52 \%$ & $0.45 \%$ & $0.50 \%$ & $0.06 \%$ \\
\hline Loerrach. Landkreis & $0.52 \%$ & $0.46 \%$ & $0.06 \%$ & $0.06 \%$ & $0.57 \%$ & $0.51 \%$ & $0.48 \%$ & $0.58 \%$ & $0.16 \%$ \\
\hline LTU & $0.28 \%$ & $0.28 \%$ & $0.04 \%$ & $0.04 \%$ & $0.36 \%$ & $0.36 \%$ & $0.21 \%$ & $0.21 \%$ & $0.00 \%$ \\
\hline Ludwigsburg. Landkreis & $0.51 \%$ & $0.46 \%$ & $0.06 \%$ & $0.06 \%$ & $0.57 \%$ & $0.51 \%$ & $0.46 \%$ & $0.55 \%$ & $0.14 \%$ \\
\hline $\begin{array}{l}\text { Ludwigshafen am Rhein. } \\
\text { Kreisfreie Stadt }\end{array}$ & $0.68 \%$ & $0.46 \%$ & $0.05 \%$ & $0.05 \%$ & $0.72 \%$ & $0.49 \%$ & $0.64 \%$ & $0.99 \%$ & $0.56 \%$ \\
\hline $\begin{array}{l}\text { Luebeck. Hansestadt. } \\
\text { Kreisfreie Stadt }\end{array}$ & $0.42 \%$ & $0.46 \%$ & $0.06 \%$ & $0.07 \%$ & $0.48 \%$ & $0.52 \%$ & $0.41 \%$ & $0.36 \%$ & $-0.09 \%$ \\
\hline $\begin{array}{l}\text { Luechow-Dannenberg. } \\
\text { Landkreis }\end{array}$ & $0.45 \%$ & $0.46 \%$ & $0.06 \%$ & $0.07 \%$ & $0.51 \%$ & $0.52 \%$ & $0.43 \%$ & $0.42 \%$ & $-0.02 \%$ \\
\hline Lueneburg. Landkreis & $0.42 \%$ & $0.46 \%$ & $0.06 \%$ & $0.07 \%$ & $0.47 \%$ & $0.52 \%$ & $0.42 \%$ & $0.35 \%$ & $-0.11 \%$ \\
\hline LUX & $2.33 \%$ & $2.33 \%$ & $-0.71 \%$ & $-0.71 \%$ & $1.31 \%$ & $1.31 \%$ & $1.47 \%$ & $1.47 \%$ & $0.00 \%$ \\
\hline LVA & $0.09 \%$ & $0.09 \%$ & $-0.11 \%$ & $-0.11 \%$ & $-0.01 \%$ & $-0.01 \%$ & $-0.01 \%$ & $-0.01 \%$ & $0.00 \%$ \\
\hline $\begin{array}{l}\text { Maerkisch-Oderland. } \\
\text { Landkreis }\end{array}$ & $0.40 \%$ & $0.46 \%$ & $0.07 \%$ & $0.07 \%$ & $0.46 \%$ & $0.52 \%$ & $0.41 \%$ & $0.32 \%$ & $-0.15 \%$ \\
\hline Maerkischer Kreis & $0.58 \%$ & $0.46 \%$ & $0.05 \%$ & $0.06 \%$ & $0.63 \%$ & $0.50 \%$ & $0.52 \%$ & $0.71 \%$ & $0.30 \%$ \\
\hline Magdeburg. Kreisfreie Stadt & $0.41 \%$ & $0.46 \%$ & $0.06 \%$ & $0.07 \%$ & $0.46 \%$ & $0.52 \%$ & $0.42 \%$ & $0.35 \%$ & $-0.12 \%$ \\
\hline Main-Kinzig-Kreis & $0.47 \%$ & $0.46 \%$ & $0.06 \%$ & $0.06 \%$ & $0.52 \%$ & $0.52 \%$ & $0.43 \%$ & $0.45 \%$ & $0.02 \%$ \\
\hline Main-Spessart. Landkreis & $0.58 \%$ & $0.46 \%$ & $0.06 \%$ & $0.06 \%$ & $0.63 \%$ & $0.50 \%$ & $0.53 \%$ & $0.72 \%$ & $0.30 \%$ \\
\hline Main-Tauber-Kreis & $0.50 \%$ & $0.46 \%$ & $0.06 \%$ & $0.06 \%$ & $0.56 \%$ & $0.51 \%$ & $0.47 \%$ & $0.54 \%$ & $0.11 \%$ \\
\hline
\end{tabular}




\begin{tabular}{|c|c|c|c|c|c|c|c|c|c|}
\hline Main-Taunus-Kreis & $0.31 \%$ & $0.46 \%$ & $0.06 \%$ & $0.07 \%$ & $0.36 \%$ & $0.53 \%$ & $0.31 \%$ & $0.08 \%$ & $-0.39 \%$ \\
\hline Mainz-Bingen. Landkreis & $0.52 \%$ & $0.46 \%$ & $0.06 \%$ & $0.06 \%$ & $0.57 \%$ & $0.51 \%$ & $0.47 \%$ & $0.57 \%$ & $0.15 \%$ \\
\hline Mainz. Kreisfreie Stadt & $0.38 \%$ & $0.46 \%$ & $0.06 \%$ & $0.07 \%$ & $0.43 \%$ & $0.52 \%$ & $0.39 \%$ & $0.27 \%$ & $-0.20 \%$ \\
\hline Mannheim. & & & & & & & & & \\
\hline $\begin{array}{l}\text { Universitaetsstadt. } \\
\text { Kreisfreie Stadt }\end{array}$ & $0.49 \%$ & $0.46 \%$ & $0.06 \%$ & $0.06 \%$ & $0.54 \%$ & $0.52 \%$ & $0.44 \%$ & $0.50 \%$ & $0.08 \%$ \\
\hline $\begin{array}{l}\text { Mansfeld-Suedharz. } \\
\text { Landkreis }\end{array}$ & $0.45 \%$ & $0.46 \%$ & $0.06 \%$ & $0.07 \%$ & $0.50 \%$ & $0.52 \%$ & $0.43 \%$ & $0.42 \%$ & $-0.03 \%$ \\
\hline $\begin{array}{l}\text { Marburg-Biedenkopf. } \\
\text { Landkreis }\end{array}$ & $0.52 \%$ & $0.46 \%$ & $0.06 \%$ & $0.06 \%$ & $0.58 \%$ & $0.51 \%$ & $0.49 \%$ & $0.60 \%$ & $0.17 \%$ \\
\hline Mayen-Koblenz. Landkreis & $0.49 \%$ & $0.46 \%$ & $0.06 \%$ & $0.06 \%$ & $0.55 \%$ & $0.52 \%$ & $0.46 \%$ & $0.52 \%$ & $0.09 \%$ \\
\hline Meissen. Landkreis & $0.50 \%$ & $0.46 \%$ & $0.06 \%$ & $0.06 \%$ & $0.55 \%$ & $0.51 \%$ & $0.47 \%$ & $0.54 \%$ & $0.11 \%$ \\
\hline Memmingen & $0.50 \%$ & $0.46 \%$ & $0.06 \%$ & $0.06 \%$ & $0.56 \%$ & $0.51 \%$ & $0.46 \%$ & $0.54 \%$ & $0.11 \%$ \\
\hline Merzig-Wadern. Landkreis & $0.42 \%$ & $0.46 \%$ & $0.06 \%$ & $0.07 \%$ & $0.48 \%$ & $0.52 \%$ & $0.41 \%$ & $0.36 \%$ & $-0.09 \%$ \\
\hline Mettmann. Kreis & $0.46 \%$ & $0.46 \%$ & $0.06 \%$ & $0.06 \%$ & $0.52 \%$ & $0.52 \%$ & $0.42 \%$ & $0.43 \%$ & $0.01 \%$ \\
\hline MEX & $-0.05 \%$ & $-0.05 \%$ & $-0.35 \%$ & $-0.35 \%$ & $-0.41 \%$ & $-0.41 \%$ & $-0.39 \%$ & $-0.39 \%$ & $0.00 \%$ \\
\hline Miesbach. Landkreis & $0.42 \%$ & $0.46 \%$ & $0.06 \%$ & $0.07 \%$ & $0.48 \%$ & $0.52 \%$ & $0.41 \%$ & $0.35 \%$ & $-0.10 \%$ \\
\hline Miltenberg. Landkreis & $0.51 \%$ & $0.46 \%$ & $0.06 \%$ & $0.06 \%$ & $0.57 \%$ & $0.51 \%$ & $0.47 \%$ & $0.56 \%$ & $0.14 \%$ \\
\hline Minden-Luebbecke. Kreis & $0.48 \%$ & $0.46 \%$ & $0.06 \%$ & $0.06 \%$ & $0.53 \%$ & $0.52 \%$ & $0.44 \%$ & $0.48 \%$ & $0.05 \%$ \\
\hline Mittelsachsen. Landkreis & $0.49 \%$ & $0.46 \%$ & $0.06 \%$ & $0.06 \%$ & $0.54 \%$ & $0.52 \%$ & $0.46 \%$ & $0.51 \%$ & $0.08 \%$ \\
\hline MLT & $0.53 \%$ & $0.53 \%$ & $-0.23 \%$ & $-0.23 \%$ & $0.36 \%$ & $0.36 \%$ & $0.37 \%$ & $0.37 \%$ & $0.00 \%$ \\
\hline $\begin{array}{l}\text { Moenchengladbach. } \\
\text { Kreisfreie Stadt }\end{array}$ & $0.42 \%$ & 0.46 & $0.06 \%$ & $0.07 \%$ & 0. & $0.52 \%$ & $0.41 \%$ & $0.36 \%$ & -0 \\
\hline Muehldorf a.Inn. Landkreis & $0.51 \%$ & $0.46 \%$ & $0.06 \%$ & $0.06 \%$ & $0.57 \%$ & $0.51 \%$ & $0.47 \%$ & $0.56 \%$ & $0.14 \%$ \\
\hline $\begin{array}{l}\text { Muelheim an der Ruhr. } \\
\text { Kreisfreie Stadt }\end{array}$ & $0.43 \%$ & $0.46 \%$ & $0.06 \%$ & $0.07 \%$ & $0.4 \varepsilon$ & $0.52 \%$ & $0.39 \%$ & $0.35 \%$ & -0 . \\
\hline $\begin{array}{l}\text { Muenchen. } \\
\text { Landeshauptstadt }\end{array}$ & $0.42 \%$ & $0.46 \%$ & $0.06 \%$ & $0.07 \%$ & $0.47 \%$ & $0.52 \%$ & $0.40 \%$ & $0.34 \%$ & $-0.11 \%$ \\
\hline Muenchen. Landkreis & $0.36 \%$ & $0.46 \%$ & $0.06 \%$ & $0.07 \%$ & $0.42 \%$ & $0.53 \%$ & $0.34 \%$ & $0.19 \%$ & $-0.25 \%$ \\
\hline Muenster. Kreisfreie Stadt & $0.38 \%$ & $0.46 \%$ & $0.06 \%$ & $0.07 \%$ & $0.43 \%$ & $0.52 \%$ & $0.40 \%$ & $0.28 \%$ & $-0.20 \%$ \\
\hline Neckar-Odenwald-Kreis & $0.49 \%$ & $0.46 \%$ & $0.06 \%$ & $0.06 \%$ & $0.55 \%$ & $0.52 \%$ & $0.46 \%$ & $0.52 \%$ & $0.08 \%$ \\
\hline Neu-Ulm. Landkreis & $0.52 \%$ & $0.46 \%$ & $0.06 \%$ & $0.06 \%$ & $0.57 \%$ & $0.51 \%$ & $0.47 \%$ & $0.57 \%$ & $0.15 \%$ \\
\hline $\begin{array}{l}\text { Neuburg-Schrobenhausen. } \\
\text { Landkreis }\end{array}$ & $0.50 \%$ & $0.46 \%$ & $0.06 \%$ & $0.07 \%$ & $0.55 \%$ & $0.52 \%$ & $0.46 \%$ & $0.53 \%$ & $0.09 \%$ \\
\hline $\begin{array}{l}\text { Neumarkt i.d.OPf.. } \\
\text { Landkreis }\end{array}$ & $.48 \%$ & $0.46 \%$ & $0.06 \%$ & $0.07 \%$ & $0.54 \%$ & $0.52 \%$ & $0.45 \%$ & $0.49 \%$ & $0.06 \%$ \\
\hline $\begin{array}{l}\text { Neumuenster. Kreisfreie } \\
\text { Stadt }\end{array}$ & $0.42 \%$ & $0.46 \%$ & 0.0 & $07 \%$ & $\%$ & $0.52 \%$ & $0.41 \%$ & $0.36 \%$ & -0 . \\
\hline Neunkirchen. Landkreis & $0.47 \%$ & $0.46 \%$ & $0.06 \%$ & $0.07 \%$ & $0.53 \%$ & $0.52 \%$ & $0.45 \%$ & $0.47 \%$ & $0.03 \%$ \\
\hline $\begin{array}{l}\text { Neustadt a.d.Aisch-Bad } \\
\text { Windsheim. Landkreis }\end{array}$ & $0.46 \%$ & $0.46 \%$ & $0.06 \%$ & $0.07 \%$ & $0.51 \%$ & $0.52 \%$ & $0.43 \%$ & $0.43 \%$ & -0. \\
\hline $\begin{array}{l}\text { Neustadt a.d.Waldnaab. } \\
\text { Landkreis } \\
\text { Neustadt an der }\end{array}$ & $0.54 \%$ & $0.46 \%$ & $0.06 \%$ & $0.06 \%$ & $0.59 \%$ & $0.51 \%$ & $0.49 \%$ & $0.62 \%$ & $0.19 \%$ \\
\hline $\begin{array}{l}\text { Weinstrasse. Kreisfreie } \\
\text { Stadt }\end{array}$ & $0.38 \%$ & $0.46 \%$ & $0.07 \%$ & $0.07 \%$ & $0.44 \%$ & $0.52 \%$ & $0.40 \%$ & $0.29 \%$ & $-0.20 \%$ \\
\hline Neuwied. Landkreis & $0.50 \%$ & $0.46 \%$ & $0.06 \%$ & $0.06 \%$ & $0.55 \%$ & $0.51 \%$ & $0.46 \%$ & $0.54 \%$ & $0.11 \%$ \\
\hline Nienburg (Weser). Landkreis & $0.46 \%$ & $0.46 \%$ & $0.06 \%$ & $0.07 \%$ & $0.51 \%$ & $0.52 \%$ & $0.43 \%$ & $0.44 \%$ & $-0.01 \%$ \\
\hline NLD & $0.75 \%$ & $0.76 \%$ & $-0.49 \%$ & $-0.49 \%$ & $0.29 \%$ & $0.29 \%$ & $0.22 \%$ & $0.22 \%$ & $0.00 \%$ \\
\hline NOR & $-0.06 \%$ & $-0.06 \%$ & $-0.17 \%$ & $-0.17 \%$ & $-0.20 \%$ & $-0.20 \%$ & $-0.19 \%$ & $-0.19 \%$ & $0.00 \%$ \\
\hline
\end{tabular}




\begin{tabular}{|c|c|c|c|c|c|c|c|c|c|}
\hline Nordfriesland. Landkreis & $0.41 \%$ & $0.46 \%$ & $0.06 \%$ & $0.07 \%$ & $0.47 \%$ & $0.52 \%$ & $0.41 \%$ & $0.33 \%$ & $-0.13 \%$ \\
\hline Nordhausen. Kreis & $0.47 \%$ & $0.46 \%$ & $0.06 \%$ & $0.07 \%$ & $0.53 \%$ & $0.52 \%$ & $0.46 \%$ & $0.49 \%$ & $0.04 \%$ \\
\hline Nordsachsen. Landkreis & $.44 \%$ & $0.46 \%$ & $0.06 \%$ & $0.07 \%$ & $0.49 \%$ & $0.52 \%$ & $0.42 \%$ & $0.39 \%$ & $-0.06 \%$ \\
\hline Northeim. Landkreis & $.49 \%$ & $0.46 \%$ & $0.06 \%$ & $0.06 \%$ & $0.54 \%$ & $0.52 \%$ & $0.46 \%$ & $0.51 \%$ & $0.08 \%$ \\
\hline Nuernberg & $.42 \%$ & $0.46 \%$ & $0.06 \%$ & $0.07 \%$ & $0.48 \%$ & $0.52 \%$ & $0.40 \%$ & $0.34 \%$ & $-0.10 \%$ \\
\hline $\begin{array}{l}\text { Nuernberger Land. } \\
\text { Landkreis }\end{array}$ & $0.50 \%$ & $0.46 \%$ & $0.06 \%$ & $0.06 \%$ & $0.55 \%$ & $0.51 \%$ & $0.46 \%$ & $0.53 \%$ & $0.11 \%$ \\
\hline Oberallgaeu. Landkreis & $0.47 \%$ & $0.46 \%$ & $0.06 \%$ & $0.07 \%$ & $0.52 \%$ & $0.52 \%$ & $0.43 \%$ & $0.45 \%$ & $0.02 \%$ \\
\hline Oberbergischer Kreis & $0.53 \%$ & $0.46 \%$ & $0.06 \%$ & $0.06 \%$ & $0.58 \%$ & $0.51 \%$ & $0.48 \%$ & $0.60 \%$ & $0.18 \%$ \\
\hline $\begin{array}{l}\text { Oberhausen. Kreisfreie } \\
\text { Stadt }\end{array}$ & $0.47 \%$ & $0.46 \%$ & $0.06 \%$ & $0.06 \%$ & $0.53 \%$ & $0.52 \%$ & $0.44 \%$ & $0.47 \%$ & $0.04 \%$ \\
\hline Oberhavel. Landkreis & $0.44 \%$ & $0.46 \%$ & $0.06 \%$ & $0.07 \%$ & $0.50 \%$ & $0.52 \%$ & $0.42 \%$ & $0.40 \%$ & $-0.04 \%$ \\
\hline $\begin{array}{l}\text { reewald-Lausitz. } \\
\text { eis }\end{array}$ & $.47 \%$ & $0.46 \%$ & $0.06 \%$ & $0.07 \%$ & $0.53 \%$ & $0.52 \%$ & $0.45 \%$ & $0.47 \%$ & $0.03 \%$ \\
\hline kreis & $0.50 \%$ & $0.46 \%$ & $0.06 \%$ & $0.06 \%$ & $0.56 \%$ & $0.51 \%$ & $0.46 \%$ & $0.54 \%$ & $0.11 \%$ \\
\hline Oder-Spree. Landkreis & $0.47 \%$ & $0.46 \%$ & $0.06 \%$ & $0.07 \%$ & $0.52 \%$ & $0.52 \%$ & $0.45 \%$ & $0.46 \%$ & $0.02 \%$ \\
\hline $\begin{array}{l}\text { Offer } \\
\text { Kreis }\end{array}$ & 40 & $\%$ & 0 & $\%$ & 0. & 0. & $\%$ & $\%$ & $\%$ \\
\hline Offenbach. Landkreis & 39 \% & $.46 \%$ & $.06 \%$ & $0.07 \%$ & $0.45 \%$ & $0.53 \%$ & $0.37 \%$ & $0.26 \%$ & $-0.18 \%$ \\
\hline $\begin{array}{l}\text { Olde } \\
\text { Kreis }\end{array}$ & $\%$ & $0.46 \%$ & $6 \%$ & $0.07 \%$ & $0.44 \%$ & $\%$ & $\%$ & $\%$ & $\%$ \\
\hline Oldenburg. L & $.43 \%$ & $0.46 \%$ & $0.06 \%$ & $0.07 \%$ & $0.49 \%$ & $0.52 \%$ & $0.41 \%$ & $0.36 \%$ & $-0.08 \%$ \\
\hline Olpe. Kreis & $0.59 \%$ & $0.46 \%$ & $0.05 \%$ & $0.06 \%$ & $0.63 \%$ & $0.50 \%$ & $0.54 \%$ & $0.74 \%$ & $0.32 \%$ \\
\hline Ortenaukreis & $0.50 \%$ & $0.46 \%$ & $0.06 \%$ & $0.06 \%$ & $0.55 \%$ & $0.52 \%$ & $0.46 \%$ & $0.52 \%$ & $0.10 \%$ \\
\hline Osnabrueck. Krei & $0.42 \%$ & $0.46 \%$ & $0.06 \%$ & $0.07 \%$ & $0.48 \%$ & $0.52 \%$ & $0.41 \%$ & $0.35 \%$ & $-0.10 \%$ \\
\hline Osnabruec & $0.49 \%$ & $0.46 \%$ & $0.06 \%$ & $0.06 \%$ & $0.55 \%$ & $0.52 \%$ & $0.45 \%$ & $0.51 \%$ & $0.09 \%$ \\
\hline Ostalbkreis & $0.56 \%$ & $0.46 \%$ & $0.06 \%$ & $0.06 \%$ & $0.61 \%$ & $0.51 \%$ & $0.52 \%$ & $0.69 \%$ & $0.27 \%$ \\
\hline Osta & $0.50 \%$ & $0.46 \%$ & $0.06 \%$ & $0.06 \%$ & $0.55 \%$ & $0.51 \%$ & $0.46 \%$ & $0.53 \%$ & $0.11 \%$ \\
\hline Osterholz. Landkreis & $0.40 \%$ & $0.46 \%$ & $0.06 \%$ & $0.07 \%$ & $0.45 \%$ & $0.52 \%$ & $0.40 \%$ & $0.31 \%$ & $-0.16 \%$ \\
\hline $\begin{array}{l}\text { Oste } \\
\text { Lano }\end{array}$ & $\%$ & $\%$ & $\%$ & $\%$ & $\%$ & $\%$ & $\%$ & $\%$ & $\%$ \\
\hline dkreis & $0.39 \%$ & $0.46 \%$ & $0.06 \%$ & $0.07 \%$ & $0.45 \%$ & $0.52 \%$ & $0.40 \%$ & $0.31 \%$ & $-0.17 \%$ \\
\hline uppin. & $0.45 \%$ & $\%$ & $\%$ & $\%$ & $\%$ & $\%$ & $\%$ & $\%$ & $\%$ \\
\hline orn. Kreis & $0.46 \%$ & $0.46 \%$ & $0.06 \%$ & $0.07 \%$ & $0.51 \%$ & $0.52 \%$ & $0.43 \%$ & $0.44 \%$ & $-0.01 \%$ \\
\hline Passau & $0.46 \%$ & $0.46 \%$ & $0.06 \%$ & $0.07 \%$ & $0.51 \%$ & $0.52 \%$ & $0.43 \%$ & $0.43 \%$ & $-0.01 \%$ \\
\hline Passau. L & $0.50 \%$ & $0.46 \%$ & $0.06 \%$ & $0.06 \%$ & $0.55 \%$ & $0.52 \%$ & $0.46 \%$ & $0.52 \%$ & $0.09 \%$ \\
\hline Peine. Landkreis & $0.48 \%$ & $0.46 \%$ & $0.06 \%$ & $0.06 \%$ & $0.54 \%$ & $0.52 \%$ & $0.45 \%$ & $0.49 \%$ & $0.05 \%$ \\
\hline $\begin{array}{l}\text { Pfaffenhofen a.c } \\
\text { Landkreis }\end{array}$ & $0.57 \%$ & $0.46 \%$ & $\%$ & $0.06 \%$ & $0.62 \%$ & $0.51 \%$ & $0.52 \%$ & $9 \%$ & $0.28 \%$ \\
\hline Pforzheim. Kreisfreie Stadt & $0.49 \%$ & $0.46 \%$ & $0.06 \%$ & $0.06 \%$ & $0.55 \%$ & $0.52 \%$ & $0.45 \%$ & $0.51 \%$ & $0.08 \%$ \\
\hline Pinneberg. Landkreis & $0.46 \%$ & $0.46 \%$ & $0.06 \%$ & $0.07 \%$ & $0.51 \%$ & $0.52 \%$ & $0.43 \%$ & $0.43 \%$ & $-0.01 \%$ \\
\hline Pirmasens. Kreisfreie Stadt & $0.45 \%$ & $0.46 \%$ & $0.06 \%$ & $0.07 \%$ & $0.51 \%$ & $0.52 \%$ & $0.43 \%$ & $0.43 \%$ & $-0.02 \%$ \\
\hline Ploen. Landkreis & $0.43 \%$ & $0.46 \%$ & $0.06 \%$ & $0.07 \%$ & $0.49 \%$ & $0.52 \%$ & $0.42 \%$ & $0.39 \%$ & $-0.06 \%$ \\
\hline POL & $0.12 \%$ & $0.12 \%$ & $-0.07 \%$ & $-0.07 \%$ & $0.06 \%$ & $0.06 \%$ & $0.06 \%$ & $0.06 \%$ & $0.00 \%$ \\
\hline $\begin{array}{l}\text { Potsdam-Mittelmark. } \\
\text { Landkreis }\end{array}$ & 0 & 0.46 & $07 \%$ & $0.07 \%$ & $0.45 \%$ & $0.52 \%$ & $0.39 \%$ & $0.30 \%$ & $-0.17 \%$ \\
\hline Potsdam. Kreisfreie Stadt & $0.37 \%$ & $0.46 \%$ & $0.07 \%$ & $0.07 \%$ & $0.42 \%$ & $0.52 \%$ & $0.41 \%$ & $0.28 \%$ & $-0.22 \%$ \\
\hline Prignitz. Landkreis & $0.45 \%$ & $0.46 \%$ & $0.06 \%$ & $0.07 \%$ & $0.51 \%$ & $0.52 \%$ & $0.43 \%$ & $0.43 \%$ & $-0.02 \%$ \\
\hline
\end{tabular}




\begin{tabular}{|c|c|c|c|c|c|c|c|c|c|}
\hline PRT & $0.13 \%$ & $0.13 \%$ & $0.00 \%$ & $0.00 \%$ & $0.16 \%$ & $0.16 \%$ & $0.11 \%$ & $0.11 \%$ & $0.00 \%$ \\
\hline Rastatt. Landkreis & $0.60 \%$ & $0.46 \%$ & $0.05 \%$ & $0.06 \%$ & $0.65 \%$ & $0.50 \%$ & $0.55 \%$ & $0.78 \%$ & $0.36 \%$ \\
\hline Ravensburg. Landkreis & $0.47 \%$ & $0.46 \%$ & $0.06 \%$ & $0.06 \%$ & $0.52 \%$ & $0.52 \%$ & $0.43 \%$ & $0.45 \%$ & $0.02 \%$ \\
\hline Recklinghausen. Kreis & $0.48 \%$ & $0.46 \%$ & $0.06 \%$ & $0.06 \%$ & $0.54 \%$ & $0.52 \%$ & $0.45 \%$ & $0.49 \%$ & $0.06 \%$ \\
\hline Regen. Landkreis & $0.48 \%$ & $0.46 \%$ & $0.06 \%$ & $0.07 \%$ & $0.53 \%$ & $0.52 \%$ & $0.45 \%$ & $0.49 \%$ & $0.05 \%$ \\
\hline Regensburg & $0.57 \%$ & $0.46 \%$ & $0.05 \%$ & $0.06 \%$ & $0.62 \%$ & $0.51 \%$ & $0.52 \%$ & $0.70 \%$ & $0.28 \%$ \\
\hline Regensburg. Landkreis & $0.46 \%$ & $0.46 \%$ & $0.06 \%$ & $0.07 \%$ & $0.52 \%$ & $0.52 \%$ & $0.43 \%$ & $0.44 \%$ & $0.01 \%$ \\
\hline Region Hannover. Landkreis & $0.43 \%$ & $0.46 \%$ & $0.06 \%$ & $0.07 \%$ & $0.48 \%$ & $0.52 \%$ & $0.41 \%$ & $0.36 \%$ & $-0.08 \%$ \\
\hline Rems-Murr-Kreis & $0.50 \%$ & $0.46 \%$ & $0.06 \%$ & $0.06 \%$ & $0.55 \%$ & $0.52 \%$ & $0.46 \%$ & $0.52 \%$ & $0.10 \%$ \\
\hline Remscheid. Kreisfreie Stadt & $0.54 \%$ & $0.46 \%$ & $0.06 \%$ & $0.06 \%$ & $0.59 \%$ & $0.51 \%$ & $0.49 \%$ & $0.63 \%$ & $0.21 \%$ \\
\hline $\begin{array}{l}\text { Rendsburg-Eckernfoerde. } \\
\text { Landkreis }\end{array}$ & $0.37 \%$ & $0.46 \%$ & $0.07 \%$ & $0.07 \%$ & $0.43 \%$ & $0.52 \%$ & $0.38 \%$ & $0.25 \%$ & $\%$ \\
\hline Reutlingen. Landkreis & $0.51 \%$ & $0.46 \%$ & $0.06 \%$ & $0.06 \%$ & $0.56 \%$ & $0.51 \%$ & $0.47 \%$ & $0.55 \%$ & $0.13 \%$ \\
\hline Rhein-Erft-Kreis & $0.46 \%$ & $0.46 \%$ & $0.06 \%$ & $0.06 \%$ & $0.52 \%$ & $0.52 \%$ & $0.43 \%$ & $0.44 \%$ & $0.01 \%$ \\
\hline Rhein-Hunsrueck-Kreis & $0.46 \%$ & $0.46 \%$ & $0.06 \%$ & $0.07 \%$ & $0.52 \%$ & $0.52 \%$ & $0.44 \%$ & $0.45 \%$ & $0.01 \%$ \\
\hline Rhein-Kreis Neuss & $0.46 \%$ & $0.46 \%$ & $0.06 \%$ & $0.06 \%$ & $0.52 \%$ & $0.52 \%$ & $0.42 \%$ & $0.43 \%$ & $0.00 \%$ \\
\hline Rhein-Lahn-Kreis & $0.47 \%$ & $0.46 \%$ & $0.06 \%$ & $0.07 \%$ & $0.52 \%$ & $0.52 \%$ & $0.45 \%$ & $0.47 \%$ & $0.03 \%$ \\
\hline r-Kreis & $0.42 \%$ & $0.46 \%$ & $0.06 \%$ & $0.07 \%$ & $0.48 \%$ & $0.52 \%$ & $0.39 \%$ & $0.34 \%$ & $-0.10 \%$ \\
\hline Rhein-Pfalz-Kreis & $0.40 \%$ & $0.46 \%$ & $0.07 \%$ & $0.07 \%$ & $0.46 \%$ & $0.53 \%$ & $0.39 \%$ & $0.30 \%$ & $-0.15 \%$ \\
\hline Sieg-Kreis & $0.41 \%$ & $0.46 \%$ & $0.06 \%$ & $0.07 \%$ & $0.47 \%$ & $0.52 \%$ & $0.40 \%$ & $0.33 \%$ & $-0.12 \%$ \\
\hline Rheingau-Taunus-Kreis & $0.44 \%$ & $0.46 \%$ & $0.06 \%$ & $0.07 \%$ & $0.49 \%$ & $0.52 \%$ & $0.41 \%$ & $0.39 \%$ & $-0.05 \%$ \\
\hline Rheinisch-Bergischer Kreis & $0.41 \%$ & $0.46 \%$ & $0.06 \%$ & $0.07 \%$ & $0.47 \%$ & $0.52 \%$ & $0.41 \%$ & $0.34 \%$ & $-0.11 \%$ \\
\hline Rhoen-Grabf & $0.49 \%$ & $0.46 \%$ & $0.06 \%$ & $0.06 \%$ & $0.55 \%$ & $0.51 \%$ & $0.46 \%$ & $0.52 \%$ & $0.09 \%$ \\
\hline Rosenheim & $0.41 \%$ & $0.46 \%$ & $0.06 \%$ & $0.07 \%$ & $0.47 \%$ & $0.52 \%$ & $0.41 \%$ & $0.35 \%$ & $-0.12 \%$ \\
\hline n. Landk & $0.45 \%$ & $0.46 \%$ & $0.06 \%$ & $0.07 \%$ & $0.51 \%$ & $0.52 \%$ & $0.43 \%$ & $0.42 \%$ & $-0.01 \%$ \\
\hline $\begin{array}{l}\text { urg (Wuemme). } \\
\text { eis }\end{array}$ & $\%$ & 0 & $0.07 \%$ & $\%$ & $\%$ & $\%$ & $\%$ & $\%$ & $\%$ \\
\hline Roth. Lal & $0.45 \%$ & $0.46 \%$ & $0.06 \%$ & $0.07 \%$ & $0.51 \%$ & $0.52 \%$ & & $0.43 \%$ & \\
\hline Rottal-Inn. Landkreis & $0.46 \%$ & $0.46 \%$ & $0.06 \%$ & $0.07 \%$ & $0.52 \%$ & $0.52 \%$ & $0.43 \%$ & $0.44 \%$ & $0.00 \%$ \\
\hline Rottw & $0.56 \%$ & $0.46 \%$ & $0.06 \%$ & $0.06 \%$ & $0.61 \%$ & $0.51 \%$ & $0.51 \%$ & $0.67 \%$ & $0.25 \%$ \\
\hline ROU & $0.11 \%$ & $0.11 \%$ & $-0.03 \%$ & $-0.03 \%$ & $0.09 \%$ & $0.09 \%$ & $0.08 \%$ & $0.08 \%$ & $0.00 \%$ \\
\hline ROW & $0.00 \%$ & $0.00 \%$ & $-0.16 \%$ & $-0.17 \%$ & $-0.19 \%$ & $-0.19 \%$ & $-0.17 \%$ & $-0.17 \%$ & $0.00 \%$ \\
\hline RUS & $-0.02 \%$ & $-0.02 \%$ & $-0.14 \%$ & $-0.15 \%$ & $-0.16 \%$ & $-0.16 \%$ & $-0.16 \%$ & $-0.16 \%$ & $0.00 \%$ \\
\hline Saale-Holzland-Kreis & $0.46 \%$ & $0.46 \%$ & $0.06 \%$ & $0.07 \%$ & $0.52 \%$ & $0.52 \%$ & $0.44 \%$ & $0.45 \%$ & $0.01 \%$ \\
\hline Saale-Orla-Kreis & $0.53 \%$ & $0.46 \%$ & $0.06 \%$ & $0.06 \%$ & $0.58 \%$ & $0.51 \%$ & $0.49 \%$ & $0.60 \%$ & $0.17 \%$ \\
\hline Saalekreis & $0.55 \%$ & $0.46 \%$ & $0.06 \%$ & $0.06 \%$ & $0.61 \%$ & $0.51 \%$ & $0.51 \%$ & $0.66 \%$ & $0.24 \%$ \\
\hline Saalfeld-Rudolstadt. Kreis & $0.52 \%$ & $0.46 \%$ & $0.06 \%$ & $0.06 \%$ & $0.57 \%$ & $0.51 \%$ & $0.49 \%$ & $0.59 \%$ & $0.16 \%$ \\
\hline $\begin{array}{l}\text { Saarbruecken. } \\
\text { Regionalverband }\end{array}$ & $0.47 \%$ & $0.46 \%$ & $0.06 \%$ & $0.06 \%$ & $0.52 \%$ & $0.52 \%$ & $0.44 \%$ & $0.45 \%$ & $0.02 \%$ \\
\hline Saarlouis. Landkreis & $0.53 \%$ & $0.46 \%$ & $0.06 \%$ & $0.06 \%$ & $0.58 \%$ & $0.51 \%$ & $0.48 \%$ & $0.60 \%$ & $0.18 \%$ \\
\hline Saarpfalz-Kreis & $0.54 \%$ & $0.46 \%$ & $0.06 \%$ & $0.06 \%$ & $0.60 \%$ & $0.51 \%$ & $0.50 \%$ & $0.64 \%$ & $0.22 \%$ \\
\hline $\begin{array}{l}\text { Saechsische Schweiz- } \\
\text { Osterzgebirge. Landkre }\end{array}$ & $0.46 \%$ & $0.46 \%$ & $0.06 \%$ & $0.07 \%$ & 0. & $0.52 \%$ & $0.45 \%$ & $0.46 \%$ & 0 \\
\hline Salzgitter. Kreisfreie Stadt & $0.63 \%$ & $0.46 \%$ & $0.05 \%$ & $0.06 \%$ & $0.68 \%$ & $0.50 \%$ & $0.58 \%$ & $0.86 \%$ & $0.44 \%$ \\
\hline Salzlandkreis & $0.50 \%$ & $0.46 \%$ & $0.06 \%$ & $0.06 \%$ & $0.55 \%$ & $0.51 \%$ & $0.47 \%$ & $0.54 \%$ & $0.10 \%$ \\
\hline Schaumburg. Landkreis & $0.46 \%$ & $0.46 \%$ & $0.06 \%$ & $0.07 \%$ & $0.51 \%$ & $0.52 \%$ & $0.44 \%$ & $0.44 \%$ & $0.00 \%$ \\
\hline $\begin{array}{l}\text { Schleswig-Flensburg. } \\
\text { Landkreis }\end{array}$ & $0.39 \%$ & $0.46 \%$ & $0.07 \%$ & $0.07 \%$ & $0.45 \%$ & $0.52 \%$ & $0.40 \%$ & $0.30 \%$ & $-U$. \\
\hline
\end{tabular}


Schmalkalden-Meiningen.

Kreis

Schwabach

Schwaebisch Hall. Landkreis

Schwalm-Eder-Kreis

Schwandorf. Landkreis

Schwarzwald-Baar-Kreis

Schweinfurt

Schweinfurt. Landkreis

Segeberg. Landkreis

Siegen-Wittgenstein. Kreis

Sigmaringen. Landkreis

Soemmerda. Kreis

Soest. Kreis

Solingen. Kreisfreie Stadt

Sonneberg. Kreis

Speyer. Kreisfreie Stadt

Spree-Neisse. Landkreis

St. Wendel. Landkreis

Stade. Landkreis

Staedteregion Aachen

(einschl. Stadt Aachen)

Starnberg. Landkreis

Steinburg. Landkreis

Steinfurt. Kreis

Stendal. Landkreis

Stormarn. Landkreis

Straubing

Straubing-Bogen. Landkreis

Stuttgart. Landeshauptstadt

Suedliche Weinstrasse.

Landkreis

Suedwestpfalz. Landkreis

Suhl. krsfr. Stadt

SVK

SVN

SWE

Teltow-Flaeming. Landkreis

Tirschenreuth. Landkreis

Traunstein. Landkreis

Trier-Saarburg. Landkreis

Trier. Kreisfreie Stadt

Tuebingen. Landkreis

TUR

Tuttlingen. Landkreis

TWN

Uckermark. Landkreis

Uelzen. Landkreis
$0.52 \%$

$0.47 \%$

$0.51 \%$

$0.45 \%$

$0.48 \%$

$0.52 \%$

$0.63 \%$

$0.47 \%$

$0.44 \%$

$0.54 \%$

$0.51 \%$

$0.49 \%$

$0.52 \%$

$0.49 \%$

$0.57 \%$

$0.48 \%$

$0.64 \%$

$0.51 \%$

$0.43 \%$

$0.46 \%$

$0.45 \%$

$0.48 \%$

$0.46 \%$

$0.43 \%$

$0.45 \%$

$0.43 \%$

$0.48 \%$

$0.46 \%$

$0.46 \%$

$0.42 \%$

$0.41 \%$

$0.14 \%$

$0.11 \%$

$0.33 \%$

$0.49 \%$

$0.52 \%$

$0.53 \%$

$0.44 \%$

$0.44 \%$

$0.47 \%$

$-0.02 \%$

$0.62 \%$

$-0.06 \%$

$0.49 \%$

$0.40 \%$
$0.46 \%$

$0.46 \%$

$0.46 \%$

$0.46 \%$

$0.46 \%$

$0.46 \%$

$0.46 \%$

$0.46 \%$

$0.46 \%$

$0.46 \%$

$0.46 \%$

$0.46 \%$

$0.46 \%$

$0.46 \%$

$0.46 \%$

$0.46 \%$

$0.46 \%$

$0.46 \%$

$0.46 \%$

$0.46 \%$

$0.46 \%$

$0.46 \%$

$0.46 \%$

$0.46 \%$

$0.46 \%$

$0.46 \%$

$0.46 \%$

$0.46 \%$

$0.46 \%$

$0.46 \%$

$0.46 \%$

$0.14 \%$

$0.11 \%$

$0.33 \%$

$0.46 \%$

$0.46 \%$

$0.46 \%$

$0.46 \%$

$0.46 \%$

$0.46 \%$

$-0.02 \%$

$0.46 \%$

$-0.06 \%$

$0.46 \%$

$0.46 \%$
$0.06 \%$

$0.06 \%$

$0.57 \%$

$0.51 \%$

$0.53 \%$

$0.52 \%$

$0.56 \%$

$0.51 \%$

$0.51 \%$

$0.52 \%$

$0.06 \%$

$0.07 \%$

$0.06 \%$

$0.53 \%$

$0.52 \%$

$0.06 \%$

$0.06 \%$

$0.57 \%$

$0.51 \%$

$0.06 \%$

$0.68 \%$

$0.49 \%$

$0.06 \%$

$0.06 \%$

$0.53 \%$

$0.52 \%$

$0.06 \%$

$0.07 \%$

$0.50 \%$

$0.52 \%$

$0.06 \%$

$0.06 \%$

$0.06 \%$

$0.06 \%$

$0.06 \% \quad 0.07 \%$

$0.06 \%$

$0.06 \%$

$0.06 \%$

$0.06 \%$

$0.06 \%$

$0.06 \%$

$0.06 \%$

$0.06 \%$

$0.05 \%$

$0.06 \%$

$0.06 \%$

$0.06 \%$

$0.06 \%$

$0.07 \%$

$0.06 \% \quad 0.07 \%$

$0.06 \%$

$0.06 \%$

$0.06 \%$

$0.06 \%$

$0.06 \%$

$0.07 \%$

$0.06 \% \quad 0.07 \%$

$0.06 \% \quad 0.07 \%$

$0.06 \% \quad 0.07 \%$

$0.06 \% \quad 0.07 \%$

$0.06 \% \quad 0.06 \%$

$0.59 \%$

$0.51 \%$

$0.56 \%$

$0.51 \%$

$0.54 \%$

$0.52 \%$

$0.57 \%$

$0.51 \%$

$0.54 \%$

$0.51 \%$

$0.62 \%$

$0.51 \%$

$0.54 \%$

$0.51 \%$

$0.68 \%$

$0.49 \%$

$0.56 \%$

$0.51 \%$

$0.49 \%$

$0.52 \%$

$0.51 \%$

$0.52 \%$

$0.50 \%$

$0.52 \%$

$0.54 \%$

$0.52 \%$

$0.52 \%$

$0.52 \%$

$0.49 \%$

$0.52 \%$

$0.50 \%$

$0.52 \%$

$0.49 \%$

$0.52 \%$

$0.54 \%$

$0.52 \%$

$0.52 \%$

$0.52 \%$

$0.06 \% \quad 0.07 \%$

$0.52 \%$

$0.52 \%$

$0.06 \% \quad 0.07 \%$

$0.06 \% \quad 0.07 \%$

$0.48 \%$

$0.52 \%$

$0.46 \%$

$0.52 \%$

$0.00 \% \quad 0.00 \%$

$0.16 \%$

$0.16 \%$

$0.08 \%$

$0.08 \%$

$-0.04 \% \quad-0.04 \%$

$0.18 \%$

$0.18 \%$

$0.06 \% \quad 0.06 \%$

$0.06 \% \quad 0.06 \%$

$0.55 \%$

$0.52 \%$

$0.57 \%$

$0.51 \%$

$0.06 \% \quad 0.06 \%$

$0.06 \% \quad 0.07 \%$

$0.58 \%$

$0.51 \%$

$0.50 \%$

$0.52 \%$

$0.06 \% \quad 0.07 \%$

$0.50 \%$

$0.52 \%$

$0.06 \%$

$0.07 \%$

$-0.14 \%-0.15 \%$

$0.05 \% \quad 0.06 \%$

$-0.21 \%-0.21 \%$

$0.06 \% \quad 0.06 \%$

$0.06 \% \quad 0.07 \%$
$0.52 \%$

$0.52 \%$

$-0.16 \%$

$-0.16 \%$

$0.67 \%$

$0.50 \%$

$-0.23 \%$

$0.55 \%$

$0.51 \%$

$0.46 \%$
$-0.23 \%$ 
Ulm. Universitaetsstadt. Kreisfreie Stadt

Unna. Kreis

Unstrut-Hainich-Kreis

Unterallgaeu. Landkreis

USA

Vechta. Landkreis

Verden. Landkreis

Viersen. Kreis

Vogelsbergkreis

Vogtlandkreis

Vulkaneifel. Landkreis

Waldeck-Frankenberg.

Landkreis

Waldshut. Landkreis

Warendorf. Kreis

Wartburgkreis

Weiden i.d.OPf.

Weilheim-Schongau.

Landkreis

Weimar. Krsfr. Stadt

Weimarer Land. Kreis

Weissenburg-

Gunzenhausen. Landkreis

Werra-Meissner-Kreis

Wesel. Kreis

Wesermarsch. Landkreis

Westerwaldkreis

Wetteraukreis

Wiesbaden. Kreisfreie Stadt

Wilhelmshaven. Kreisfreie

Stadt

Wittenberg. Landkreis

Wittmund. Landkreis

Wolfenbuettel. Landkreis

Wolfsburg. Kreisfreie Stadt

Worms. Kreisfreie Stadt

Wuerzburg

Wuerzburg. Landkreis

Wunsiedel i.Fichtelgebirge.

Landkreis

Wuppertal. Kreisfreie Stadt

Zollernalbkreis

Zweibruecken. Kreisfreie

Stadt

Zwickau. Landkreis

\begin{tabular}{|c|c|c|c|c|c|c|c|c|}
\hline $6 \%$ & $\%$ & $\%$ & $\%$ & $\%$ & $\%$ & $\%$ & $\%$ & 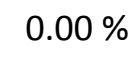 \\
\hline . & T. & . & & 0 & & $44 \%$ & $48 \%$ & te \\
\hline 60 & $16 \%$ & $\%$ & & & & & & 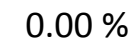 \\
\hline & & & & & & & & \\
\hline & & & & & & & & \\
\hline & & & & & & & & \\
\hline & & & & & & & $5 \%$ & 年 \\
\hline & & & & & & & & \\
\hline & & & & & & & & \\
\hline 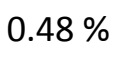 & & & & & & & & \\
\hline & & & & & & & & \\
\hline $49 \%$ & 16 & & & & & & & \\
\hline 50 & 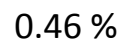 & & & & & & & \\
\hline $51 \%$ & $\Delta \mathrm{f}$ & $\%$ & $\%$ & $\%$ & & & & \\
\hline & & & & & & & & \\
\hline 40 & 46 & $06 \%$ & $\%$ & $45 \%$ & & & & \\
\hline $54 \%$ & $16 \%$ & $0.06 \%$ & & & & & & \\
\hline 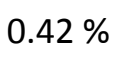 & & & & & & & & \\
\hline $47 \%$ & & $.06 \%$ & & & & & & \\
\hline 1 & & 年 & & & & & & \\
\hline & & & & & & & & \\
\hline C & $\%$ & $\%$ & $\%$ & & & & & \\
\hline 50 & & & & & & & & \\
\hline & & & & & & & & \\
\hline$\%$ & & & & & & & & \\
\hline $40 \%$ & & & & & & & & \\
\hline $46 \%$ & & & & & & & & \\
\hline & & & & & & & & \\
\hline & & & & & & & & \\
\hline $47 \%$ & & & & & & & & \\
\hline & & & & & & & & \\
\hline $51 \%$ & & & & & & & & \\
\hline & & & & & & & & \\
\hline $00 \%$ & 16 & $06 \%$ & $07 \%$ & $40 \%$ & & $20 \%$ & $\%$ & 40 \\
\hline & & & & & & & & \\
\hline & & & & & & & & \\
\hline $53 \%$ & & & & & & & & 7 \\
\hline 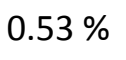 & & & & & & & & 0.10 \\
\hline 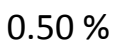 & 政 & & & & & & & .1 \\
\hline
\end{tabular}

